\title{
INDICADORES DE QUALIDADE DE SOLO E ÁGUA PARA A AVALIAÇÃO DO USO SUSTENTÁVEL DA MICROBACIA HIDROGRÁFICA DO RIO PASSO CUE, REGIÃO OESTE DO ESTADO DO PARANÁ
}

\section{HUDSON CARLOS LISSONI LEONARDO}

Dissertação apresentada à Escola Superior de Agricultura "Luiz de Queiroz", Universidade de São Paulo, para obtenção do título de Mestre em Recursos Florestais, com opção em Conservação de Ecossistemas Florestais.

P I R A C I C A B A

Estado de São Paulo - Brasil

Agosto - 2003 


\section{INDICADORES DE QUALIDADE DE SOLO E ÁGUA PARA A AVALIAÇÃO DO USO SUSTENTÁVEL DA MICROBACIA HIDROGRÁFICA DO RIO PASSO CUE, REGIÃO OESTE DO ESTADO DO PARANÁ}

\section{HUDSON CARLOS LISSONI LEONARDO}

Engenheiro Agrônomo

Orientador: Prof. Dr. WALTER DE PAULA LIMA

Dissertação apresentada à Escola Superior de Agricultura "Luiz de Queiroz", Universidade de São Paulo, para obtenção do título de Mestre em Recursos Florestais, com opção em Conservação de Ecossistemas Florestais.

P I R A C I C A B A

Estado de São Paulo - Brasil

Agosto - 2003 


\section{Dados Internacionais de Catalogação na Publicação (CIP) DIVISÃO DE BIBLIOTECA E DOCUMENTAÇÃO - ESALQ/USP}

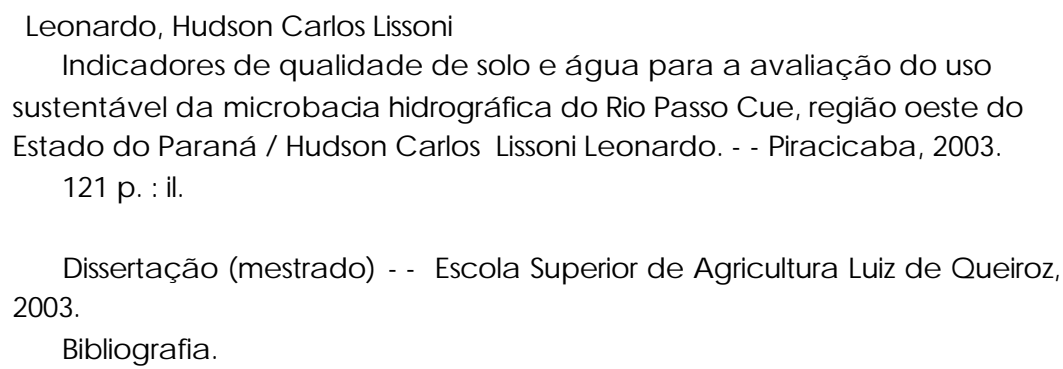

1. Agric ultura sustentável 2. Bacia hidrográfica 3. Ecologia agnícola 4. Física do solo 5. Microbiologia do solo 6. Proteção ambiental 7. Qualida de da água 8. Química do solo 9. Recursosnatura is (conservação) 10. Uso do solo (qualidade) I. Título

CDD 634.9 


\section{CALMA}

A calma é a solução.

Não te esforces demais nem lutes desesperadamente, para resolver um problema.

Acalma-te. Lembra que nas mãos de Deus estão soluções em que jamais pensaste, e que o primeiro passo para alcançá-las é a calma.

Trabalha para melhorar a tua vida e a dos outros, esforça-te, luta com vontade, mas não penses que, forçando exageradamente ou te revoltando e agredindo, estás no melhor caminho. O melhor caminho é a permanência na paz, a segurança em si mesmo, a boa intenção e a fé em Deus.

Administra-te bem.

Quanto mais bem administrada é a empresa, menos problemas tem.

(Lourival Lopes, ÂNIMO)

OFEREÇO

À minha maravilhosa família que sempre me amparou, me amou, me incentivou..., me fortaleceu e não me deixou cair nos momentos mais dificeis de serem superados.

DEDICO

Ao Meu Pai Paulo e à minha Mãe Jacilda, Guerreiros da paz, do carinho e do amor.

Meus ídolos desta vida, exemplos de amor, bondade, carinho, humildade, doçura e de força. 


\section{AGRADECIMENTOS}

Agradeço a todos que possibilitaram a realização deste trabalho.

Ao Prof. Dr. Walter de Paula Lima, pela orientação, oportunidade de aprendizado na área de manejo de microbacias, mas acima de tudo pela amizade, incentivo e compreensão sempre presentes em todos os momentos de diálogo. Obrigado!

À Profa. Maria José de Brito Zakia (Zezé) pelas contribuições sugeridas no decorrer do trabalho, pela amizade e convívio alegre.

Ao Prof. Ademir de Lucas pela grande oportunidade de trabalhar na área de extensão rural, pelas suas importantes contribuições na concepção inicial deste trabalho, mas acima de tudo pela amizade e incentivo desde o início da graduação.

Ao Prof. Leonardo pelo apoio e auxílio em importante etapa deste trabalho.

Ao Professor da UFG Luiz Maurício Bini, pela fundamental ajuda nas análises estatísticas e importantes contribuições.... pela sua enorme disposição em auxiliar-me de forma muito amigável... o meu Muito Obrigado!!

Ao Fernando Ferraz pelas contribuições que deu a este trabalho.

Aos demais professores da ESALQ, pelo ensino agronômico, pela formação profissional, pela amizade e acolhimento nesta querida escola, o meu Muito Obrigado!

À Ana Claudia Lira pela amizade, apoio, disposição em me ajudar e pelas suas importantes contribuições. Também a todos os colegas paraenses pela amizade e apoio durante todo o período em que estivemos juntos em Piracicaba.

Ao Luiz Brandão (Tódi), pela amizade e pela sua disposição em me ajudar.

À Carla Câmara, pela amizade e contribuições que fez no decorrer deste trabalho.

Ao Laboratório de Hidrologia (Zezé, Carla, Fernando, Noemi, Andréa e Paula) pela amizade, colaboração e ajuda.

A todos os colegas da graduação pela amizade, companheirismo e alegrias compartilhadas... em especial ao Solteirão, Tanabi, Lanterna, Sfincter, Badi, Topo e Urbano um grande abraço!! e obrigado pela amizade.

A todos os colegas da Casa do Estudante pela amizade, companheirismo e pelo aprendizado que tivemos juntos.

A todos os colegas do Grupo de Extensão de São Pedro e da Associação de Produtores Agropecuários do Município de São Pedro pela amizade, carisma, pela rica experiência acadêmica, pelo apoio e incentivo que sempre me deram.

Aos amigos e afilhados Veridiana (Pêra) e Leandro (Lê), pela amizade, convívio e apoio, o meu Muito Obrigado!

Ao João Carlos, Kaminski e Berté pela amizade, apoio e incentivo fundamentais para a realização deste trabalho, o meu Muito Obrigado!

Ao Dalmi pela amizade e importantes contribuições e apoio na obtenção de parte dos dados utilizados neste trabalho.

À Simone pela amizade e contribuições com este trabalho.

Ao Luiz e Ari pela amizade e apoio no acondicionamento das amostras de solo.

Aos colegas Dutra, Sergio, Elton, Marcos e João pela amizade recebida desde a minha chegada na Itaipu. Agradeço também a todos os demais colegas de trabalho.

Ao companheiro de campo Edson que muito me ajudou na coleta das amostras.

A todos os colegas ex-trainees pela amizade desde a chegada em Foz. 
À Patrícia, minha esposa querida, minha linda, doce e admirável companheira de todos os momentos, por tudo que tem me ajudado desde os primeiros momentos que nos conhecemos. Obrigado pelo seu amor, carinho, compreensão, apoio, dedicação, muito incentivo (sem o qual este trabalho nem teria iniciado), ânimo, força, conselhos... e pelas suas inúmeras revisões e contribuições fundamentais para que eu pudesse concluir este trabalho. Muito Obrigado!!!

Aos meus pais, Paulo e Jacilda, meus ombros gigantes... do amor, apoio, carinho, afeto e dedicação infinita, pelas constantes palavras de força, pela presença constante mesmo à distância, pelo exemplo de bondade... com esforço incansável e imensurável na criatividade e na arte de costurar, com esta bonita profissão que embeleza as pessoas... construíram com muito amor, carinho e serenidade a obra de Deus na nossa família, um lar de paz e amor, construíram a nossa família maravilhosa. Sem vocês eu jamais conseguiria chegar até aqui!!!

Aos meus irmãos e irmãs, Jeferson (Dé), Aparecido (Cidão), Paulo (Paulinho), Jane e Claudinéa (Néia) por tudo que sempre me apoiaram, me ajudaram, por me acudirem sempre que eu precisei, pelo carinho e dedicação.... Sem vocês eu não teria chegado aqui. A vocês agradeço pela presença constante, amor, apoio, força e incentivo. Às minhas cunhadas e cunhados Karina, Nadir, Rosimeire (Meire), Julio e Daniel pelo carinho, dedicação, apoio, incentivo e por ajudarem a preencher a nossa família com o carinho de vocês. À sobrinhada Lisiane, Daniel, Jaqueline, César, Luciana, Gabriela, Priscila e Bianca por alegrarem a minha vida e pelo carinho com o tio Hudi.

Ao meu Tio Roberto pelo carinho e dedicação que sempre teve comigo e pelo apoio durante minha graduação. Muito Obrigado Tio!!

Aos futuros filhinhos(as) que com a Graça de Deus chegarão no lar.

Pai, nesta nova vida que o senhor vive hoje, que Deus retribua ao senhor todo o amor, luz, paz, brandura, alegria que o senhor sempre nos deu com fartura... continuamos juntos pelo nosso coração e vibração em Deus!!!

Deus, obrigado pela oportunidade da vida, pela realização deste trabalho e pela família maravilhosa que tenho. A tua benção Senhor! 


\section{SUMÁRIO}

Página

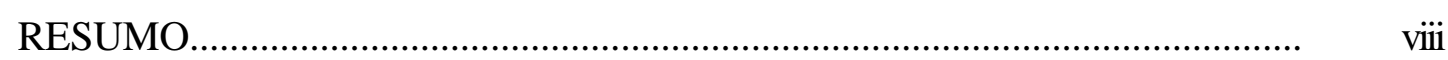

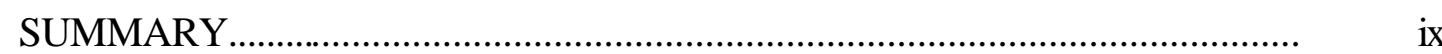

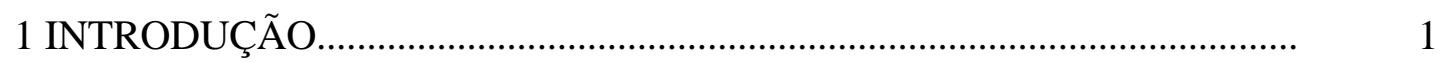

1.1Hipóteses de trabalho.....................................................................................

1.2 Objetivo principal............................................................................................

1.2.1Objetivos específicos................................................................................

2 REVISÃO DE LITERATURA..........................................................................

2.1 Bacia e microbacia hidrográfica...................................................................

2.2 Sustentabilidade, desenvolvimento e agricultura sustentável...........................

2.3 A saúde da microbacia hidrográfica como indicador de mesoescala da sustentabilidade.................................................................................................

2.4 Indicadores de saúde de microbacias hidrográficas........................................

2.4.1 Ecossistema ripário...................................................................................

2.4.2 Qualidade e quantidade de água e regime de vazão em microbacias............ 34

2.4.3 Qualidade do solo 37

3 MATERIAL E MÉTODOS........................................................................... 52

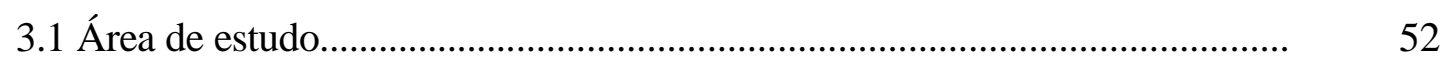

3.2 Componente solo...............................................................................

3.2.1 Procedimento de campo.........................................................................

3.2.1.1 Distribuição das parcelas amostrais..............................................................

3.2.1.2 Coleta de amostras............................................................................

3.2.2 Procedimentos de laboratório......................................................................... 


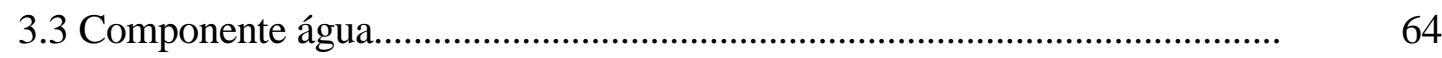

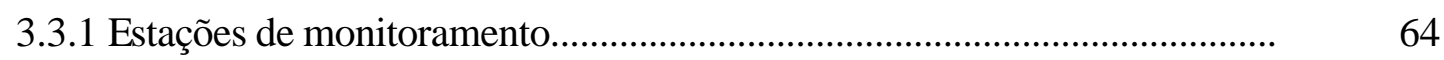

3.3.2 Obtenção dos dados para a avaliação da qualidade da água......................... $\quad 65$

3.4 Análise dos dados...................................................................................

3.4.1 Qualidade do solo..............................................................................

4 RESULTADOS E DISCUSSÃO......................................................................

4.1 Qualidade do solo...................................................................................

4.1.1 Qualidade física..................................................................................

4.1.2 Qualidade biológica...............................................................................

4.1.3 Qualidade física, química e biológica..........................................................

4.2 Qualidade da água.................................................................................

4.2.1 Variáveis físicas e químicas....................................................................

4.2.1.1 Análise de tendência em função do tempo (1996 a 2002), para cada

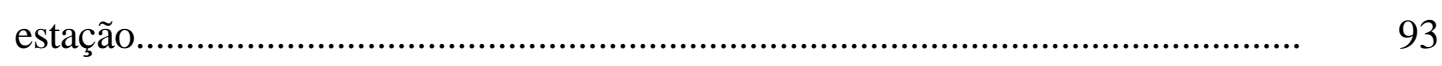

4.2.1.2 Comparação dos dados das variáveis físicas e químicas das duas estações de coleta com os respectivos parâmetros estabelecidos pela resolução $\mathrm{n}^{\circ}$ 20/86 do CONAMA, artigo $5^{\circ}$, que caracteriza as águas doces enquadradas

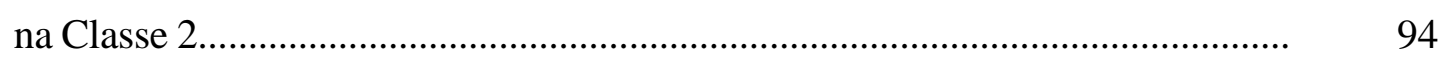

4.2.1.3 Comparação do comportamento das variáveis, físicas, químicas e microbiológicas entre as duas estações de coleta (cabeceira e jusante)................. 105

4.2.2 Índice BMWP' (Biological Monitoring Working Party System) 109

5 CONCLUSÕES..................................................................................... 114

REFERÊNCIAS BIBLIOGRÁFICAS........................................................... 116 


\title{
INDICADORES DE QUALIDADE DE SOLO E ÁGUA PARA A AVALIAÇÃO DO USO SUSTENTÁVEL DA MICROBACIA HIDROGRÁFICA DO RIO PASSO CUE, REGIÃO OESTE DO ESTADO DO PARANÁ
}

\author{
Autor: HUDSON CARLOS LISSONI LEONARDO \\ Orientador: Prof. Dr. WALTER DE PAULA LIMA
}

\section{RESUMO}

O principal objetivo deste estudo foi avaliar a saúde da microbacia hidrográfica do rio Passo Cue, região oeste do estado do Paraná, por meio do uso de indicadores de qualidade de solo e água. Esse rio é afluente da margem esquerda do reservatório de Itaipu e pertence à bacia hidrográfica do Paraná III. Como indicadores de qualidade de água foram utilizadas variáveis físicas, químicas e biológicas. Para avaliação da qualidade do solo, foram analisados os atributos textura, densidade, porosidade, carbono orgânico, biomassa microbiana, respiração basal, quocientes metabólico e microbiano, macro e micronutrientes, $\mathrm{pH}$ e saturação por alumínio. Os indicadores que se mostraram mais eficientes foram a densidade do solo e o quociente metabólico. O solo sob plantio direto apresentou melhor qualidade física, química e biológica em relação ao cultivo mínimo sem rotação de culturas. O solo sob plantio direto apresentou melhor qualidade biológica do que o solo sob fragmento florestal. A qualidade da água na microbacia do rio Passo Cue piorou da montante para a jusante em função do seu uso agropecuário. 


\title{
SOIL AND WATER QUALITY INDICATORS TO EVALUATE THE SUSTAINABLE USE OF THE RIO PASSO CUE WATERSHED IN WESTERN PARANÁ
}

\author{
Author: HUDSON CARLOS LISSONI LEONARDO \\ Adviser: Prof. Dr. WALTER DE PAULA LIMA
}

\section{SUMMARY}

The main purpose of this study was to evaluate the conditions of the Passo Cue river watershed, in western Paraná, through soil and water quality indicators. The river is an affluent of the left bank of the Itaipú reservoir and is a part of the Paraná III watershed. Physical, chemical and biological variables were used as water quality indicators. To evaluate the soil quality, texture, density, porosity, organic carbon, microbial biomass, basal respiration, metabolic and microbial quotients, macro and micronutrients, $\mathrm{pH}$ and aluminum saturation were analyzed. The more efficient indicators were soil density and metabolic quotient. No-tillage soil showed better physical, chemical and biological quality in relationship with the minimum til one with no crop rotation. The soil under no tillage had better biological quality than under forest fragment. The water quality of the Passo Cue river worsened downstream in view of the agricultural use. 


\section{INTRODUÇÃO}

O uso e o manejo da terra, sem uma avaliação prévia das suas potencialidades e limitações, tem sido o motivo da degradação de recursos naturais fundamentais para a sobrevivência do homem, como o solo e a água.

De acordo com Tilman (1999) a produção de alimentos dobrou nos últimos 35 anos, acompanhada de um acréscimo de 6,87 e 3,48 vezes, respectivamente, na taxa anual global de fertilização nitrogenada e fosfatada. Este aumento implicou, ainda, a duplicação da área de terras irrigadas e um aumento de $10 \%$ nas terras cultivadas.

Estima-se que $40 \%$ das terras agrícolas do mundo sofrem degradação (Dumanski $\&$ Pieri, 2000).

Esse cenário ambiental é típico dos países, como o Brasil, que optaram pelo modelo de industrialização da agricultura após a Segunda Guerra Mundial, o qual se implementou pela assim chamada "Revolução Verde", hoje também conhecido como sistema de agricultura convencional.

Um sério problema que a agricultura ainda enfrenta atualmente é a perda de solo por erosão, que tem como conseqüências, além da perda gradativa do potencial produtivo do solo, a degradação dos recursos hídricos.

Segundo Chaves (1999), dentre as causas da erosão estão, o mau uso e manejo do solo, o desmatamento e as queimadas, o uso incorreto dos equipamentos agrícolas, os inadequados projetos hidrológicos das estradas, a inadequação das práticas conservacionistas etc. Embora o assoreamento seja um dos últimos estágios dos problemas de degradação de bacias hidrográficas, no Brasil este ainda é um grave problema a ser solucionado (Chaves, 1999). Esses sedimentos transportados no processo erosivo podem carregar, adsorvidos em seus colóides, íons e moléculas oriundos dos fertilizantes e dos agrotóxicos, que ao se depositarem nas nascentes, nos leitos de rios e 
reservatórios levam ao assoreamento e ou eutrofização destes corpos hídricos com conseqüente perda de qualidade da água (Merten, 1994).

Dumanski \& Pieri (2000), discorrendo sobre os impactos das intervenções humanas nos recursos naturais, afirmam que pela primeira vez a humanidade enfrenta uma situação onde o manejo sustentável dos recursos naturais é mais importante que o suprimento em produtos para o desenvolvimento, tendo em vista que a sobrevivência humana e inclusive, o próprio processo de desenvolvimento, dependem dos recursos naturais. Mas, a degradação ambiental e o manejo equivocado desses recursos estão ameaçando nossas oportunidades e flexibilidades de aumentar os serviços prestados pela natureza; ao contrário, levam ao aumento da demanda em investimentos de conservação de solos e de recuperação de áreas degradadas.

Gliessman (2000) e Altieri (2002) também deixam claro que não só é preciso, mas também perfeitamente possível conciliar produção com a conservação dos recursos naturais dos quais a produção depende.

Com relação à magnitude da questão de degradação de solos e recursos hídricos Dumanski \& Pieri (2000) citam que as estimativas atuais são de que um terço ou metade das terras do globo, que não estão ocupadas por geleiras, são regularmente manejadas e que acima de $70 \%$ delas recebem algum grau de intervenção humana.

Portanto, na busca pela sustentabilidade torna-se cada vez mais imperativa a necessidade do estabelecimento de critérios e metodologias para a avaliação e monitoramento do efeito das atividades humanas sobre o ambiente, buscando, dentre outros aspectos, reorientá-las.

Dentre os diversos usos dos recursos hídricos, destaca-se a geração de energia, em grande parte responsável pelos avanços sociais, econômicos, tecnológicos, científicos de nações, como o Brasil, que exuberantemente dispõe destes recursos.

O reservatório de Itaipu contribui com $25 \%$ da energia consumida no Brasil, sendo um empreendimento crucial para o atendimento das demandas dos diferentes segmentos da sociedade com poder de demanda.

Com esta substancial relevância nacional, medidas de avaliação e monitoramento ambiental com vistas à orientação das ações antrópicas no âmbito das bacias 
hidrográficas de influência sobre o reservatório de Itaipu tornam-se uma constante meta. O subsidio técnico oriundo do monitoramento é fundamental para que se evite a criação de um cenário ambiental caracterizado pelo desequilíbrio de importantes processos hidrológicos de efeito direto sobre os corpos hídricos.

Diante disso e partindo-se da premissa de que a busca do uso agrícola sustentável de microbacias hidrográficas é parte crucial do processo de conservação dos recursos naturais em regiões de vocação tipicamente agrícola, o presente estudo buscou avaliar a saúde de uma microbacia hidrográfica, constituinte de uma sub-bacia drenada por um dos afluentes (rio Passo Cue, município de São Miguel do Iguaçu-PR) da margem esquerda do reservatório de Itaipu, visando contribuir na avaliação da qualidade das práticas agrícolas locais, das quais dependem a qualidade ambiental e o avanço em direção à agricultura sustentável.

\subsection{Hipóteses de trabalho}

a) A comparação entre a qualidade do solo sob cultivo mínimo e sob plantio direto, em comparação com aquela observada sob floresta natural, permitirá avaliar o efeito do tipo de manejo sobre a qualidade do solo;

b) A comparação da qualidade da água de uma das nascentes formadoras do rio Passo Cue com a qualidade da água na jusante da microbacia possibilitará inferir sobre a adequação do uso da terra da microbacia;

c) A análise conjunta dos indicadores de qualidade de solo e água permitirá inferir sobre a saúde da microbacia.

\subsection{Objetivo principal}

Avaliar o efeito do uso da terra sobre a qualidade da água da microbacia hidrográfica do rio Passo Cue, a partir da análise de indicadores de qualidade de solo e de água. 


\subsubsection{Objetivos específicos}

a) Comparar na camada de $0-10 \mathrm{~cm}$ de profundidade a qualidade do solo agrícola em dois sistemas de manejo, isto é, o sistema de cultivo mínimo sem rotação de culturas e o sistema de plantio direto com rotação de culturas, tendo-se como testemunhas o solo sob fragmento florestal;

b) Comparar a qualidade da água de uma das nascentes formadoras do rio Passo Cue com a qualidade da água no final (jusante) desta microbacia, com base em parâmetros químicos, físicos e biológicos.

c) Avaliar a saúde da microbacia do rio Passo Cue a partir da análise dos indicadores de qualidade de solo e água. 


\section{REVISÃO DE LITERATURA}

\subsection{Bacia e microbacia hidrográfica}

Para Odum (1988) a bacia hidrográfica pode ser vista como um sistema aberto, cujo funcionamento e estabilidade relativa refletem, em grande parte, as taxas de influxo e os ciclos de energia, da água e de materiais ao longo do tempo. $\mathrm{O}$ autor cita como exemplo que as causas e as soluções da degradação da água não serão encontradas olhando-se apenas para dentro da água; geralmente é o gerenciamento incorreto da bacia hidrográfica que destrói os recursos hídricos. Portanto, a bacia hidrográfica inteira deve ser a unidade de gerenciamento.

Mello et al. (1994) explicam que se tomando como referencial uma seção transversal de um rio, chama-se bacia hidrográfica ou bacia de contribuição, a área coletora de água proveniente da precipitação que, escoando pela superfície do solo, atinge a seção considerada.

E neste sentido as diferentes definições de microbacia têm sua origem numa interpretação ou na compreensão científica da interação entre as suas funções na paisagem e a sua conformação geomorfológica, considerando-se fundamentalmente cada um dos seus componentes.

Dessa forma, orientando as ações humanas para a busca do uso conservacionista dos recursos naturais, ecologicamente organizados na escala da microbacia hidrográfica, há na literatura diversos enfoques para o tema do presente trabalho, ou seja, o manejo integrado da microbacia hidrográfica. Lima (1999) explica que a microbacia hidrográfica constitui a manifestação bem definida de um sistema natural aberto e pode ser vista como a unidade ecossistêmica da paisagem, em termos de integração dos ciclos naturais de energia, de nutrientes e, principalmente, da água. 
Para Rocha (1991) os conceitos de microbacia e de bacia hidrográfica são os mesmos, ou seja, ambos estão relacionados com aquelas áreas drenadas pelas águas pluviais, as quais, por ravinas, canais e tributários, dirigem-se para um curso principal, com vazão afluente convergindo para uma única saída e desaguando diretamente no mar ou em um grande lago.

Com relação ao fator área na distinção entre os termos bacia e microbacia hidrográfica Lima \& Zakia (2000), explicam que sob o ponto de vista da hidrologia a classificação das bacias hidrográficas em grandes e pequenas deve ser feita com base não somente na sua superfície total, mas também considerando os efeitos de certos fatores dominantes na geração do deflúvio. Assim, hidrologicamente as microbacias tem como características distintas uma grande sensibilidade tanto a chuvas de alta intensidade (curta duração), como também ao fator uso do solo (cobertura vegetal). Quer isso dizer que as alterações na quantidade e na qualidade da água do deflúvio, em função de chuvas intensas e ou em função de mudanças no uso do solo, são detectadas com muito mais sensibilidade nas microbacias do que nas bacias grandes. Nestas últimas, o efeito de armazenamento da água pluvial ao longo dos canais é tão pronunciado que a bacia torna-se menos sensível àqueles dois fatores (chuvas intensas e mudança no uso e ou cobertura do solo).

Essa explicação hidrológica contribui, portanto, de modo fundamental na distinção, definição e principalmente na delimitação espacial de micro e de bacias hidrográficas, sendo a sua compreensão, crucial para a estruturação de programas de monitoramento ambiental. Por meio de instrumentação de medições de variáveis hidrológicas, limnológicas, da topografia e da cartografia e com o auxílio de Sistemas de Informações Geográficas, pode-se chegar a uma adequada delimitação espacial de micro e de bacias hidrográficas.

Um conceito mais recente que vem complementar o entendimento desta diferença entre microbacias e bacias grandes é a noção de escalas de análise da sustentabilidade. Uma importante contribuição desta compreensão é a orientação que dela se obtém para o monitoramento dos impactos ambientais de forma orientada a identificação das causas destes impactos. 
Nessa base conceitual que buscar-se-á apresentar e discutir, a microbacia hidrográfica é um elemento de escala de análise ambiental muito singular, pois ela representa o elo de ligação entre a escala micro (correspondente àquele nível de análise, verificação, medição, monitoramento e intervenção in loco) e a macroescala de análise (correspondente à paisagem, região, bacia hidrográfica, nação ou até mesmo global) de onde são emanadas as normas, a legislação e as políticas públicas.

Nesta abordagem de escalas de análise da sustentabilidade, onde os processos e componentes ecológicos da natureza são tidos como fundamentais (haja vista a definição de bacias e microbacias hidrográficas), a mesoescala de análise da sustentabilidade é a própria escala espacial da microbacia hidrográfica. A microescala, por sua vez, é representada por um nível de avaliação, monitoramento, medição, averiguação etc, que são efetuadas no próprio local (site assessment) onde se encontra o componente ou o processo ecológico/hidrológico que se quer identificar, qualificar e/ou quantificar. Espacialmente, a escala micro ou microescala de análise pode ser representada pelas medições e averiguações nas unidades de manejo, propriedades agrícolas, glebas ou talhões de cultivo ou por medições e averiguações realizadas no deflúvio da foz da microbacia hidrográfica (Walker et al., 1996; Lima, 1999).

Para cada uma das referidas escalas de análise, existem indicadores ambientais e metodologias específicas que vem sendo estudados e apontados pelas pesquisas, cujos critérios para a escolha do indicador ou do conjunto de indicadores dependem de vários fatores, dentre eles o objetivo que se tem em vista. Um conjunto mínimo de indicadores com suas especificidades metodológicas de emprego serão abordados mais adiante.

Tendo em vista que os indicadores ambientais prestam-se, dentre outras finalidades, para avaliar e monitorar as intervenções humanas sobre os recursos naturais, a elaboração e execução de planos de manejo, bem como de programas de monitoramento ambiental, a partir de uma mesma base conceitual, pode-se potencializar o compreendimento das relações de causa e efeito existentes entre as ações antrópicas (causas) e os seus impactos ambientais (efeitos). Os indicadores ambientais são, portanto, parte intrínseca à metodologia a ser empregada para tal finalidade. Portanto, as 
referidas escalas de análise ambiental prestam-se também como escalas de planejamento ambiental.

Para se elaborar uma metodologia de avaliação que incorpore indicadores de sustentabilidade, visando orientar as ações humanas a partir das respostas obtidas com o monitoramento, torna-se imprescindível uma discussão sobre o significado do termo "sustentabilidade". Masera (1999) explica que uma das maiores dificuldades das metodologias de avaliação de sustentabilidade já propostos na literatura é precisamente o desenvolvimento de critérios e indicadores sem uma discussão adequada do conceito de sustentabilidade subjacente.

\subsection{Sustentabilidade, desenvolvimento e agricultura sustentável}

Segundo Masera (1999) um dos maiores desafios enfrentados pela discussão sobre desenvolvimento sustentável - e particularmente àquela que se refere à agricultura sustentável - é a elaboração de metodologias aplicadas que permitam avaliar a sustentabilidade de diferentes projetos, tecnologias ou agroecossistemas em situações concretas. Este desafio tem como uma de suas causas a necessidade de questionamento das formas convencionais de avaliar esses projetos, tecnologias e sistemas de manejo de recursos naturais. Este autor afirma ser impossível estabelecer uma definição universal desses termos, principalmente pela grande diversidade de interesses, problemas, perspectivas e escalas em jogo, que forma um cenário complexo onde se torna difícil obter um consenso. Portanto, mais importante do que a busca por definições universais é identificar e entender os elementos centrais comuns da discussão, de forma que se consiga produzir definições operacionais úteis para problemas concretos e, então, utilizá-las de maneira consistente.

De acordo com Souza (1996) o relatório da Comissão Mundial para o Meio Ambiente e Desenvolvimento - CMMAD, também conhecido como Relatório Brundtland ou Nosso Futuro Comum, define desenvolvimento sustentável como sendo "aquele que atende as necessidades do presente sem comprometer a possibilidade de as gerações futuras atenderem às suas próprias necessidades” . 
Para Souza (1996) esse documento ampliou a discussão sobre desenvolvimento e meio ambiente, na medida em que introduziu parâmetros tais como, sustentabilidade, desenvolvimento, subdesenvolvimento, pobreza, degradação ambiental, solidariedade e compromissos entre nações de diferentes graus de desenvolvimento e entre gerações (atuais e futuras), sendo todos esses aspectos vistos sob um enfoque global.

O presente trabalho tem como diretriz básica a busca da agricultura sustentável, para a qual tem-se como premissa o entendimento do agroecossistema. Gliessman (2000) o explica como sendo um local de produção agrícola, por exemplo, uma propriedade agrícola, entretanto compreendido como um ecossistema. Ainda segundo o autor, examinando os aspectos estruturais dos ecossistemas (suas partes interações mútuas) e remetendo-se aos seus aspectos funcionais, ou seja, como funcionam os ecossistemas, tem-se constituída a base conceitual fundamental para definir um agroecossistema. Assim sendo, os agroecossistemas são descritos em termos de como eles se comparam, estrutural e funcionalmente, com ecossistemas naturais.

Segundo Altieri (2002) alguns aspectos fundamentais dos agroecossistemas envolvem:

- Os agroecossistemas são formados por conjuntos de componentes abióticos e bióticos, ligados intimamente, formando uma unidade ecológica funcional.

- Os agroecossistemas podem ser estabelecidos em limites definidos de maneira que possam auto-regular-se.

- Os agroecossistemas variam de acordo com a natureza de seus componentes, seu arranjo temporal e espacial e em relação ao nível de intervenção humana.

- Nenhum agroecossistema é uma unidade completamente independente e raramente têm limites biológicos bem definidos.

- Os agroecossistemas podem pertencer a qualquer escala biogeográfica.

Com base nesses fundamentos, o autor explica que os elementos básicos de um agroecossistema sustentável são a conservação dos recursos renováveis, a adaptação da espécie cultivada ao ambiente e a manutenção de um elevado e sustentável nível de produtividade. 
Um aspecto fundamental no desenho de agroecossistemas sustentáveis é a compreensão de que duas funções existentes no ecossistema devem estar presentes na agricultura: a biodiversidade dos microorganismos, plantas e animais e a ciclagem biológica de nutrientes da matéria orgânica (Altieri, 2002).

Para desempenhar essas duas funções, os componentes básicos de um agroecossistema sustentável, do ponto de vista do manejo são:

- Cobertura vegetal, como medida eficaz de conservação da água e do solo, através das práticas de cultivo mínimo, uso de cobertura morta, cultivos de cobertura etc.

- Fornecimento contínuo de matéria orgânica pela adição regular de compostos orgânicos (esterco, composto) e promoção da atividade biológica do solo.

- Mecanismos de reciclagem de nutrientes por meio do uso de rotações de culturas, sistemas integrados com vegetais e animais, sistemas agroflorestais, cultivos em faixas com base em leguminosas etc.

- Controle de pragas devido ao aumento da atividade biológica dos agentes de controle, alcançado pelo manejo da biodiversidade, introduzindo e ou conservando os inimigos naturais.

Altieri (2002) explica que a principal estratégia da agricultura sustentável é a de reconstituir a diversidade agrícola no tempo e no espaço, por meio das rotações de culturas, policultivos, cultivos de cobertura, integração entre vegetais e animais etc (Figura 1). 


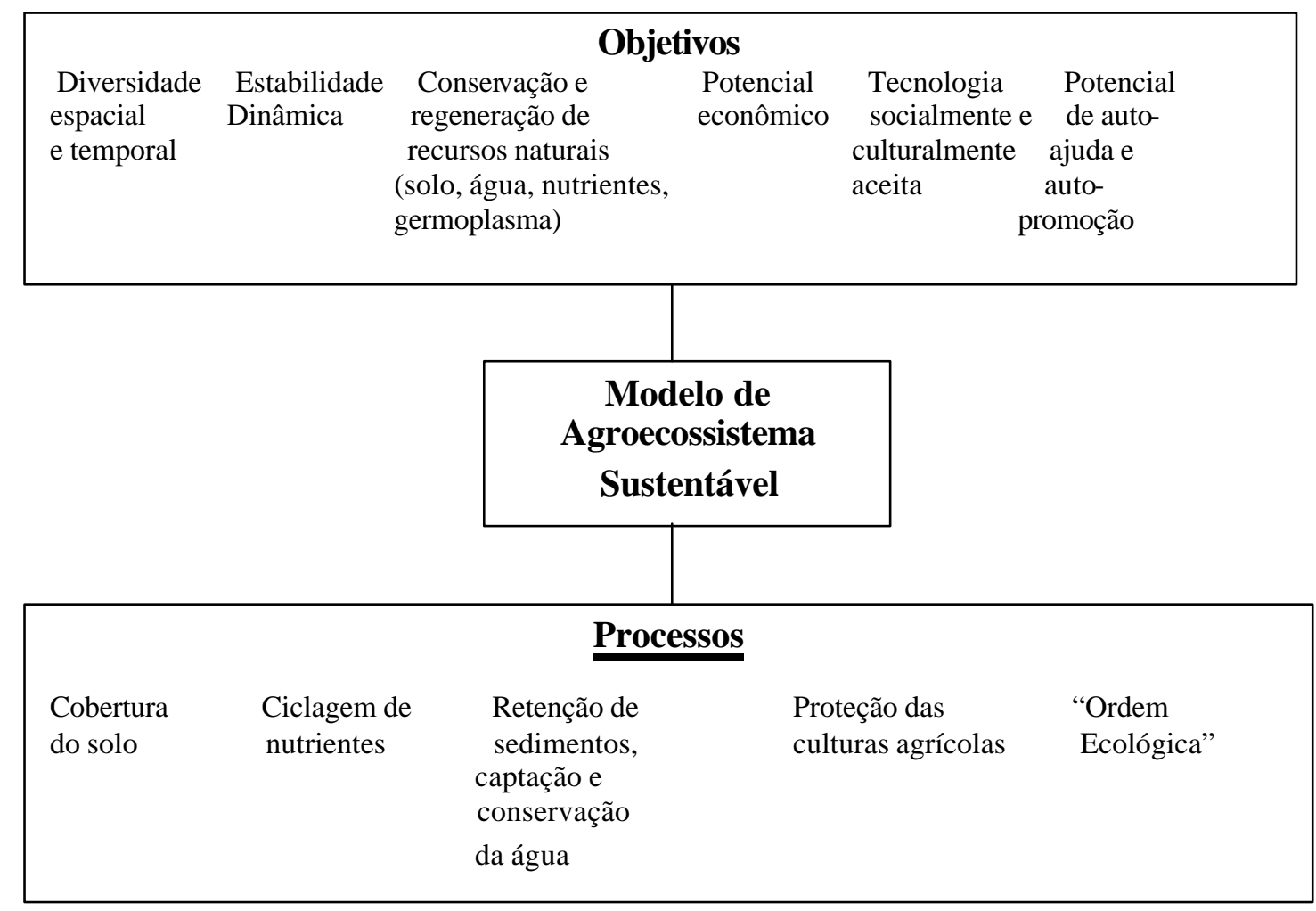

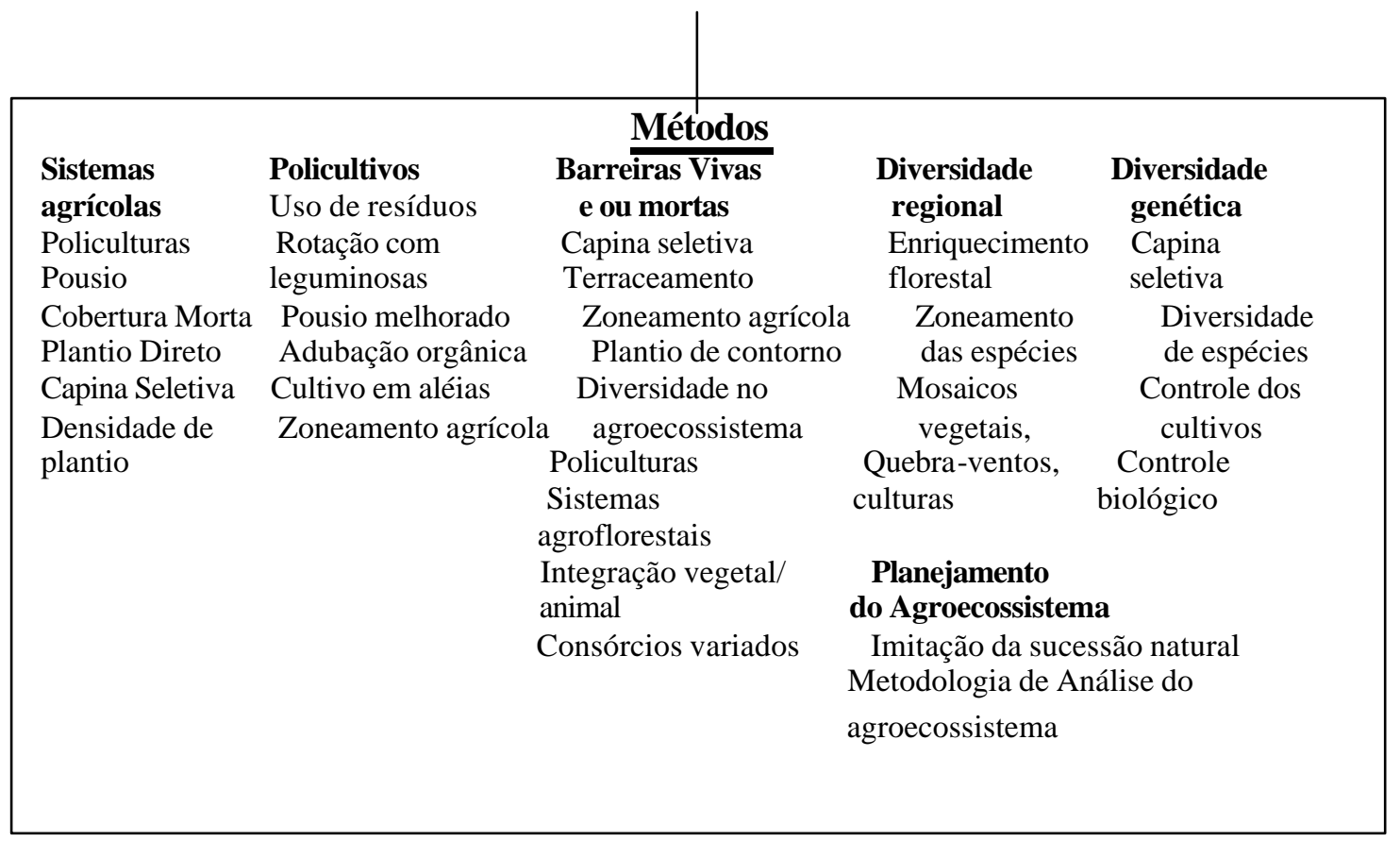

Figura 1 - Objetivos e processos no planejamento de um agroecossistema sustentável (Altieri, 2002) 
Hansen (1996) caracteriza diversos tipos de definições para a agricultura sustentável referindo-se aos pontos de vista de uma ideologia, de um conjunto de estratégias, da possibilidade para satisfazer certas metas ou como a habilidade de manter certas propriedades ao longo do tempo. No seu estudo, dentre outras conclusões, o autor afirma que, embora haja consenso na literatura sobre a importância do conceito de sustentabilidade para a agricultura, os critérios para se avaliar as respostas dos sistemas produtivos às mudanças orientadas para a sustentabilidade ainda não estão esclarecidos.

Mais recentemente, convergindo com essa opinião, Gliessman (2000) explica que dentre as várias interpretações de sustentabilidade, concordância há de que ela tem uma base ecológica. Para esse autor, a sustentabilidade é a condição onde é possível a produção sustentável, ou seja, a possibilidade de perpetuamente colher biomassa de um sistema, porque sua capacidade de se renovar ou ser renovado não é comprometida. Nessa visão, o autor afirma que com o conhecimento científico atual é impossível se saber com certeza se uma determinada prática de manejo é ou não sustentável. Entretanto, conclui dizendo que é possível demonstrar que uma prática está se afastando da sustentabilidade.

As concepções sobre sustentabilidade, desta forma, são várias e, da explicação de Masera (1999) pode-se compreender que em cada concepção estará implícita o contexto social, cultural, econômico, ambiental, acadêmico e produtivo que a influenciou. O autor, em seu trabalho de proposição de um Método para a Avaliação de Sistemas de Manejo de Recursos Naturais (MESMIS), identifica claramente os elementos centrais convergentes na discussão sobre sustentabilidade e desenvolvimento sustentável: i) o melhoramento e a conservação da fertilidade e da produtividade dos solos, com estratégias de manejo de baixo uso de insumos e custo reduzido; ii) a satisfação das necessidades humanas; iii) a viabilidade econômica; iv) a aceitabilidade social (equidade e melhoria da qualidade de vida dos agricultores e da sociedade); v) adequação ecológica (minimização de impactos, proteção e melhoramento do ambiente); vi) durabilidade do sistema em longo prazo, ao invés de rentabilidade no curto prazo. Este último aspecto é enfatizado também por Altieri (2002), explicando ser isto possível quando se substitui a lógica da maximização produtiva no curto prazo (às custas de altos 
inputs energéticos), pela lógica da busca da eficiência biológica do sistema. Altieri (2002) se refere à agricultura sustentável como sendo um modo de agricultura que visa proporcionar rendimentos sustentáveis em longo prazo, por meio do uso de tecnologias e práticas de manejo que melhorem a eficiência biológica do sistema.

Para Conway (1994), a sustentabilidade pode ser definida como a habilidade de um sistema em manter a sua produtividade ainda quando seja submetido a estresses, ou perturbações.

Souza (1996) explica que a Sociedade Americana de Agronomia define a agricultura sustentável como aquela que no longo prazo promove a qualidade do meio ambiente e dos recursos básicos dos quais depende a agricultura, provê as fibras e alimentos necessários para o ser humano, é economicamente viável e melhora a qualidade de vida dos agricultores e da sociedade em conjunto.

Nesse sentido, a orientação é a de otimizar o agroecossistema em seu conjunto, ao invés de se buscar a maximização dos rendimentos no curto prazo.

É importante observar que as informações apresentadas nesta discussão referem-se às bases teóricas que orientam a intervenção, avaliação e monitoramento ambiental em um dos componentes da micro escala da sustentabilidade, ou seja, o agroecossistema, o qual, como já mencionado, pode ser representado por uma propriedade agrícola, uma gleba de cultivo desta propriedade, ou ainda como uma determinada porção espacial de uma determinada microbacia hidrográfica.

A avaliação e o monitoramento da qualidade do solo (por meio de atributos indicadores), ao nível das glebas de manejo, ou ao nível da propriedade agrícola, representa, portanto, a análise da escala micro da sustentabilidade, pois está se fazendo medições e averiguações no próprio componente ecológico que se quer qualificar, neste caso, o solo.

As informações obtidas pela avaliação e monitoramento da qualidade do solo (utilizando-se atributos indicadores da parte física, química e biológica do solo), no âmbito de uma gleba de cultivo ou de uma porção espacial da microbacia, constituem-se portanto em um indicador da microescala da sustentabilidade. 


\subsection{A saúde da microbacia hidrográfica como indicador de mesoescala da sustentabilidade}

Para esta discussão parte-se do entendimento de que a microbacia como um todo deve estar saudável quando se quer buscar a sustentabilidade. Focando-se aqui para os indicadores ambientais pertinentes a esta escala de análise, ou seja, pertinentes à escala da microbacia hidrográfica (mesoescala).

O conceito de saúde vem sendo introduzido no contexto ambiental como uma extrapolação criteriosa da sua origem, ou seja, na área da medicina humana. Assim como nesta última, na área ambiental o conceito em si, bem como a metodologia e seus componentes, utilizados para se avaliar o estado de saúde ou uma tendência rumo a ele, ainda não estão totalmente esclarecidos (Walker \& Reuter, 1996).

Esse conceito tem sido largamente empregado no âmbito de organizações biológicas e está claro que a sua origem se deu no nível dos indivíduos e de seus componentes, sendo posteriormente difundido para comunidades de indivíduos (medicina populacional, genética, epidemiologia, saúde de comunidades), sistemas sociais (saúde política e econômica) e muito coerentemente foi estendido para o nível de ecossistemas e para o nível de paisagem (Walker \& Reuter, 1996).

Para Walker \& Reuter (1996), em função da grande aplicação e significado intuitivo do termo "saúde", ainda há resistência quanto ao seu emprego. A razão para isso, segundo os autores, é devido à confusão existente entre qualidade "medida objetivamente" e o julgamento "subjetivo", dando a entender que a questão central é a necessidade de se constituir a condição de saúde. Para esses autores essa incerteza também existe na medicina humana, a qual por sua vez reconhece que o julgamento social desempenha uma grande função naquilo que é aceitável.

Apesar desses dilemas, algumas definições já existentes devem ser utilizadas para a orientação da busca de uma condição mais harmônica entre as atividades antrópicas e os componentes bióticos e abióticos dos ecossistemas naturais, dos quais depende a produção agrícola, o suprimento contínuo em água para os seres vivos e logicamente, a sobrevivência humana. 
Uma microbacia hidrográfica saudável é capaz de se restabelecer após sofrer perturbações (Walker et al., 1996).

Como uma referência de comparação para o entendimento do termo saúde, no contexto de microbacias hidrográficas, tem-se o conceito de integridade de uma microbacia. O estado íntegro é condição decorrente da evolução natural do ecossistema, ou seja, é o resultado da integração natural da microbacia na paisagem, ao longo do processo evolutivo. Já a saúde da microbacia deve ser entendida como uma condição viável, um estado sustentável de equilíbrio dinâmico, compatível com a necessidade de uso dos recursos naturais para a produção dos bens que satisfaçam as demandas da sociedade. A saúde é, portanto, mais do que a integridade biofísica da microbacia. Ela abrange a possibilidade de alterar o estado original (integridade), conferindo ao sistema a possibilidade de se manter produtivo ao longo tempo, e de minimizar impactos ambientais (Walker et al., 1996; Lima, 1999).

Ainda segundo os mesmos autores, a inclusão dos valores sociais na definição de saúde de microbacias hidrográficas reflete uma demanda ou um desejo para que a microbacia seja capaz de sustentar:

- Qualidade da água para uso doméstico e reservas;

- Qualidade da água em riachos e rios para sustentar suas funções como ecossistema aquático e a biodiversidade;

- Terras produtivas para sustentar a produção de alimentos e uma renda viável;

- Biodiversidade para sustentar as funções ecológicas no contexto da paisagem;

- Estética ou visão da paisagem que melhora a qualidade de vida.

Num contexto aplicado, ou seja, do ponto de vista de uma comunidade rural, a principal preocupação é com a manutenção ou incremento da produtividade e da utilidade de suas terras. Neste caso, a produtividade agrossilvopastoril é, portanto, o primeiro componente de avaliação da saúde de uma microbacia com tal vocação ou uso. Dessas duas últimas considerações dos autores, segue um raciocínio em cadeia (Walker \& Reuter, 1996): 
- A produtividade é uma medida da condição (estado atual) do sistema, sendo ela neste caso, considerada mais como uma base de retorno econômico. O retorno econômico, por sua vez, (desconsiderando as flutuações de preços dos produtos agrícolas) é em parte determinado pela qualidade do produto;

- A qualidade dos produtos, portanto, é o segundo componente para avaliação da saúde de uma microbacia;

- A produtividade depende de um terceiro componente que é a qualidade do solo, a qual é afetada, acima de tudo, pelas práticas agrícolas;

- O reflexo dos impactos de uso da terra podem ser detectados pela medida de atributos (indicadores) do componente qualidade de água do riacho ou rio que drena a microbacia.

- O quinto e último componente, a integridade da paisagem, reflete a escala da microbacia hidrográfica (escala meso);

Quando se parte para a averiguação da qualidade da água de uma microbacia, da quantidade de sólidos em suspensão e dissolvidos na água, do seu regime de vazão ou outras variáveis limnológicas e hidrológicas, de acordo com os conceitos já apresentados, está se trabalhando na escala micro de análise. Isso porque as medições e/ou observações são realizadas no próprio componente ou processo ecológico/hidrológico que se pretende identificar, qualificar e quantificar, ou seja, tratase de avaliação in loco (site assessment). Neste caso específico, mensuram-se os indicadores de qualidade e de quantidade de água, e, a partir de análises e interpretações criteriosas, obtêm-se informações que retratam a saúde da escala da microbacia hidrográfica, como indicador da mesoescala da sustentabilidade.

Cada um desses componentes (produtividade, qualidade do produto, qualidade do solo, qualidade da água, integridade da paisagem) pode ser descrito em termos de muitos atributos. Estes atributos, por sua vez, podem ser medidos usando-se indicadores específicos apropriados. 
Ressalta-se que a reflexão feita sobre os cinco componentes listados não esgotam a discussão, nem tampouco apresentam todos os componentes possíveis; ao contrário, fornece uma reflexão aplicável a diferentes situações onde tanto os próprios componentes em si, quanto a importância relativa de cada um deles pode ser variável.

De um modo genérico, porém fundamentado, pode-se assim resumir a expressão "saúde" no contexto ambiental:

saúde $=$ condição sustentável ou viável compatível com o uso dos recursos naturais.

De nada adiantaria a compreensão do significado da saúde de um ecossistema, ou no caso em questão, de uma unidade do ecossistema que é a microbacia hidrográfica, se não se dispuser de metodologia e critérios para avaliar o estado saudável ou a tendência (aproximação ou distanciamento) em relação a este estado ou condição.

Considerando o que foi exposto, indicadores de sustentabilidade devem ser utilizados tanto para avaliar o estado atual de uma microbacia em relação a um estado desejável (indicadores de condição), como para monitorar as suas mudanças (como muda e quanto muda) ao longo do tempo (indicadores de tendência).

Como será visto adiante, metodologicamente é preciso primeiramente identificar os indicadores adequados para os objetivos que se tem, se avaliação do estado atual, monitoramento ou ambos. Outro aspecto não menos importante é a identificação dos indicadores com base nas diferentes escalas de análise. Lima (1999) explica que os processos ecológicos determinantes da sustentabilidade operam em diferentes escalas e, portanto, diferentes indicadores devem ser identificados para as diferentes escalas.

Numa discussão onde grande ênfase é dada para os aspectos de avaliações e medições do estado de saúde de um ecossistema, é importante resgatar o dilema ainda existente entre sustentabiliade e desenvolvimento, ou seja: para se buscar sustentabilidade é preciso usar adequadamente os recursos naturais e para saber se isso está ocorrendo é necessário avaliar e monitorar. Ao mesmo tempo é preciso produzir alimentos, fibras e energia para que haja desenvolvimento. 
O monitoramento tem como um de seus produtos principais a reorientação técnica e científica das práticas de uso dos recursos naturais com vistas à busca da sustentabilidade; produzir sob orientação do monitoramento é estrategicamente correto do ponto de vista da busca do que se imagina ser o estado de sustentabilidade. Portanto, o dilema entre o que é mais importante, produzir ou averiguar a adequação do sistema de produção, perde o significado, quando se busca produzir tendo no bojo o conceito de sustentabilidade orientando o monitoramento, que por sua vez orienta as práticas dos sistemas produtivos.

\subsection{Indicadores de saúde de microbacias hidrográficas}

De acordo com Walker et al. (1996), indicadores ambientais são atributos mensuráveis do ambiente que podem ser monitorados via observações de campo, amostragem de campo, sensoriamento remoto, por compilação de dados pré-existentes ou pela combinação desses métodos. Indicadores, assim, são um conjunto complexo de atributos ou medidas que personificam um aspecto particular do componente de interesse.

Os indicadores devem ser vistos como uma ferramenta de informação e podem ser qualquer variável ou componente do ecossistema. O indicador ideal deve ser preciso e exato em descrever uma função particular do ambiente e servir para assinalar mudanças desejáveis ou indesejáveis que tenham ocorrido, ou que possam ocorrer no futuro (Walker et al., 1996). Estes autores ainda explicam que os indicadores não devem ser entendidos como um conjunto completo de parâmetros ou variáveis que possam ser usados em um processo baseado em modelagem. Eles devem ser entendidos, preferencialmente, como atributos chaves que dão uma impressão das principais tendências e condições, e são baseados em componentes chaves da função do agroecossistema.

A categorização de indicadores pode ser encontrada de modo diverso na literatura.

Walker \& Reuter (1996) identificam ainda, três tipos de indicadores:

- Indicadores de concordância os quais avaliam desvios a partir de condições 
previamente definidas ou a partir de limites aceitáveis;

- Indicadores de diagnósticos os quais identificam a causa dos desvios a partir desses mesmos limites aceitáveis;

- Indicadores de prevenção ou preventivos os quais assinalam tendências declinantes de determinadas condições.

Jenkins \& Sanders (1992) converteram os indicadores de concordância e os indicadores diagnósticos dentro de três séries de especificidade ou de detalhamento, subdividindo-os, com base na resposta a ser obtida pelo seu uso no monitoramento:

- Série 1: Existe um problema?

- Série 2: Que tipo de problema é este?

- Série 3: Qual é a causa específica do problema?

Segundo Jenkins \& Sanders (1992) "a partir de diferentes tipos de indicadores, se encontram diferentes respostas para diferentes questões em diferentes escalas de análise e em diferentes níveis de complexidade”.

Sendo assim essa subdivisão é importante do ponto de vista metodológico, porque orienta o processo de avaliação e monitoramento da qualidade dos recursos naturais. Conseqüentemente, orienta a elaboração de planos de intervenção ou de manejo, ou ainda subsidia as possíveis reorientações dos planos de manejo em execução.

Walker et al. (1996), a partir de um conjunto de onze critérios de escolha de indicadores, identificaram três conjuntos para situações e objetivos diferentes.

- Indicadores de condição, destinados a avaliar o estado de um sistema ou componente natural, comparativamente a uma condição desejada. Nesse conjunto os autores propõem oito indicadores para a escala micro e dois para a escala meso. Uma importante observação sobre esses indicadores é que não são esperadas grandes variações nos seus valores entre um período de um ano. Por isso a recomendação para a frequiência de amostragem é para períodos que variam entre 2 (dois) e 5 (cinco) anos.

- Indicadores de tendência biofísica são usados para monitorar mudanças biofísicas no curto prazo (como e quanto muda o que se está monitorando). São propostos pelos autores cinco indicadores para a escala micro e cinco para a escala meso. Para esses indicadores, é esperada uma variação sazonal de seus valores e, deste 
modo, a frequiência de amostragem deve ser conduzida pelo menos duas vezes por ano.

- Indicadores de produtividade agrícola, desempenho financeiro e qualidade dos produtos. Neste caso, nove indicadores foram apontados, sendo que estes são obtidos a partir dos dados históricos do próprio agricultor, pela assistência técnica, compradores dos produtos etc.

Os autores explicam ainda que para se avaliar a saúde de uma microbacia é necessário considerar as informações da micro e da meso escala da sustentabilidade. Sendo assim, os indicadores de tendência e condição foram subdivididos em indicadores de escala micro e indicadores de escala meso. Nesse respeito, a partir de Walker et al. (1996) e de Lima (1999), chega-se a seguinte subdivisão dos indicadores de micro e de meso escala de análise da sustentabilidade.

- Indicadores da propriedade agrícola, gleba ou talhão de manejo os quais são principalmente atributos da saúde do solo. Esses indicadores são adequados para o mapeamento da distribuição espacial dos valores desses atributos. No entanto, os valores médios, em muitos casos, têm pouco significado ao se considerar a interpretação conjunta das informações das diferentes escalas em questão.

- Indicadores da microbacia hidrográfica os quase são atributos que integram as respostas de toda a microbacia. Esses indicadores oferecem uma resposta global, ou uma resposta que possibilita fazer inferências sobre a saúde da microbacia, mas não indicam o local de ação imediata ("hot-spots"), isto é, as áreas críticas, para onde devam se fazer as reorientações, por exemplo, no manejo. Enquadram-se nesta categoria, a condutividade elétrica da água, a área total da microbacia coberta por florestas, a condição do ecossistema ripário, a adequação hidrológica do sistema viário entre outros.

Remetendo-se ao conceito de escalas já discutido, em ambos os casos acima, ou seja, tanto no emprego dos indicadores da propriedade agrícola, quanto no emprego dos indicadores da microbacia hidrográfica, busca-se fazer a análise da micro e da meso escala da sustentabilidade, conforme se pode resumir na Tabela 1.

A Figura 2 apresenta os passos fundamentais para a implementação de um programa de monitoramento com o uso de indicadores. 


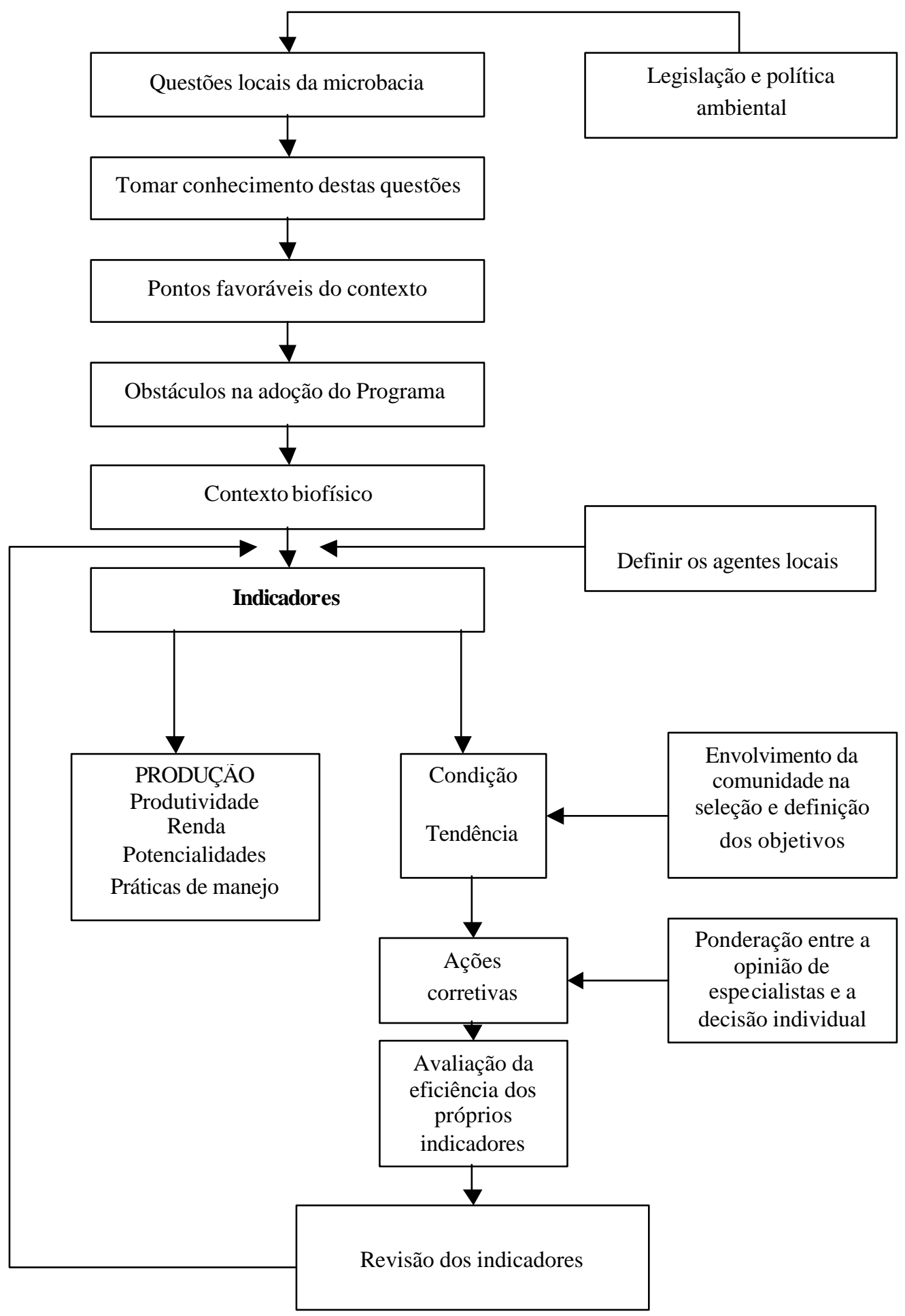

Figura 2 - Passos necessários para um programa de monitoramento (Wlaker et al., 1996) 
Tabela 1. Escalas e indicadores hidrológicos para a proteção do solo e da água visando a busca da agricultura sustentável (Apud., Lima, 1999)

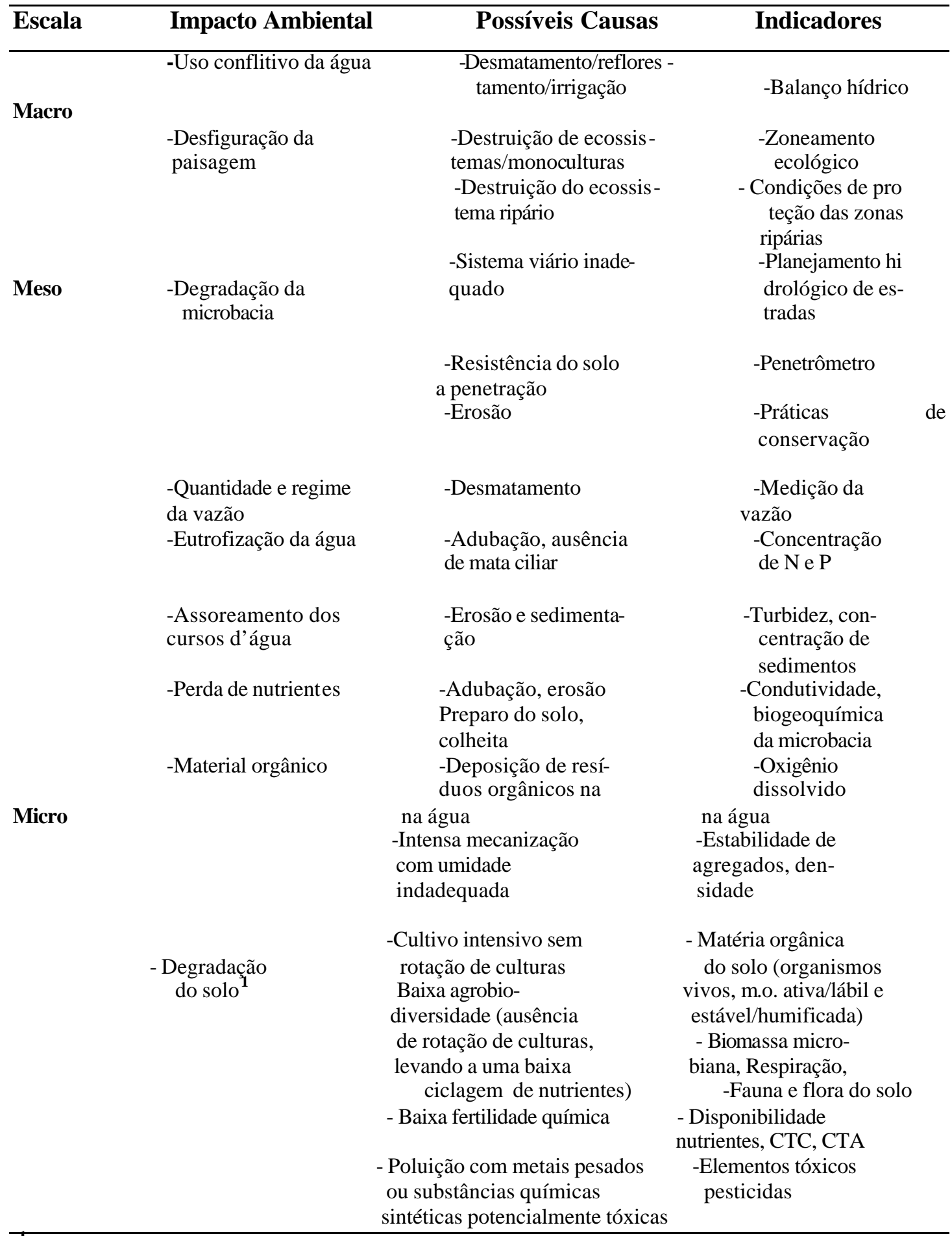

${ }^{1}$ A partir de Altieri (2002) 
A especificação de cada indicador dentro desses três conjuntos (condição, tendência e performance produtiva) abrangendo tanto aqueles de escala micro quanto os de escala meso, é apresentada na Tabela 2.

Tabela 2. Indicadores chaves propostos para avaliação da saúde de microbacias (Walker \& Reuter, 1996)

\begin{tabular}{|c|c|c|}
\hline Condição biofísica & Tendência biofísica & $\begin{array}{c}\text { Produtividade, desempenho } \\
\text { financeiro, qualidade dos } \\
\text { produtos }\end{array}$ \\
\hline Consistência do solo & \% de solo exposto & Produção real / Produção \\
\hline Textura do solo & Profundidade efetiva do & Potencial $(\%)$ \\
\hline Cor do solo & sistema radicular & Precipitação efetiva \\
\hline Taxa de infiltração de água no solo & $\mathrm{pH}$ do solo & Produção de madeira \\
\hline Resistência do solo àpenetração & Condutividade elétrica do & Retorno econômico líquido / ha \\
\hline Agregação e dispersão do solo & solo & Farm business profit/há \\
\hline$\%$ de cobertura arbórea & $\%$ de infestação por ervas & Concentração de proteína nos \\
\hline Condutividade elétrica da água & espontâneas & grãos \\
\hline Análise da fertilidade do solo & pH do curso d’água & Concentração de óleo nos grãos \\
\hline (Nitrogênio total, Fósforo total, & Condutividade elétrica do & \% de proteína e lipídeos no leite \\
\hline Potássio trocável, micronutrientes). & curso d’água & \\
\hline & Turbidez & \\
\hline & Macro-invertebrados & \\
\hline & $\begin{array}{l}\text { Profundidade do lençol } \\
\text { freático }\end{array}$ & \\
\hline
\end{tabular}

O Plano de Ação do Banco Mundial, "Da Visão à Ação no Setor Rural" (Dumanski \& Pieri, 2000) ilustra que a principal demanda em nível nacional e global para o aumento e intensificação da produção agrícola é a busca por Indicadores de Qualidade dos Recursos Naturais (Land Quality Indicators, LOI) que permitam medir e avaliar o progresso rumo a essas metas de incremento produtivo, com base no manejo sustentável. De fato, para esses autores, indicadores são instrumentos comuns para monitoramento de progressos rumo a algum grande objetivo, no caso o manejo sustentável ou a sustentabilidade. É importante ressaltar que no significado da expressão 
"Land", neste caso, estão inclusos além do solo, as formas do relevo, o clima, a hidrologia, a flora e a fauna e ainda as benfeitorias agregadas pelo homem aos ecossistemas manejados, como terraços, sistemas de drenagem etc.

Esse referido Programa identificou as principais lacunas do conhecimento sobre os impactos das intervenções humanas no ambiente, o que resultou na definição do seu Plano de Pesquisa de LQIs, podendo ser estas lacunas relacionadas nos seguintes itens:

- Compreensão da relação entre qualidade dos recursos naturais e pobreza;

- Compreensão da relação entre qualidade dos recursos naturais e o manejo desses recursos, isto é, das práticas de manejo atualmente usadas pelos agricultores;

- Informações georeferenciadas sobre o manejo dos recursos naturais;

- Séries históricas de dados e de informações sobre a resiliência dos sistemas;

- Interação (informação) entre o manejo dos recursos naturais urbano-rurais e planejamento de uso da terra;

- Impactos das macro-políticas sobre as decisões dos usuários dos recursos naturais e sobre a qualidade desses mesmos recursos.

As três primeiras questões foram classificadas pelos especialistas envolvidos no citado Programa como prioritárias, constituindo-se, dessa forma, na base de elaboração do Plano de Pesquisa LQI, o qual em função desses resultados teve como objetivo principal: "Identificar e testar relações de causa-efeito entre qualidade dos recursos naturais, manejo desses recursos e pobreza".

A partir dos fóruns de discussão entre especialistas mundialmente conceituados, o Programa LQI identificou um número mínimo de indicadores, sendo que as principais características desses indicadores são:

- Devem ser passíveis de mensuração no espaço, isto é, ao longo da paisagem e em todos os países;

- Devem ser sensíveis a mudanças em períodos de tempo reconhecíveis (5 a 10 anos);

- Eles se constituem numa função de variáveis independentes;

- Eles são quantificáveis e geralmente adimensionais (estimativas de taxas). 
Dessa forma os indicadores apontados pelo Programa LQI são:

- Balanço de Nutrientes e perda de nutrientes

- Produtividade

- Diversidade e Intensidade de uso dos recursos naturais na agricultura

- Cobertura do solo

- Qualidade do solo

- Degradação do solo

- Agro-biodiversidade

- Qualidade da água

- Qualidade dos recursos florestais

- Qualidade de pastagens

- Poluição e contaminação do solo

Conforme discutido anteriormente, quanto ao conceito de escalas, esses indicadores podem ser agrupados segundo as diferentes escalas da sustentabilidade, informando sobre a condição ou tendência em cada uma delas. Ainda, cada um desses indicadores pode ser avaliado e ou monitorado por meio de seus atributos indicadores chaves, ou simplesmente indicadores chaves. Nesse respeito, a qualidade do solo é um indicador de um dos componentes da microescala da sustentabilidade, podendo ser avaliada por meio dos atributos indicadores chaves do solo, ou seja, indicadores físicos, químicos, biológicos, bioquímicos.

Lima (1999) descreve alguns atributos e indicadores que orientam o manejo sustentável de microbacias hidrográficas, tendo como orientação o conceito de saúde da microbacia.

Segundo esses preceitos, a saúde da microbacia pode ser avaliada em relação a sua capacidade de sustentar pelo menos os seguintes atributos ou indicadores (Lima, 1999):

a) Processos Hidrológicos: regime de vazão, quantidade e qualidade de água

b) Biogeoquímica: indicador da manutenção do seu potencial produtivo ao longo do tempo, ou seja, indicador da manutenção da capacidade de suporte do solo. 
c) Biodiversidade ao longo da paisagem, levando em conta as condições da mata ciliar, das zonas ripárias e a distribuição das reservas de vegetação natural, os quais estão relacionados com a resiliência e estabilidade da microbacia.

Para Prabhu et al. (1996) os critérios e indicadores estão contidos em cinco princípios gerais de sustentabilidade, relacionados com questões relativas à política e legislação, à ecologia, ao aspecto social, e ao manejo propriamente dito. Tais princípios são:

(i) Política, legislação, planejamento e infra-estrutura institucional;

(ii) Manutenção da integridade do ecossistema;

(iii) Plano de manejo;

(iv) Aspectos sociais;

(v) Monitoramento.

O terceiro princípio refere-se à elaboração de planos de manejo, etapa fundamental no processo de intervenção com vistas à conservação dos recursos naturais, seja na agricultura, na pecuária ou na silvicultura. Para essa afirmação, é importante o entendimento da diferença entre conservação e preservação dos recursos naturais.

De acordo com Diegues (1994), por preservação dos recursos naturais entende-se como sendo a manutenção da integridade dos componentes, das interações entre eles e das suas funções (ecológicas, hidrológicas, sociais etc) num determinado ecossistema, alcançada pelo isolamento desse ecossistema das atividades humanas. Já a conservação visa alcançar esses mesmos objetivos, porém aliados ao uso dos bens e serviços do ecossistema pela humanidade; conforme apresentado, a primeira busca manter a integridade e a segunda visa manter a saúde do ecossistema. O plano de manejo é, portanto, a abordagem técnica e científica aplicada para atender as necessidades humanas conservando os recursos naturais, dos quais dependem a satisfação das suas necessidades.

Uma questão crucial para o êxito no uso de indicadores ambientais com vistas ao manejo sustentável é ter como foco a identificação das causas dos impactos ambientais diagnosticados, medidos e avaliados (por meio de indicadores de condição ou do estado 
atual do meio) ou medidos e monitorados (por meio de indicadores de tendência). De outra forma, é imprescindível no uso de indicadores já apontados pela pesquisa, e na identificação de novos indicadores, a busca pela correlação causa-efeito, conforme exemplificado por Dumanski \& Pieri (2000), tratando do tema agro-biodiversidade, quando apresenta um conjunto de indicadores correlacionados às suas causas conforme pode ser visualizado (Tabela 3 ).

Tabela 3. Indicadores propostos para agrobiodiversidade (Dumanski \& Pieri, 2000)

\begin{tabular}{ll}
\hline \multicolumn{1}{c}{ Indicadores de impactos } & \multicolumn{1}{c}{ Causas dos impactos } \\
\hline Perda de habita natural & Ocupação por sistemas de produção agrícola \\
Fragmentação de habitat & Ocupação agrícola de modo desordenado \\
$\begin{array}{l}\text { Perda de espécies quando o habita natural está } \\
\text { Poluição; sedimentação; colheita excessiva etc }\end{array}$ & \\
$\begin{array}{l}\text { intacto } \\
\text { Declínio de biodiversidade de espécies em }\end{array}$ & $\begin{array}{l}\text { Adoção de monoculturas; redução dos cultivos } \\
\text { propriedades agrícolas }\end{array}$ \\
$\begin{array}{l}\text { Declínio de biodiversidade dentro de espécies } \\
\end{array}$ & $\begin{array}{l}\text { Adoção de variedades modernas; expansão de } \\
\end{array}$ \\
\hline
\end{tabular}

Essa mesma lógica apresentada na Tabela 3 deve ser inerente na avaliação e monitoramento dos demais componentes e processos nas diferentes escalas.

Segundo Walker et al.(1996), os processos que determinam a sustentabilidade operam em várias escalas, sendo necessário, portanto, a identificação de diferentes indicadores para as diferentes escalas. É importante observar, que os processos aos quais o autor se refere podem ser tanto hidrológicos quanto ecológicos, pois ambos ocorrem simultaneamente nas diferentes escalas. Esta observação que aqui se faz quanto aos termos hidrológicos e ecológicos, é apenas didática, dado o enfoque do presente trabalho. Essa separação perde o sentido quando se sabe que a ecologia é o estudo do lugar onde se vive e da totalidade das relações entre os organismos e o seu ambiente (Odum, 1988). 
Walker et al. (1996) explicam que poucos indicadores se aplicam a todas as escalas e que quando estes indicadores "multi-escalas" forem identificados serão de grande utilidade. Para monitorar aspectos ambientais, sociais e econômicos, deve-se dispor de um conjunto de indicadores adequados para cada escala espacial.

A noção de que para se avaliar e monitorar a qualidade dos recursos naturais é necessário subdividir o espaço geográfico considerando a organização natural dos componentes e dos processos ecológicos nesse espaço pode ser expressa de modo diferente; entretanto, as suas bases teóricas são as mesmas.

Sob o ponto de vista conceitual e aplicado e com o intuito de fazer uma comparação com o conceito de escalas, serão introduzidos alguns critérios de Eswaran et al. (2000) para hierarquizar a análise do espaço geográfico, subdividindo-o também hierarquicamente, com vistas à avaliação da qualidade dos recursos naturais.

O trabalho desses autores está integrado no Programa de Desenvolvimento de Indicadores de Qualidade dos Recursos Naturais envolvendo BID/FAO/UNEP/UNPD/CGIAR. Segundo os autores, o conhecimento dos recursos naturais e outras informações georeferenciadas com séries históricas, auxiliadas por um sistema de suporte a decisão, são úteis para inferir sobre o potencial desses recursos e, conseqüentemente, definir o que os autores designam por "Domínios de Manejo" para os sistemas de produção de alimentos em todo o mundo.

A meta deste referido Programa tem sido construir um sistema de informação espacial-temporal-hieráquico que descreva os sistemas agrícolas e as comunidades de grupos de nações vizinhas ou de cada país, para conduzir estas informações até o nível regional, para então, finalmente, fazer uma avaliação global.

Para uma grandeza espacial variando de 2,5 a 250 hectares numa escala de análise entre 1:25.000 e 1:250.000, o referido Programa define sub-áreas homogêneas denominadas Resource Management Domain (Domínios do Manejo) (RMD), constituindo-se em áreas geográficas homogêneas quanto ao sistema de uso agrícola, com limites fisiográficos definidos e com características de qualidade de solo semelhantes. Ainda de acordo com os autores, essas áreas também podem ser entendidas como "uma unidade espacial (paisagem) que oferece oportunidades para identificação $e$ 
aplicação de opções de manejo para a solução de questões específicas. A RMD é derivada de informações geo-referenciadas biofísicas e socioeconômicas e ela é dinâmica e multiescala no que se refere às intervenções humanas na paisagem.

Para uma RMD criada, por exemplo, a partir de inventários dos recursos naturais, incluindo mapeamento de solos e com associações com as características climáticas de uma determinada região, onde estes são os únicos dados disponíveis, esta RMD poderá se tornar uma base ou uma estrutura analítica para se avaliar e monitorar o resultado ou o efeito de diferentes opções de manejo.

Diante do exposto, entre outras conclusões pode-se afirmar que a identificação de áreas (paisagens) homogêneas quanto aos seus elementos constituintes, clima, solo, uso pelo homem, manejo, potencialidades e restrições de diversas ordens, conforme proposto pelo Programa LQI - Land Quality Indicators - do Banco Mundial e o conceito de escalas de análise macro, meso e micro, conforme foi discutido (Wlaker \& Reuter, 1996 e Lima, 1999), são orientadas por bases teóricas semelhantes.

Conforme já foi discutido, os processos que determinam a sustentabilidade operam em várias escalas, tornando-se importante que existam diferentes indicadores para diferentes escalas (Walker \& Reuter, 1996).

Assim como as escalas macro, meso e micro, a RMD é uma unidade da paisagem identificada para uma ou mais escalas de análise ambiental.

Concluindo esta comparação, pode-se perceber que a grande diferença entre a noção de escala (Walker \& Reuter, 1996 e Lima, 1999) e a noção de RMD do Banco Mundial é que a primeira tem como premissa básica a consideração da microbacia hidrográfica como sendo em elemento da mesoescala da sustentabilidade, considerando, portanto, o fator hidrológico na organização ecossistêmica da paisagem.

Devido a microbacia hidrográfica ser a manifestação bem definida de um sistema natural aberto e pelo fato de ela integrar os ciclos naturais de energia, nutrientes e principalmente da água, tornando-se a unidade ecossistêmica da paisagem (Odum, 1988; Lima, 1999), pode-se concluir que a consideração do fator hidrológico na subdivisão do espaço geográfico com vistas à avaliação e monitoramento da qualidade dos seus recursos naturais é fundamental. 
Os dois conceitos são, portanto, complementares e podem ser adequadamente utilizados com as devidas adaptações para cada situação concreta.

O processo de desenvolvimento de indicadores é, portanto, orientado por essa concepção espacial da organização dos componentes e processos ecológicos na paisagem.

Portanto, dado o consenso na afirmação de que a microbacia é a unidade consistente de planejamento ambiental, haja vista a sua singularidade na questão da escala de monitoramento (ou aferição) ambiental, e considerando as diferentes categorias de indicadores, o próximo passo é identificá-los nas suas respectivas escalas de atuação para que se possa elaborar um adequado programa de monitoramento.

Antes porém, Lima \& Zakia (1997), a partir de Walker et al. (1996), fazem alguns importantes esclarecimentos sobre monitoramento ambiental de microbacias hidrográficas.

\section{Por que monitorar?}

Os autores embasam a resposta em quatro aspectos:

Primeiro, na atualidade é fundamental saber se as condições do meio vão permanecer adequadas para suprir as necessidades humanas no futuro e por quanto tempo? Isso mostra quão importante é avaliar, por meio do monitoramento, tanto as condições atuais, quanto as tendências desta capacidade natural de suporte do meio ao longo do tempo. Isso remete-nos à subdivisão dos indicadores em indicadores de condição e indicadores de tendência, conforme Walker et al. (1996).

Segundo, o monitoramento também se justifica economicamente pelo fato de que pode orientar os investimentos com vistas à melhoria da produtividade e a fim de evitar a degradação do solo e da água.

O terceiro aspecto da resposta é o de que o monitoramento deve sempre ter como meta a melhoria contínua das práticas de manejo, visando a busca da sustentabilidade.

No quarto aspecto, considerando a discussão atual sobre desenvolvimento sustentável, o monitoramento deve ser voltado para a identificação e o teste de indicadores ambientais, ou seja, de parâmetros que similarmente aos já conhecidos indicadores econômicos, possam sinalizar, de forma rápida e competitiva, as condições e 
as tendências do ambiente causada pelas atividades de manejo.

Diante disso, os autores concluem que, a partir desses conceitos básicos, o monitoramento ambiental em microbacias tem como meta a identificação e a verificação de indicadores da saúde da microbacia, tanto em termos de indicadores de condição como de tendência.

O monitoramento, portanto, além de subsidiar estudos sobre funcionamento hidrológico de microbacias, fundamentais para o estabelecimento de modelos de predição, orienta o manejo ao nível de propriedade agrícola ou de talhões a partir da interpretação das respostas fornecidas pelos indicadores hidrológicos de sustentabilidade.

Dentro da etapa monitoramento, a avaliação e interpretação dos resultados obtidos pelo emprego (medições, avaliação) de indicadores são de fundamental importância e deve ser efetuada com base em critérios pré-estabelecidos.

Segundo Eswaran et al. (2000) a determinação da dinâmica de mudanças na qualidade dos recursos naturais é fundamental para a orientação de planejamentos que vão desde a formulação de políticas nas diferentes esferas, nacional, estadual, regional, passando pela microbacia, até a tomada de decisão pelos administradores rurais, agricultores, aqueles que efetivamente poderão ou não alterar o seu manejo dependendo de diversos fatores. Para os autores, essas mudanças nas condições dos recursos naturais são o resultado cumulativo das mudanças em cada elemento e em cada processo do ecossistema, ao longo de um dado período de interesse. A avaliação dessas alterações requer o conhecimento das condições do "marco zero", de um adequado período de monitoramento, de padrões de comparação e de uma adequada metodologia e frequiência de medição.

Os padrões de comparação podem ser:

- Os próprios valores obtidos pelas medições da condição do ambiente no marco zero;

- Níveis históricos;

- Níveis estabelecidos pela legislação;

- Níveis de qualidade desejados pela sociedade, comunidades rurais, agricultores etc;

- Níveis potenciais, por exemplo, de produtividade. 


\subsubsection{Ecossistema ripário}

Como será visto ao longo deste tópico, o ecossistema ripário se constitui em um importante indicador da saúde de uma microbacia. Embora ele seja um dos indicadores da escala meso, os quais estão descritos adiante, dado a riqueza e a complexidade das informações sobre esse componente, ele será tratado separadamente.

De acordo com Lima (1989) a zona ripária representa tanto a porção do terreno que inclui a ribanceira do rio propriamente dita, como também a planície de inundação, com suas condições edáficas próprias e a vegetação que aí ocorre (a mata ripária ou ciliar). Ao conjunto zona ripária, mata ripária, bem como a interação entre elas atribui-se o nome de ecossistema ripário.

Gregory et al. (1991) definem funcionalmente a zona ripária como uma zona tridimensional de interação entre os ecossistemas terrestres e aquáticos.

O ecossistema ripário desempenha sua função hidrológica por meio de (Lima, 1989):

- Estabilização das ribanceiras dos rios (áreas críticas do ponto de vista hidrológico), pelo desenvolvimento e manutenção de um emaranhado radicular;

- Como tampão e filtro entre os terrenos mais altos e o ecossistema aquático, participa do controle do ciclo de nutrientes na bacia hidrográfica, através de ação tanto no escoamento superficial, quanto na absorção de nutrientes do escoamento subsuperficial pela vegetação ciliar;

- Pela diminuição e filtragem do escoamento superficial, impede ou minimiza o carreamento de sedimentos para o sistema aquático, contribuindo, desta forma, para a manutenção da qualidade da água nas bacias hidrográficas;

- Pela sua integração com a superfície da água, proporciona cobertura e alimentação para peixes e outros componentes da fauna aquática;

- Essa integração com a superfície da água propicia ainda a estabilidade térmica dos pequenos cursos d'água, como conseqüência da interceptação da radiação solar. 
Diversos trabalhos já comprovaram a eficiência da mata ciliar na manutenção da qualidade da água de uma microbacia. Os trabalhos de Gregory et al. (1991) e Lowrance et al. (1984) demonstraram que o ecossistema ripário desempenha uma função fundamental na regulação das interações entre os ecossistemas terrestre e aquático de paisagens situadas na zona temperada.

Zakia (1998) afirma que o resultado direto da função da mata ciliar na hidrologia da microbacia hidrográfica pode ser verificado, com mais facilidade, em termos da qualidade da água do deflúvio.

As matas ciliares têm importante papel na conservação das características e da qualidade do ecossistema aquático de uma microbacia.

Segundo Lima \& Zakia (2000), as zonas ripárias são fundamentais para a manutenção da saúde da microbacia e, conseqüentemente, dos recursos hídricos, os quais dizem respeito à geração do escoamento direto nas microbacias em decorrência das chuvas. Para que essas áreas possam exercer essa função, é fundamental que elas estejam adequadamente protegidas com a vegetação ripária, mata ciliar ou outra forma de vegetação que naturalmente se desenvolve nessas áreas.

Zakia (1998) aferiu e parametrizou o modelo MESS (modelo de escoamento subsuperficial) o qual foi obtido a partir do TOPMODEL, disponibilizando, assim, uma metodologia para a simulação de vazão em microbacias, bem como para a determinação da zona ripária. Esse mapeamento da zona ripária em microbacias hidrográficas pode ser feito por meio da análise digital da topografia do terreno.

Assim sendo, tanto a presença da mata ciliar, a composição e a estrutura dessa vegetação, quanto a quantidade e qualidade da água que circula no ecossistema podem ser considerados importantes indicadores da saúde dos ecossistemas ripários. A saúde deste último, por sua vez é um importante indicador da saúde da microbacia hidrográfica.

Diante dessas funções apresentadas e com base no conceito de saúde da microbacia hidrográfica, torna-se evidente a importância da conservação de todos os componentes do ecossistema ripário, dentre os quais, se destaca a mata ciliar. 
Portanto, no manejo de microbacias hidrográficas, principalmente naquelas ocupadas por áreas de exploração agropecuária, além de planejar adequadamente o uso da terra de modo a melhorar as condições de infiltração de água no solo e conseqüentemente minimizar a erosão, é de fundamental importância a proteção dos cursos d’água com as matas ciliares. É imperativo, portanto, o adequado planejamento do uso das diferentes escalas da sustentabilidade, ou seja, escalas micro, meso emacro, conforme a presente discussão.

\subsubsection{Qualidade e quantidade de água e regime de vazão em microbacias}

Uma premissa básica do uso de microbacias experimentais em estudos de monitoramento ambiental com vistas, por exemplo, à identificação e validação de indicadores é que as atividades de uso dos recursos naturais vão, necessariamente, causar algum efeito sobre os recursos hídricos. Operacionalmente, essa premissa quer dizer que já está provado cientificamente que é possível avaliar o uso, ou o mau uso, da terra por meio do monitoramento de alguma propriedade da água superficial ou subsuperficial que emana de uma microbacia (Lima \& Zakia, 1997).

A qualidade da água é avaliada com base nos seus atributos físicos, químicos e biológicos. Conforme dito acima, os resultados de pesquisas de monitoramento ambiental de microbacias hidrográficas experimentais vem comprovando a eficiência e a eficácia de se avaliar a saúde de microbacias a partir da medição e do monitoramento de indicadores de qualidade de água; evidenciam, portanto, a correlação de causa-efeito necessária entre os diferentes atributos e os impactos sobre a qualidade da água, a quantidade de água (deflúvio), e o regime de vazão, sendo esses, portanto, importantes indicadores para a verificação da eficácia ecológica do manejo adotado na escala da microbacia (mesoescala da sustentabilidade). Nesse contexto, um aspecto fundamental para o correto planejamento de um programa de monitoramento diz respeito à busca pela identificação dos impactos sobre a qualidade da água decorrentes das atividades realizadas na microbacia. Essa compreensão é crucial para a seleção das variáveis indicadoras a serem monitoradas, assim como de sua periodicidade e sazonalidade 
(Lima \& Zakia, 1996; 1997).

De acordo com Jolly et al. (1996) a qualidade da água superficial e subsuperficial são bons indicadores, respectivamente, de tendência e de condição (estado atual) de uma microbacia. Esses autores abordam um fator fundamental na avaliação da qualidade da água que é a grande variação da vazão temporalmente e espacialmente. As concentrações de sais, sedimentos, nutrientes e outros produtos químicos e biológicos, são dependentes das condições de vazão, sendo isto de crucial importância tendo em vista que essas variáveis são largamente utilizadas para a avaliação da qualidade da água.

Do ponto de vista operacional, uma conseqüência direta dessa informação é que para se comparar diferentes cursos d'água em uma microbacia ou para se investigar mudanças que ocorrem num mesmo local ao longo do tempo, a influência das diferentes condições de vazão devem ser removidas. Dado que a carga de contaminantes da água é calculada pela multiplicação das respectivas concentrações pela vazão, monitorando-se esta última (vazão) no tempo e no espaço pode-se chegar a uma correta comparação espacial e/ou temporal da carga poluente, ou seja, fazer a comparação para uma mesma condição de vazão.

Entretanto esses autores afirmam que pelo monitoramento de um conjunto adequado de indicadores (diretos ou indiretos) dentro de uma estrutura de amostragem espacial e temporal apropriada para uma determinada microbacia, poderá revelar tendências na qualidade da água e auxiliar na identificação das suas causas.

A Figura 3 apresenta uma relação das impurezas mais comumente encontradas nas águas naturais. Como já discutido, um aspecto fundamental do conceito de indicadores é que eles representam os atributos chaves para a avaliação e monitoramento dos componentes e processos ecológicos. Portanto, dentre as características químicas da água apresentadas na Figura 3, devem ser medidas e monitoradas apenas aquelas que se prestam como indicadoras para o objetivo que se tem. 


\begin{tabular}{|c|c|c|c|c|}
\hline Origem & $\begin{array}{c}\text { Impurezas } \\
\text { Dissolvidas }\end{array}$ & Coloidais & $\begin{array}{c}\text { Em } \\
\text { suspensão }\end{array}$ & Gases \\
\hline $\begin{array}{l}\text { Contato da água } \\
\text { com minerais, } \\
\text { solos, rochas }\end{array}$ & $\begin{array}{lr}\text { Cálcio } & \text { Bicarbonatos } \\
\text { Ferro } & \text { Carbonatos } \\
\text { Magnésio } & \text { Cloretos } \\
\text { Manganês } & \text { Nitratos } \\
\text { Potássio } & \text { Fosfatos } \\
\text { Sódio } & \text { Silicatos } \\
\text { Zinco } & \text { Sulfatos }\end{array}$ & $\begin{array}{l}\text { Argila } \\
\text { Sílica } \\
\text { Óxido de ferro } \\
\text { Óxido de Alumínio } \\
\text { Dióxido de magnésio }\end{array}$ & $\begin{array}{l}\text { Argila } \\
\text { Silte } \\
\text { Areia }\end{array}$ & Gás carbônico \\
\hline $\begin{array}{l}\text { Atmosfera, } \\
\text { chuva }\end{array}$ & $\begin{array}{l}\text { Hidrogênio }\left(\mathrm{H}^{+}\right) \\
\text {Bicarbonatos } \\
\text { Cloretos } \\
\text { Sulfatos }\end{array}$ & & $\begin{array}{l}\text { Poeira } \\
\text { Pólen }\end{array}$ & $\begin{array}{l}\text { Gás carbônico } \\
\text { Nitrogênio } \\
\text { Oxigênio } \\
\text { Dióxido de } \\
\text { Enxofre }\end{array}$ \\
\hline $\begin{array}{l}\text { Decomposição } \\
\text { de matéria } \\
\text { orgânica no meio } \\
\text { ambiente }\end{array}$ & $\begin{array}{lc}\text { Amônia } & \text { Cloretos } \\
\text { Hidrogênio }\left(\mathrm{H}^{+}\right) & \\
\text {Nitritos } & \text { Sódio } \\
\text { Nitratos Sulfitos } & \text { Radicais orgânicos }\end{array}$ & $\begin{array}{l}\text { Cor de origem vegetal } \\
\text { Resíduos }\end{array}$ & $\begin{array}{l}\text { Solo } \\
\text { orgânico } \\
\text { Resíduos } \\
\text { orgânicos }\end{array}$ & $\begin{array}{l}\text { Amônia } \\
\text { Gás carbônico } \\
\text { Gás sulfídrico } \\
\text { Hidrogênio } \\
\text { Metano } \\
\text { Nitrogênio } \\
\text { Oxigênio }\end{array}$ \\
\hline $\begin{array}{l}\text { Organismos } \\
\text { vivos }\end{array}$ & & $\begin{array}{l}\text { Bactérias } \\
\text { Algas } \\
\text { Vírus }\end{array}$ & $\begin{array}{l}\text { Algas } \\
\text { Zooplâncton } \\
\text { Peixes }\end{array}$ & $\begin{array}{l}\text { Amônia } \\
\text { Gás carbônico } \\
\text { Metano }\end{array}$ \\
\hline $\begin{array}{l}\text { Fontes } \\
\text { antropogênicas }\end{array}$ & $\begin{array}{l}\text { Ions inorgânicos } \\
\text { Metais pesados } \\
\text { Moléculas orgânicas } \\
\text { Cor }\end{array}$ & $\begin{array}{l}\text { ORganoclorados } \\
\text { Corantes } \\
\text { Bactérias } \\
\text { Vírus }\end{array}$ & $\begin{array}{l}\text { Sólidos } \\
\text { inorgânicos } \\
\text { Compostos } \\
\text { orgânicos } \\
\text { Óleos } \\
\text { graxas }\end{array}$ & $\begin{array}{l}\text { Cloro } \\
\text { Dióxido } \\
\text { enxofre }\end{array}$ \\
\hline
\end{tabular}

Figura 3 - Impurezas mais freqüentes encontradas nas águas naturais (Porto, 1998)

Os sedimentos transportados pelo escoamento superficial (erosão) têm como destino direto os cursos d'água, interferindo na qualidade da água produzida na microbacia, ou seja, no deflúvio. Portanto, a busca de indicadores da qualidade da água vem sendo motivo de vários estudos nessa área da pesquisa.

Segundo Arcova (1996) a condutividade elétrica pode ser muito útil para detectar variações nas características qualitativas da água, pois está diretamente relacionada com a concentração total de íons. Câmara (1999), avaliando a qualidade da água numa microbacia experimental, concluiu que os parâmetros físicos da água como a turbidez, a cor, a condutividade elétrica e os sedimentos em sus pensão apresentaram-se como bons indicadores qualitativos do deflúvio. A turbidez e a cor estão associadas à presença de material em suspensão na água como argilas, detritos orgânicos que impedem a 
passagem de luz, sendo largamente utilizados para inferir-se sobre a perda de solos.

Entretanto, pelo fato de se tratar de uma propriedade óptica da amostra, não é recomendada a tentativa de correlacionar os valores de turbidez com a concentração de sedimentos, uma vez que a forma, o tamanho, o índice de refração e outras propriedades das partículas são importantes do ponto de vista óptico, mas guardam pouca relação direta com a concentração e a massa específica da matéria em suspensão na amostra (Lima, 1996). A água tratada e destinada ao consumo deve ter turbidez inferior a 5 UNT, porque o material em suspensão pode servir de proteção a microorganismos patogênicos presentes na água, impedindo seu contato com as substâncias desinfetantes (Porto et al., 1991).

A condutividade elétrica, por sua vez, presta-se nesse caso para inferir-se sobre a perda de nutrientes.

A turbidez tem se mostrado com alta sensibilidade ao manejo físico do solo, sendo portanto um bom indicador da qualidade da água com relação ao arraste de sedimentos.

\subsubsection{Qualidade do solo}

Tendo como objetivo avaliar a qualidade do solo, faz-se necessário buscar algumas definições sobre esse conceito e identificar aquela que será referência para o presente estudo.

Para Karlen et al. (1994), qualidade do solo é definida como sendo a capacidade desse solo em desempenhar a sua função em um ecossistema para suportar plantas e animais, resistir à erosão e reduzir impactos negativos associados aos recursos água e ar.

De acordo com Islam \& Weil (2000), a qualidade do solo, sendo um estado funcional complexo, não pode ser medida diretamente, mas pode ser inferida a partir de propriedades do solo designadas como propriedades indicadoras da qualidade do solo.

De acordo com Dumanski \& Pieri (2000) as bases científicas que respaldam a busca por indicadores de qualidade do solo são a compreensão de que esses indicadores estão direcionados para a avaliação e ou monitoramento das condições do solo que o 
tornam um corpo vivo. De outra forma, esses indicadores específicos desta escala devem ter a capacidade e a sensibilidade para medir e avaliar atributos e processos do solo que interfiram na promoção da sua vida.

Dumanski \& Pieri (2000) afirmam que é preciso encontrar um indicador definitivo que integre os dados dos atributos físicos, químicos e taxonômicos com a biologia do solo, incluindo neste caso a possibilidade de monitorar a cadeia alimentar do solo.

Enquanto não se disponha de resultados que possibilitem apontar esse indicador maior (um índice de qualidade do solo) o Programa de LQI do $\mathrm{BID} / \mathrm{FAO} / \mathrm{UNEP} / \mathrm{UNPD} / \mathrm{CGIAR}$, propõe o desenvolvimento de um substitutivo (surrogate) de qualidade do solo, a partir dos dados de matéria orgânica do solo, mais especificamente, o estoque de carbono microbiano do solo (carbono de células bacterianas e fúngicas).

Duamanski \& Pieri (2000) sugerem que a qualidade do solo e a agrobiodiversidade estão intimamente ligadas e, desse modo, devem ser avaliadas em conjunto por meio da caracterização dos principais grupos funcionais no solo, especificamente a macrofauna (minhocas e cupins), nematóides, microorganismos simbiontes (micorrizas e fixadores de nitrogênio) e biomassa microbiana (fungos, bactérias e protistas).

A orientação dessa pesquisa ainda coloca duas questões chaves que devem ser respondidas pelo uso desses indicativos da qualidade do solo:

- As práticas atuais de manejo do solo mantêm, aumentam ou reduzem a capacidade/habilidade da matéria orgânica do solo para desempenhar as suas funções, que por sua vez promovem a condição de um solo vivo?

- As práticas atuais de manejo do solo mantêm a vida biológica e a biodiversidade do solo, e deste modo melhoram a resiliência ambiental do solo para a manutenção de funções que suportam a vida global?

Karlen et al. (1994) explica que as práticas de manejo que adicionam ou mantém carbono orgânico no solo parecem estar entre as mais importantes para restabelecer, manter ou melhorar a qualidade do solo.

Essa explicação é bastante norteadora para a busca de indicadores de qualidade do solo, pois mostra que os atributos candidatos a indicadores que têm intima relação com a 
matéria orgânica tem maior chance de serem adequados para o objetivo em questão.

Os critérios de escolha de indicador de qualidade ou de saúde do solo são dependentes dos objetivos que se tem e do contexto.

Entretanto, um critério que deve sempre existir, independentemente da situação, diz respeito à sensibilidade do indicador às alterações no processo e ou no componente da microbacia ao(s) qual (is) ele se aplica.

Nesse respeito, Powlson et al. (1987) afirmam que a biota do solo é mais sensível às mudanças nas condições do solo do que o carbono orgânico total do solo, embora este último tenha sido apontado como um importante indicador da saúde do solo.

Segundo Altieri (2002), apesar da matéria orgânica encontrar-se numa faixa de apenas 1 a $6 \%$ em percentagem de peso na maioria dos solos, quando é bem manejada, a quantidade e qualidade da matéria orgânica levam a um aumento na disponibilidade de nutrientes e na diversidade biológica, além de melhorar as propriedades físicas e químicas do solo.

Para exemplificar esta afirmação, será apresentado brevemente o trabalho de Islam \& Weill (2000), os quais para avaliar o efeito de diferentes usos do solo sobre a sua qualidade, monitoraram ao longo de vários anos as seguintes propriedades:

- Carbono Total da biomassa microbiana

- Biomassa microbiana ativa

- Respiração basal

- Carbono orgânico total

- Nitrogênio total

- Taxa de amonificação

- Nitrogênio potencialmente mineralizável

- Estabilidade de macro-agregados

- $\mathrm{pH}$ do solo

- Macroporosidade

- Densidade do solo

- Textura 
A Densidade de partículas foi assumida como igual a $2,65 \mathrm{~g} . \mathrm{cm}^{-3}$

Islam \& Weil (2000) compararam o efeito de diferentes sistemas de manejo sobre a qualidade do solo, tendo o manejo conservacionista como o padrão de comparação, pois é sabido que esse manejo, adotando práticas que sustentam a matéria orgânica do solo (conforme será descrito a seguir), melhora a qualidade do solo. A partir da avaliação do efeito dos manejos sobre as treze propriedades indicadoras descritas acima, os autores buscaram agregar aquelas mais consistentemente afetadas, em um Índice de Qualidade de Solo. Sendo o índice um valor simples que integra muitas medidas de propriedades chaves do solo.

Quanto ao desenho experimental desse referido estudo, foram consideradas áreas com histórico de manejo convencional e conservacionista. As áreas de manejo conservacionista comparadas com as de manejo convencional se diferenciaram pela combinação (no desenho experimental) de cultivo reduzido, pela maior diversidade de cultivos por rotação de culturas e pela presença de cultivos perenes, maior retorno de resíduos orgânicos para o solo pelo uso de plantas de cobertura, pela maior adição de fertilizantes orgânicos e, conseqüentemente, se diferenciaram pela maior fertilidade do solo. As amostras de solo foram coletadas ou no início da primavera (antes do plantio) ou então com um período mínimo de nove meses sem distúrbio, quando possível.

Os resultados do trabalho de Islam \& Weil (2000) mostraram que o carbono orgânico total, apesar de ter apresentado aumento em função do manejo conservacionista, não foi consistentemente sensível a esse manejo. O quociente metabólico apresentou comportamento inversamente proporcional à qualidade do solo, ou seja, aumentos no quociente metabólico indicam perda de qualidade do solo.

As três propriedades que se mostraram mais promissoras para inclusão em um índice de qualidade do solo foram Biomassa Microbiana Total, Biomassa Microbiana Ativa, Quociente Metabólico (ou Taxa de Respiração Específica), sendo essas as mais significativamente influenciadas pelo manejo conservacionista, em mais de $75 \%$ das comparações. Uma quarta propriedade também fortemente influenciada pelo manejo conservacionista foi a Estabilidade de Agregados e os demais atributos físicos avaliados que têm forte relação com a matéria orgânica, Macroporosidade e Densidade do Solo. 
Os autores então concluíram que a biomassa microbiana total e ativa, o quociente metabólico e a estabilidade de agregados possibilitam a sua utilização em estudos posteriores para servirem como indicadores gerais da qualidade de solos agrícolas com vistas à elaboração de um índice de qualidade do solo.

Os benefícios advindos da inclusão de gramíneas no esquema de rotação de culturas, da minimização do cultivo e do uso de plantas de cobertura de inverno também ficaram bem evidentes nos resultados destes autores.

Esta sensibilidade da matéria orgânica às alterações no manejo do solo está, no entanto, relacionada com a camada do solo onde ela é monitorada. Isso porque a matéria orgânica particulada existente na superfície do solo (na interface solo-liteira) é a mais lábil de toda a matéria orgânica do solo e, portanto, é a fonte de carbono orgânico mais sensível às mudanças nas condições do solo. Deste modo, considerando essas particularidades, a matéria orgânica é um importante indicador de fertilidade e de saúde do solo (Papendik et al.1992).

Segundo Parton et al. (1989), modelos de dinâmica da matéria orgânica do solo consideram três frações principais, com diferentes tempos de ciclagem: a fração ativa ( 0 14 anos), a fração lenta (5 anos) e a fração passiva (150 anos). Os autores explicam que em função dessas diferenças, a resposta da matéria orgânica do solo às alterações do uso da terra e as práticas de manejo podem ser imperceptíveis por décadas, enquanto a resposta da fração ativa que contém a biomassa microbiana e seus metabólicos, ocorre muito mais rapidamente.

O entendimento do solo como um corpo vivo significa considerar que todos os seus processos e componentes estão funcionalmente bem integrados. Portanto, a vida do solo e os seus processos vitais são expressos e regulados pela biota do solo. Essa regulação da biota sobre a decomposição de resíduos orgânicos, ciclagem de nutrientes, degradação de poluentes químicos e a sua forte influência sobre a estrutura do solo, fazem com que esses microorganismos e esses processos sejam naturalmente escolhidos como indicadores da saúde ou da qualidade do solo (Papendik et al.1992).

Para situar os aspectos teóricos que estão sendo discutidos e evitar equívocos quanto às terminologias, faz-se necessário uma definição da abrangência do termo biota 
do solo.

De acordo com Papendik et al. (1992) a biota do solo é categorizada de acordo com o tamanho dos organismos, sendo microorganismos as bactérias, fungos, actinomicetos e algas; microfauna (protozoários); mesofauna (colembola, nematóides); macrofauna (minhocas, diplópodes ou miriápodes, insetos grandes). E dando uma visão geral do estudo da biota de solos esses mesmos autores explicam que ela pode ser estudada ao nível de organismos (pela presença / ausência de determinadas espécies ou pela biomassa dessas espécies) ou ao nível de comunidade (biomassa e atividade respiratória do solo, grupo de espécies, grupos funcionais). Dada a importância do processo de ciclagem de nutrientes no aspecto funcional do solo, é importante ressaltar que a maior parte da biota do solo está relacionada com esse processo. Especificando a importância relativa de cada categoria de organismos da biota para o solo, Waker \& Reuter (1996) afirmam que a função do ecossistema solo é governada principalmente pela dinâmica dos microorganismos.

Um importante aspecto a ser considerado no estudo dos microorganismos do solo é que estes vivem na película de água localizada entre as suas partículas e dessa forma, a densidade da população microbiana depende da umidade do solo (Tibau, 1977).

Papendik et al. (1992) explicam que índices microbiológicos baseados em mais de um parâmetro podem ser capazes de discriminar o efeito de diferentes sistemas de manejo sobre a qualidade do solo e, dessa forma, os autores apontam o quociente microbiano e o quociente metabólico como sendo bons indicadores para tais comparações.

De acordo com Waker \& Reuter (1996) o quociente metabólico $\left(\mathrm{qCO}_{2}\right)$ é taxa de respiração basal por unidade de biomassa microbiana $\left(\mathrm{CO}_{2}\right.$ liberado / $\mathrm{C}$ biomassa) e é calculada pela relação entre a quantidade de $\mathrm{CO}_{2}$ desprendido da amostra de solo incubada e a quantidade de carbono na biomassa microbiana.

Esse quociente tem sido apontado como um indicador do estresse microbiano, pois ele expressa a energia necessária para a manutenção da atividade metabólica em relação à energia necessária para a síntese da própria biomassa (Bardgett \& Saggar,1994). Corroborando essa afirmação, Islam \& Weill (2000) obtiveram resultados consistentes 
para afirmar que com a melhoria da qualidade do solo o quociente metabólico diminui, ou seja, o quociente metabólico é negativamente correlacionado com a qualidade do solo sendo, portanto um indicador do seu estresse, distúrbio ou desequilíbrio funcional.

O quociente microbiano é a relação entre o carbono orgânico da biomassa microbiana e o carbono orgânico total do solo (Cmic / Corg. Total) e expressa a quantidade de carbono imobilizado na biomassa microbiana (Silva, 2001).

A obtenção desses dois quocientes depende da determinação do desprendimento de $\mathrm{CO}_{2}$ do solo (respiração), do carbono da biomassa microbiana e do carbono total do solo (Papendik et al.1992).

Segundo Poggiani et al. (1977) o dióxido de carbono resultante da respiração edáfica, medida em campo, origina-se tanto da respiração da biota do solo como da respiração do sistema radicular e do total de $\mathrm{CO}_{2}$ liberado pela respiração edáfica, 30$50 \%$ pode ser oriundo da respiração radicular.

Groffman et al. (2001) realizaram um estudo em áreas de ecossistema ripário, comparando o efeito da mudança no uso da terra sobre a biomassa e a atividade microbiana do solo; a amostragem do solo foi feita na camada de $0-15 \mathrm{~cm}$ do perfil e restringiu-se a uma faixa de $15 \mathrm{~m}$, demarcada a partir do leito central do curso d'água, onde a profundidade do lençol variava de 0,3 a 1,0 m. Foram comparados solos sob floresta intacta, floresta perturbada, pastagem de 10 anos (variando entre 10 e $25 \%$ de cobertura arbórea) e usos marginais (caracterizados pela presença de florestas temporárias, trilhas, pastagens, suinocultura). A amostragem desses quatro tipos de uso foram efetuadas em duas repetições, nas proximidades das vilas de Puerto Viejo (profundidade média do lençol igual a $0,75 \mathrm{~m})$ e de Gandoca $(0,37 \mathrm{~m})$ no sudoeste da Província de Talamanca, Costa Rica. A frequiência de amostragem considerou dois períodos de quatro dias, sendo um na estação úmida (junho) e outro na estação seca (fevereiro). Esse trabalho concluiu que os conteúdos de carbono e nitrogênio do solo foram pouco controlados pela sua textura e que tanto a biomassa microbiana quanto a atividade dos microorganismos do solo sob floresta intacta não foi superior aos demais usos da terra, como seria esperado. Ao contrário, os valores dessas duas variáveis foram em alguns casos, significativamente, menores no solo sob floresta intacta do que nos 
demais tipos de uso da terra. Diversas hipóteses foram formuladas pelos autores para explicar os resultados, discutindo desde o próprio delineamento experimental, a inexistência dos dados de densidade do solo, até o fato de que as áreas de florestas intactas, não terem sido utilizadas até então devido a sua pequena fertilidade natural. Nesse sentido, com base na alta correlação encontrada entre conteúdo de matéria orgânica e essas duas variáveis em questão, uma importante hipótese do estudo foi de que os sistemas com alto potencial de produção de matéria orgânica têm conseqüentemente alta biomassa e alta atividade microbiana. Portanto, o efeito da conversão de áreas nativas para outros usos sobre essas variáveis depende do potencial do sistema sucessor em produzir matéria orgânica. Outra questão interessante colocada pelos autores é que o fator sucessional da vegetação pode ajudar a explicar os resultados, pois os locais perturbados pela ação humana possuem vegetação mais jovem, em pleno crescimento vegetativo e, portanto, com maior potencial de produção de matéria orgânica.

É fundamental considerar aqui, que essa conclusão em hipótese alguma respalda a de que o desmatamento não causará nenhum efeito negativo sobre a qualidade dos recursos naturais, porque os inúmeros bens e serviços das florestas úteis à sobrevivência do homem e para a manutenção da capacidade de suporte dos ecossistemas globais, devem ser substancialmente considerados. Ainda, as questões de ordem política, econômica e social, principalmente com relação a distribuição mais equiitativa de renda e poder, devem ser ponderadas quando se busca justificar o desmatamento para atender as demandas por alimentos, fibras e energia pela população, tendo em vista que tais questões são algumas das causas principais da fome no país e no mundo.

Outro indicador microbiológico sugerido por Papendik et al.(1992) é a diversidade microbiana do solo. Determinadas práticas ou distúrbios que atuem sobre o solo levam a alterações quantitativas e qualitativas na diversidade microbiana, selecionando espécies adaptadas e ou tolerantes a essas condições de modo que a análise dessas alterações permite a avaliação da qualidade do solo (Kennedy \& Smith, 1995). 


\section{Atributos físicos}

Diante do exposto até o presente momento e considerando a categorização dos indicadores em indicadores de condição e de tendência, claro é que os indicadores de qualidade de solo devem ser sensíveis às mudanças funcionais que nesse corpo vivo se operam e, para isso, os indicadores analisados em conjunto devem responder pelas alterações nos diferentes componentes e processos que possibilitam a funcionalidade do solo.

Desse modo, buscando vincular coerentemente a biologia e a física do solo, a partir de propriedades e componentes chaves dessas duas áreas, Tibau (1977) explica o seguinte:

A estrutura ativa do solo, ao invés de ser um estado puramente físico e apático, como se fosse apenas uma formação arquitetônica pura e simples, representa, ao contrário, o resultado de um complexo processamento biológico contínuo, permanentemente ativado pela energia gerada através da matéria orgânica e suprida aos microorganismos e a mesofauna, que são os agentes atuantes responsáveis e sede de um grande número de fenômenos bioquímicos, de vital importância para o atendimento às múltiplas funções nessa dinâmica biocenose. Se assim é, e por múltiplas outras razões, a microbiologia e a zoologia do solo têm importância fundamental no seu estudo.

Ainda segundo Tibau (1977), a descoberta de que os micélios de fungos envolvem as partículas do solo e que as exsudações bacterianas de substâncias gomosas de efeito aglutinante contribuem para a estruturação do solo data de 1938.

Concordando com o exposto, Walker \& Reuter (1996) explicam que a qualidade física do solo também pode ser entendida como sua qualidade estrutural.

Para a saúde da microbacia hidrográfica, a qualidade física do solo é importante por duas razões principais:

Primeiro, pela íntima relação entre as propriedades físicas do solo e os processos hidrológicos que operam na microbacia, isto é, infiltração, escoamento superficial, escoamento subsuperficial, drenagem profunda e erosão. 
A segunda razão está relacionada com a função dominante da qualidade física do solo na regulação do suprimento e armazenamento de muitos dos requerimentos fundamentais para o crescimento e desenvolvimento das plantas (água, nutrientes e oxigênio).

Para Walker et al., (1996) a estabilidade estrutural do solo é melhorada por altos níveis de atividade biológica, estando intimamente associada com o conteúdo de matéria orgânica.

Essas considerações sobre a importância da estrutura do solo também foram explicadas por Primavesi (1952), complementando a explicação anterior pela relevância que esta autora dá à biologia do solo. De acordo com a autora, a estrutura do solo desenvolvida pela atividade microbiana confere ao solo forma e grau ideais de permeabilidade e assim sendo, esse condicionamento perfeito e vital resolve simultaneamente o problema da erosão, cuja intensidade é inversamente proporcional à permeabilidade do solo e, diminui consideravelmente os problemas oriundos das secas e das enchentes e também das baixas produtividades. A autora ainda explica que esses benefícios simultâneos são possíveis devido à ótima relação que se obtém entre alta permeabilidade e elevada capacidade de retenção de água do solo.

O trabalho de Primavesi (1952) foi realizado em terras de cultivo de trigo no Estado de São Paulo, compactadas, praticamente estéreis onde o escoamento superficial era de $84 \%$ e a permeabilidade não ultrapassava $7 \mathrm{~cm}$ de profundidade (observações de campo após uma chuva). A pesquisadora restabeleceu a permeabilidade do solo pela adição de matéria orgânica, micronutrientes e fósforo, práticas essas que dinamizaram a ação dos microorganismos. A comparação dos dados iniciais da área com aqueles obtidos após cinco anos de tratamento do solo, sem a adoção de práticas mecânicas de conservação dos solos, estão apresentados na Tabela 4. 
Tabela 4. Efeito da ação dos microorganismos do solo sobre algumas propriedades físicas do solo

\begin{tabular}{l|c|c|c}
\hline $\begin{array}{c}\text { Período de } \\
\text { avaliação }\end{array}$ & $\begin{array}{c}\text { Escoamento } \\
\text { superficial } \\
(\boldsymbol{\%})\end{array}$ & $\begin{array}{c}\text { Capacidade } \\
\text { deretenção de água }\end{array}$ & $\begin{array}{c}\text { Volume de poros } \\
(\boldsymbol{\%})\end{array}$ \\
\hline Inicial & 84 & $(\boldsymbol{\%})$ & 9,3 \\
5 anos depois & 7 & 4,2 & 46 \\
\hline
\end{tabular}

Ao condicionamento do solo, por meio da matéria orgânica e da atividade biológica, Primavesi (1952) deu o nome de estrutura ativada.

Essas explicações acima, trazem importantes esclarecimentos para a avaliação da saúde do solo, pois comprovam que a estrutura ativada é um indicador fundamental da sua qualidade ou de sua saúde.

Com relação a esse assunto de hidrologia de microbacias, Valente (1999) faz importantes considerações. Para a produção de água com regularidade na microbacia, dois processos do ciclo hidrológico são fundamentais: a infiltração e a evapotranspiração. $\mathrm{O}$ autor explica que a infiltração possibilita o armazenamento temporário de uma parte da água no solo e o segundo devolve parte dela à atmosfera, onde o balanço entre ambos quantificará a água que irá formar a vazão do curso ao longo do ano, ou seja, determinará o regime de vazão.

Portanto, quanto melhor a estrutura ativa do solo, melhores serão as condições de infiltração e tendendo a haver um regime de vazão mais constante ao longo do ano.

Portanto, na avaliação da saúde da microbacia, grandes oscilações dos valores do indicador hidrológico de sustentabilidade regime de vazão em função do regime de chuvas, são interpretadas como um forte indicativo de que a estruturação do solo não está adequada, favorecendo o escoamento superficial em detrimento da infiltração e escoamento subsuperficial. Isso reforça as afirmações anteriores de que os indicadores devem ser analisados em conjunto, mas para isso é preciso metodologicamente estruturar e organizar hierarquicamente (no espaço) as suas medições, tendo como base a noção de escala apresentada anteriormente. 
Segundo Vieira (1975), entende-se por estrutura do solo a agregação de suas partículas individuais em partículas compostas que recebem o nome de agregados e, estes por sua vez, associam-se dando origem aos torrões. Estes são a parte macroscópica da estrutura do solo. A unidade individual da estrutura do solo recebe o nome de PED. De modo complementar, a estrutura pode também ser entendida como um termo que descreve a agregação ou distribuição total (dispersão) das principais estruturas granulométricas do solo (Brady, 1983).

Brady (1983) explicam que a estrutura é dada tanto pelo tipo peculiar de agrupamento das partículas predominantes, que como visto é fortemente influenciada pelos microorganismos, como pela textura do solo.

A textura do solo expressa sua característica intrínseca, a proporção entre as diferentes partículas granulométricas, sem as quais não há como falar de estruturação de solos. As classes de textura podem ser areia, areia franca, franco arenosa, franca, franca siltosa, franco argilo arenosa, franco argilosa, franco argilo siltosa, argilo arenosa, argilo siltosa, silte e argila. Essas exprimem a distribuição relativa das partículas do solo de acordo com os respectivos diâmetros (Vieira, 1975).

Não basta apenas que o solo esteja estruturado, mas é preciso que a sua estrutura seja estável, pois somente com uma estrutura estável o solo tem possibilidade de resistir às pressões de alterações no arranjamento da sua estrutura. A deformação da estrutura do solo, ou a sua desestruturação tem uma conseqüência direta na redução da sua porosidade.

Portanto, solos bem estruturados possuem boa porosidade. Segundo Vieira (1975) a porcentagem do espaço de poros encontrada no solo é determinada principalmente pelo seu estado estrutural, ou seja, pela influência correlacionada da textura, composição e agregação das partículas. O aspecto agregação, como visto, é fortemente influenciado pela atividade microbiana.

Vieira (1975) e Brady (1983) explicam que a porosidade do solo é determinada pela distribuição espacial das partículas sólidas no corpo do solo, sendo, portanto, menor a porosidade quanto maior o contato entre essas partículas, o que leva ao conceito de densidade do solo. A porosidade é obtida a partir das determinações da densidade de 
partículas e densidade do solo ou densidade aparente.

$\%$ do espaço poroso $=100-($ densidade aparente $/$ densidade real $) \times 100$

As práticas de cultivo do solo que favoreçam a aproximação entre suas partículas causarão um aumento na densidade do solo e conseqüentemente uma redução no seu espaço poroso ou na sua porosidade. $\mathrm{O}$ incremento no teor de matéria orgânica do solo, por sua vez, tende a reduzir a densidade real do solo (porque tendo a matéria orgânica uma massa específica menor, irá reduzir a massa específica final do conjunto solomatéria orgânica) e pelos benefícios advindos da sua presença na estruturação do solo, a matéria orgânica também reduz a densidade aparente. Portanto, de um modo bem sintético e objetivo, a matéria orgânica atua duplamente no aumento do espaço poroso do solo.

A densidade real do solo é a massa de uma unidade de volume dos sólidos do solo e de acordo com Vieira (1975) e Brady (1983), a matéria orgânica influencia reduzindo o peso específico real do solo, para o qual vale a sinônima densidade real, densidade de partículas. De acordo com Brady (1983) a densidade real de solos puramente minerais varia de 2,5 a 2,75 g.cm ${ }^{-3}$. Com relação ao efeito da matéria orgânica sobre essa propriedade do solo, Vieira (1975) explica, que esses valores de densidade real podem chegar a 1,95 pela ação da matéria orgânica. Para solos originários de rochas básicas (basaltos, diabásio, gabro), entretanto, sem o efeito atenuador da matéria orgânica, os valores de densidade real podem chegar a 3,2 ou mais (Vieira, 1975).

De acordo com Vieira (1975) e Brady (1983) a densidade do solo, para a qual valem os sinônimos densidade aparente e densidade de volume, é a massa de uma unidade de volume do solo, que diferentemente da densidade real, neste caso, volume considera-se o espaço total do solo (volume dos sólidos mais o volume ocupado pelos espaços porosos).

Tendo como objetivo a avaliação da saúde de microbacias, o solo, sendo o elemento chave da escala micro, deve estar funcionalmente apto a resistir à erosão.

De acordo com Gonçalves (2002) os atributos do solo que mais influenciam a sua 
erodibilidade podem ser reunidos em dois grupos: a) aqueles que afetam a sua permeabilidade e a capacidade de armazenamento de água e b) aqueles promovem a resistência do solo à dispersão, ao salpicamento, à abrasão e às forças de transporte do escoamento superficial.

A medida da taxa de infiltração da água no solo (que pode ser expressa, por exemplo, em $\mathrm{mm} \cdot \mathrm{h}^{-1}$ ) é o principal indicador hidrológico da saúde de microbacias hidrográficas, porque a partir desse indicador pode-se avaliar a predominância dos processos hidrológicos na microbacia.

Numa microbacia saudável, predomina o processo de infiltração em detrimento do escoamento superficial.

Alguns indicadores chaves apresentados por Merry (1996) para uma avaliação geral da saúde física do solo são:

- Taxa de infiltração de água

- Agregação e dispersão

- Condição de drenagem

- Porosidade preenchida por ar com a umidade do solo na capacidade de campo

- Água total disponível para as plantas

- Resistência do solo à penetração

Realizando o monitoramento dos indicadores de qualidade do solo, Islam \& Weil (2000) observaram três possíveis agrupamentos dos indicadores quanto à sensibilidade dos mesmos às alterações nas práticas de manejo ou no uso da terra. Alguns dos indicadores monitorados pelos autores estão dispostos na Tabela 5 segundo esses três agrupamentos em questão. Vale ressaltar a semelhança entre este agrupamento e a subdivisão de Walker \& Reuter (1996) quanto aos indicadores de condição e de tendência. 
Tabela 5. Subdivisão de alguns indicadores de qualidade do solo estabilidade apresentada às alterações de manejo (Islam \& Weil, 2000)

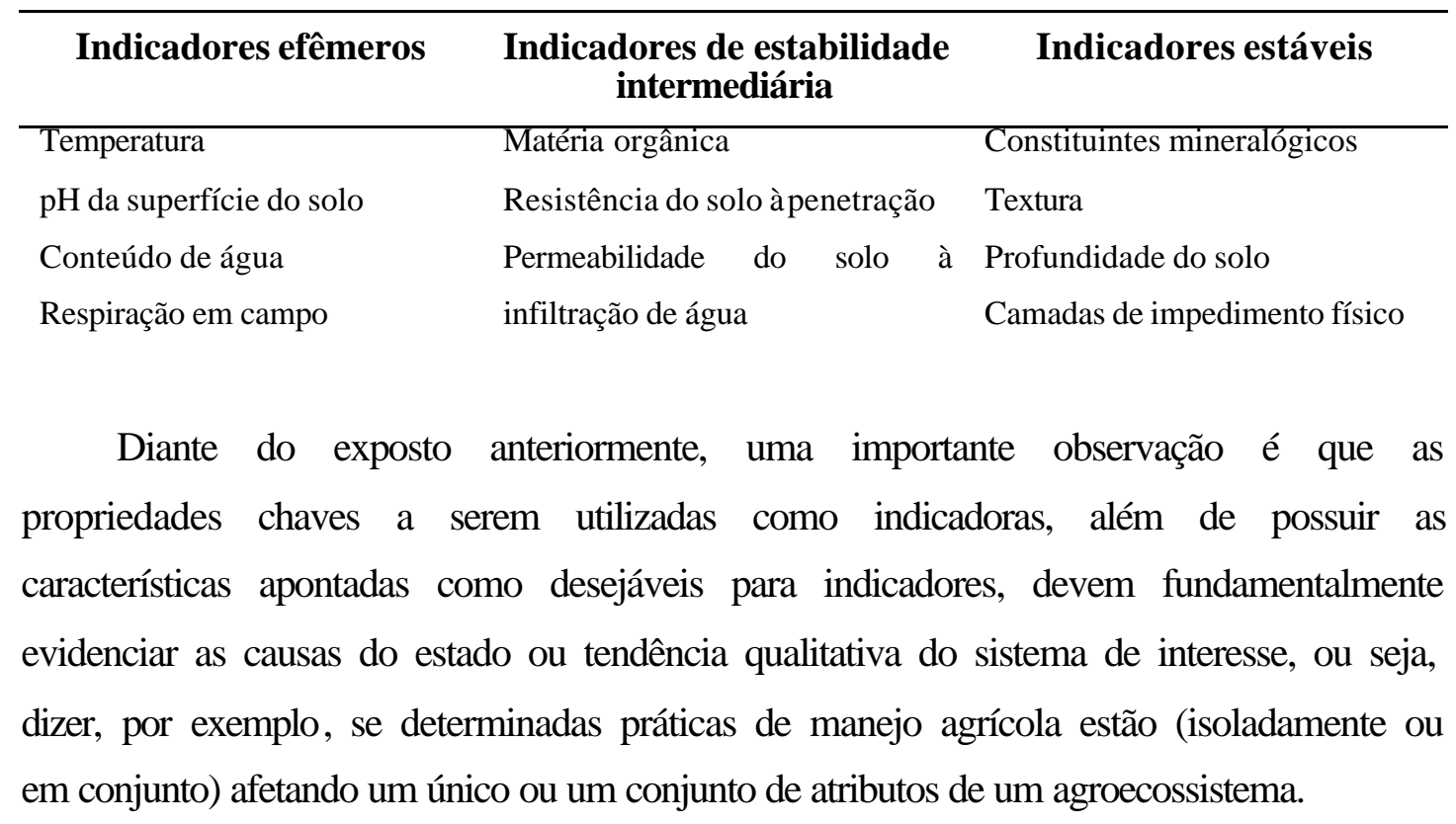




\section{MATERIAL E MÉTODOS}

\section{1 Área de estudo}

A área de estudo do presente trabalho é a microbacia do Rio Passo Cue pertence à Bacia hidrográfica do Paraná III, a qual encontra-se situada na parte oeste da região fisiográfica paranaense denominada $3^{\circ}$ Planalto. A área da microbacia delimitada para o estudo é de 3.120,0 ha, pertence ao município de São Miguel do Iguaçu-PR e é drenada por um curso principal de aproximadamente $5 \mathrm{~km}$ de extensão, compreendido entre as

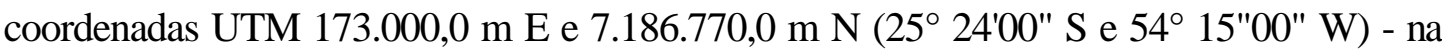
cabeceira - e $167.769,0 \mathrm{~m}$ E e 7.186.645,4518 m N (25⒉ $24^{\prime} 00^{\prime \prime} \mathrm{S}$ e $\left.54^{\circ} 18^{\prime} 12^{\prime \prime} \mathrm{W}\right)$ próximo ao reservatório de Itaipu.

Nesse percurso existem duas estações de coleta de água onde são monitoradas variáveis físicas, químicas e biológicas, sendo esse trabalho feito pelo "Programa de Monitoramento da Qualidade da água dos afluentes da margem esquerda do reservatório de Itaipu". As coordenadas geográficas dessas duas estações, assim como as suas respectivas denominações, entre parênteses, são $25^{\circ} 24^{\prime} 31^{\prime \prime} \mathrm{S}$ e $54^{\circ} 15^{\prime} \quad 48^{\prime \prime} \mathrm{W}$ (nascente) e $25^{\circ} 24^{\prime} 04^{\prime \prime} \mathrm{S}$ e $54^{\circ} 18^{\prime \prime} 04^{\prime \prime} \mathrm{W}$ (jusante), sendo que a primeira representa apenas uma das nascentes formadoras do curso principal. A estação de jusante está localizada a aproximadamente $230 \mathrm{~m}$ à montante do ponto (coordenadas 167.769,0 m E e $7.186 .645,4518 \mathrm{~m} \mathrm{~N}$ ou $25^{\circ} 24^{\prime} 00^{\prime \prime} \mathrm{S}$ e $54^{\circ} 18^{\prime} 12^{\prime \prime} \mathrm{W}$ ) onde arbitrariamente se delimitou a área da microbacia em estudo. Essa última estação situa-se à montante de uma ponte de estrada não pavimentada que liga a BR-277 à vila rural de nome "Cotiporã". 
O fluxo do curso principal se dá predominantemente no sentido sudoeste desde à nascente, onde se encontra a estação E19A2, até a zona de transição do ambiente lótico para lêntico (início da formação do braço do reservatório).

A escolha desta microbacia teve como critérios: i) trata-se de uma microbacia tipicamente agrícola; ii) possui duas estações de monitoramento de qualidade de água, sendo uma em uma das nascentes e outra no final do curso d'água principal; iii) possui área adequada para o objetivo do presente estudo.

Havia ainda um critério, que era a presença do Sistema de Plantio Direto na microbacia do rio Passo Cue, visando com isso a comparação da qualidade do solo entre diferentes sistemas de manejo na própria área de estudo, mas não pode ser contemplado. Apesar disso, foram instaladas parcelas amostrais em uma área de propriedade rural localizada no município de Medianeira-PR, aonde o produtor vem trabalhando em sistema de Plantio Direto há onze anos. Na Figura 4 estão apresentadas, quantitativamente, as repetições de cada tratamento na área de estudo e na área de Plantio Direto, cuja função no trabalho foi fornecer os dados de qualidade de um solo cultivado por longo período (onze anos) em Sistema de Plantio Direto.

O embasamento geológico da região de estudo é constituído por rochas eruptivas básicas, sendo a distribuição dos solos representada predominantemente pela topossequiência Latossolo Roxo, Terra Roxa Estruturada e Brunizem Avermelhado (seguindo do topo para a as partes baixas).

$\mathrm{O}$ uso da terra na microbacia hidrográfica do rio Passo Cue é predominantemente agrícola, contando ainda com algumas agroindústrias, fecularia e frigorífico, todas situadas entre os dois pontos de monitoramento da qualidade da água. As culturas agrícolas dominantes, em consonância com o restante da região lindeira ao lago de Itaipu, são a soja, o milho no verão com o trigo ou aveia no inverno. 


\begin{tabular}{|c|c|c|c|}
\hline \multirow{4}{*}{ Áreas amostradas } & \multicolumn{3}{|c|}{$\begin{array}{c}N^{\circ} \text { de parcelas e } \\
N^{o} \text { de repetições por parcela (entre parênteses) } \\
\text { em cada área amostrada }\end{array}$} \\
\hline & \multirow{2}{*}{\multicolumn{2}{|c|}{$\begin{array}{c}\text { Microbacia do rio Passo Cue } \\
\text { (Área de Estudo) } \\
\text { Área de contribuição com influência direta sobre } \\
\text { a estação de monitoramento: }\end{array}$}} & \multirow{3}{*}{$\begin{array}{l}\text { Área com } \\
\text { Plantio } \\
\text { Direto }{ }^{1}\end{array}$} \\
\hline & & & \\
\hline & Jusante & Nascente & \\
\hline $\begin{array}{l}\text { Cultivo mínimo no Latossolo } \\
\text { (CMLR) }\end{array}$ & $1(9)$ & $1(9)$ & - \\
\hline $\begin{array}{l}\text { Cultivo mínimo na Terra Roxa } \\
\text { (CMTR) }\end{array}$ & $1(9)$ & $1(9)$ & - \\
\hline $\begin{array}{l}\text { Plantio Direto no } \\
\text { Latossolo (PDLR) }\end{array}$ & - & - & $1(9)$ \\
\hline $\begin{array}{ll}\text { Plantio Direto } & \\
\text { na Terra Roxa } & \text { (PDTR) }\end{array}$ & - & - & $1(6)$ \\
\hline $\begin{array}{l}\text { Floresta no Latossolo (FLR) - } \\
\text { testemunha }\end{array}$ & $1(9)$ & - & - \\
\hline $\begin{array}{l}\text { Floresta na Terra Roxa (FTR) } \\
\text { - testemunha }\end{array}$ & $1(9)$ & - & - \\
\hline
\end{tabular}

Figura 4 - Distribuição das parcelas amostras na área de estudo e na área de Plantio

Direto

${ }^{1}$ Área em propriedade rural (Medianeira - PR) sob cultivo em plantio direto há onze anos, localizada fora da microbacia do rio Passo Cue.

A partir de entrevistas abertas, realizadas com os produtores rurais da microbacia e da visita às áreas de amostragem de solo no mês de novembro (cultura da soja em pleno crescimento vegetativo), pode-se caracterizar o manejo para os últimos três anos agrícolas. O manejo predominante nas áreas amostradas constitui-se pelo plantio direto do milho sobre a soja sem o revolvimento do solo com aração e/ou gradagem, fazendose apenas a semeadura sobre o resíduo de palhada da cultura anterior. Ressalta-se que apesar desse sistema ser considerado pelos produtores locais como sendo o Sistema de Plantio Direto na Palha, sabe-se que essa é uma concepção errônea. Portanto, não foi encontrado nesta microbacia área sob o sistema de produção Plantio Direto na Palha conforme já definido e comentado anteriormente. 


\subsection{Componente solo}

\subsubsection{Procedimento de campo}

\subsubsection{Distribuição das parcelas amostrais}

Está largamente difundido na literatura especializada em levantamento de solos, mais especificamente a fotopedologia, que unidades fisiográficas semelhantes possuem solos semelhantes. Por este motivo e pela direta relação existente entre posição no relevo e unidade fisiográfica, pode-se afirmar que para um nível genérico de detalhamento, semelhança há nas propriedades físicas, químicas e mineralógicas e na predominância de processos hidrológicos para uma mesma unidade fisiográfica (Demattê, comunicação pessoal).

Diante disso, a distribuição das parcelas amostrais na microbacia do rio Passo Cue teve como critérios fundamentais:

i) a identificação e delimitação (por meio da fotointerpretação pedológica em visão estereoscópia), das unidades fisiográficas da microbacia;

ii) a área de contribuição (escoamento superficial) com influência direta sobre a qualidade da água no ponto de monitoramento (estações de coleta de água).

Para avaliar a qualidade do solo da área de estudo, dois padrões de referência foram obtidos:

- Solo sob floresta (testemunhas);

- Solo sob manejo de longo prazo (onze anos) com o Sistema de Plantio Direto.

A distribuição das parcelas na área de estudo pode ser visualizada na Figura 5 e a disposição das parcelas em função do tipo de solo e ou posição no relevo pode ser vista na Figura 6. A unidade amostral ou parcela está representada na Figura 7. 


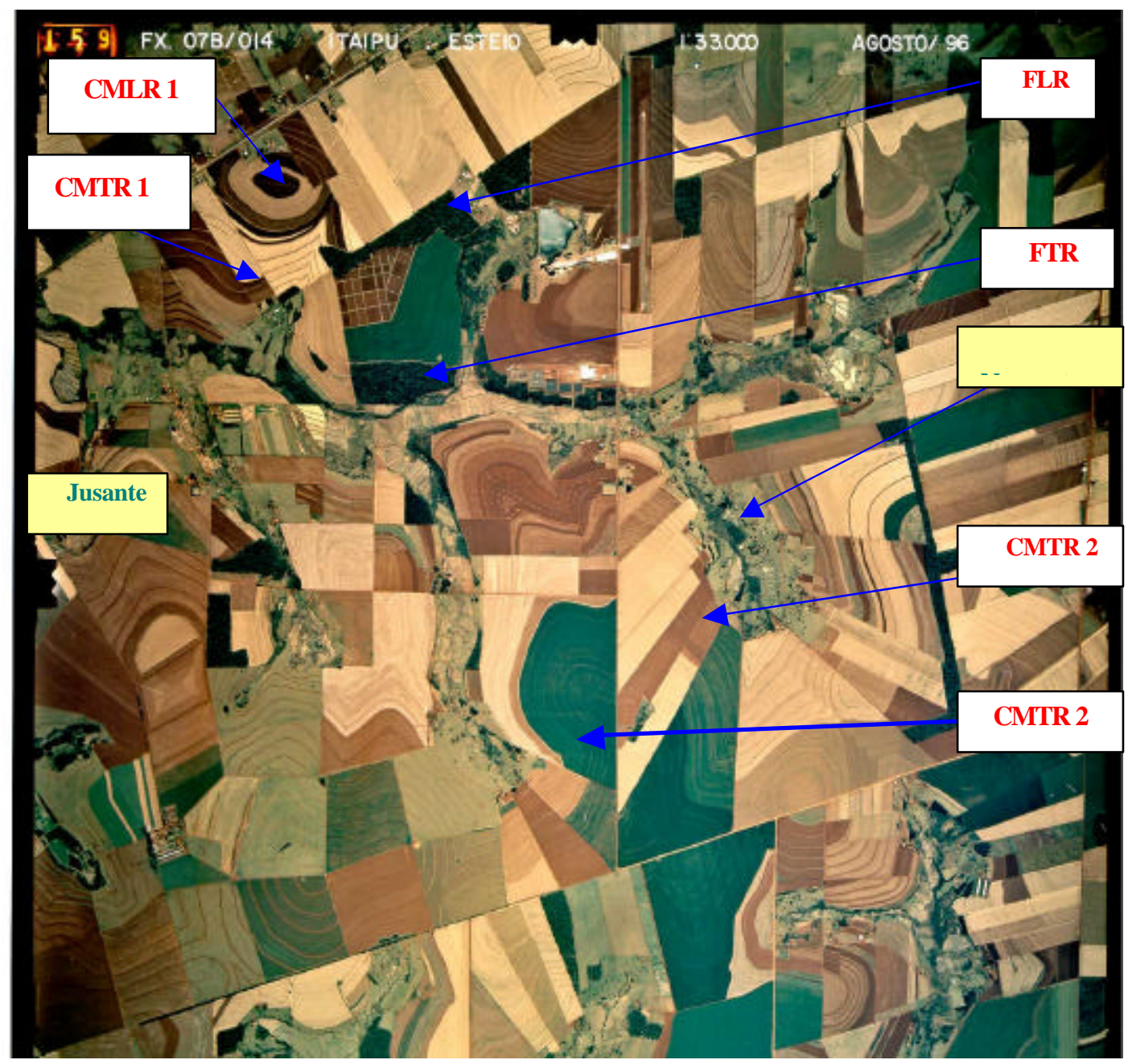

Figura 5 - Fotografia aérea da microbacia do rio Passo Cue com a indicação das parcelas de amostragem de solo e das estações de coleta de água

\section{Onde:}

Nascente/Jusante: Estações de Coleta de água

CMLRn: Enésima repetição da parcela amostral em área de Latossolo Roxo, manejado em sistema de cultivo mínimo com a cultura da soja

CMTRn: Enésima repetição da parcela amostral em área de Terra Roxa Estruturada, manejada em sistema de cultivo mínimo com a cultura da soja 


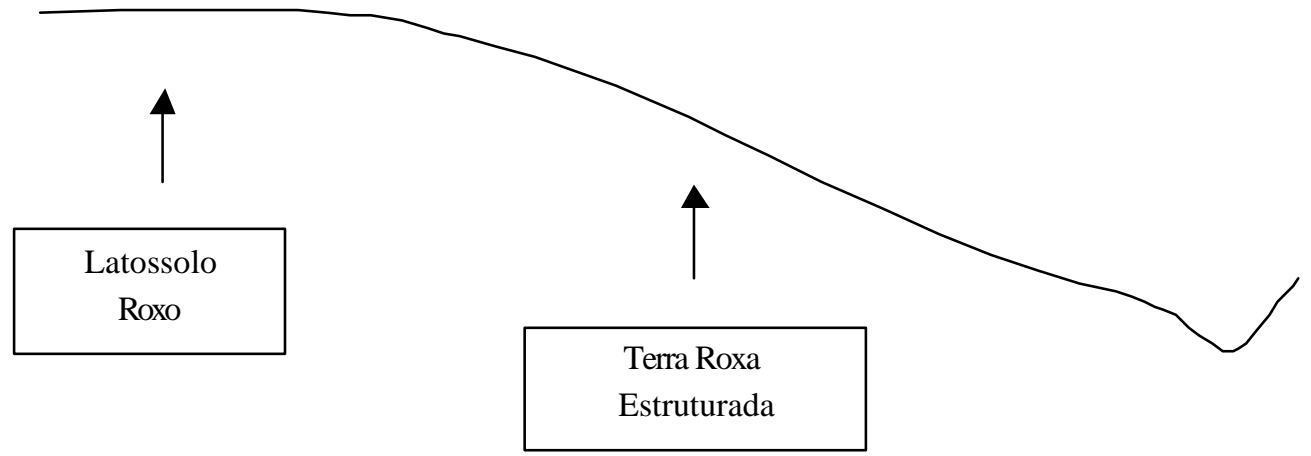

Figura 6 - Esquema da disposição das parcelas na vertente

\begin{tabular}{|ccc|}
\hline $\mathrm{X}$ & $\mathrm{X}$ & $\mathrm{X}$ \\
$\mathrm{X}$ & $\mathrm{X}$ & $\mathrm{X}$ \\
& & \\
$\mathrm{X}$ & $\mathrm{X}$ & $\mathrm{X}$ \\
\hline
\end{tabular}

Figura 7- Unidade amostral ou parcela de 30 x $30 \mathrm{~m}$ com nove repetições

A seqüência de procedimentos para se chegar à locação das parcelas no campo, está apresentada no fluxograma da Figura 8. A partir do mapa base (fotografia aérea), das coordenadas geográficas de cada uma das estações de coleta de água (já que as mesmas não possuem uma identificação física), foi possível, com o auxílio do GPS, identificá-las em campo e conseqüentemente na fotografia aérea. No campo, com o layer unidades fisiográficas traçado em papel de acetato sobreposto á fotografia aérea, chegout se à locação das parcelas. 


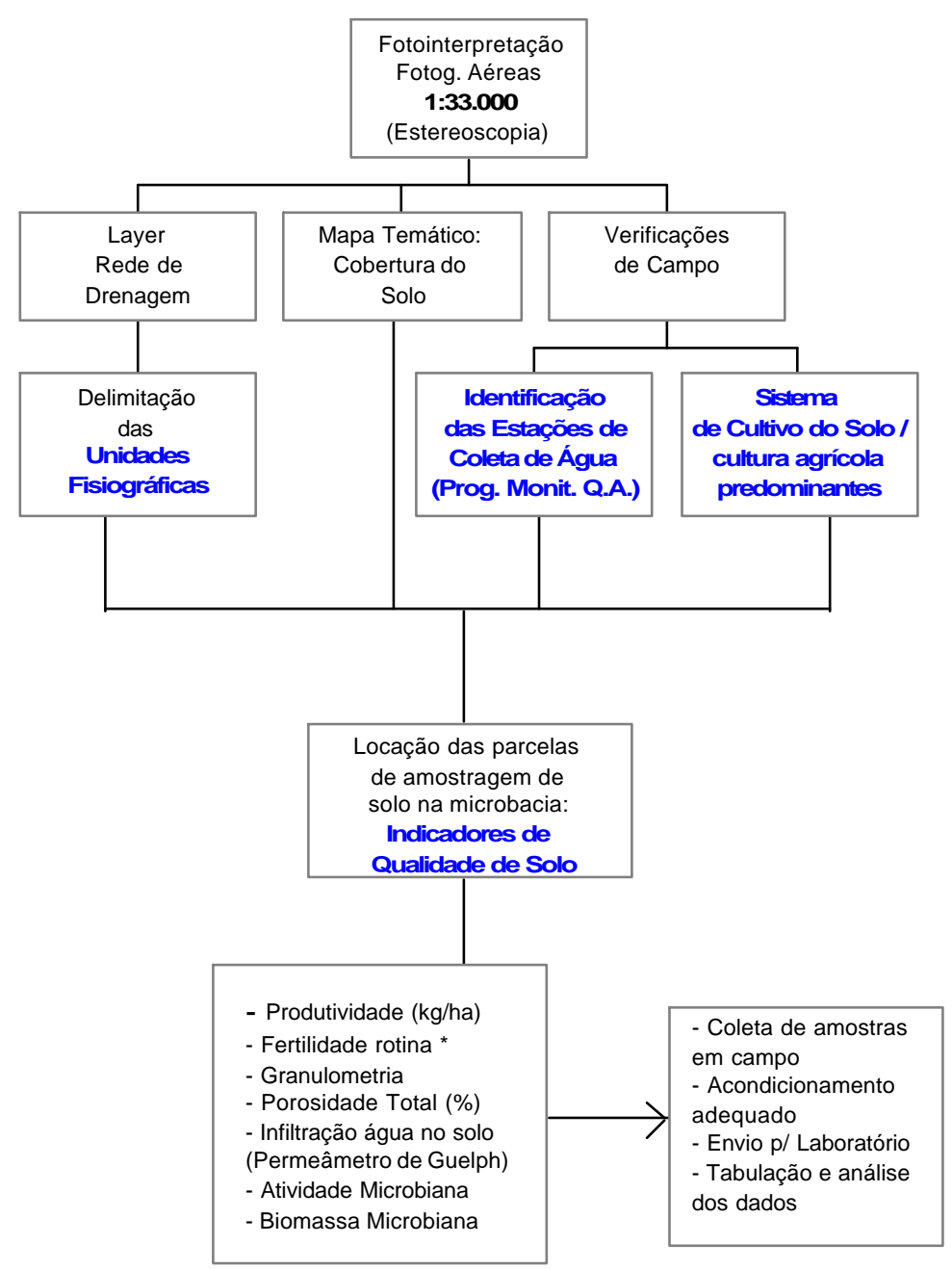

Figura 8 - Sequiência de procedimentos para a alocação das parcelas na área de estudo 


\subsubsection{Coleta de amostras}

As variáveis físicas, químicas e biológicas do solo, determinadas em laboratório a partir da coleta de amostras em campo foram: densidade do solo, densidade de partículas, granulometria, fertilidade química, biomassa microbiana e atividade microbiana.

\section{A) Densidade do solo (Da), densidade real ou de partículas (Dr) e porosidade total do solo (Pt)}

Para a determinação de "Da", "Dr" e "porosidade", realizourse a coleta de solo com anel volumétrico. De cada anel usado para a coleta, retirou-se a respectiva amostra de terra a qual foi acondicionada em saco plástico e identificada, pemanecendo individualizada até o seu descarte pelo laboratório.

Foram amostradas três profundidades $(10 \mathrm{~cm}, 20 \mathrm{~cm}$ e $30 \mathrm{~cm})$ com três repetições em cada subparcela, o que resultou em vinte e sete valores de "Da" e "Dr" por parcela ou 270 ao se considerar a amostragem em toda a microbacia.

\section{B) Fertilidade química, textura, biomassa e respiração basal do solo}

Para todas essas variáveis a coleta foi efetuada com o uso de trado tipo caneco, conforme os procedimentos explicados a seguir.

A cada coleta feita com o trado em uma determinada camada de solo, constituiu-se uma amostra. Em cada subparcela foram obtidas três repetições (três amostras) para cada camada de solo $(0-10 \mathrm{~cm}, 10-20 \mathrm{~cm}$ e $20-40 \mathrm{~cm})$. A fertilidade e textura foram analisadas em todas as camadas, mas a biomassa e a atividade microbiana foram analisadas apenas na camada de $0-10 \mathrm{~cm}$.

As amostras referentes às camadas de $0-10$ e 10 a $20 \mathrm{~cm}$ (180 no total) foram subdivididas no laboratório, para compor as amostras destinadas às análises químicas (separação de 200g), textural (separação de 100g) e microbiológica (separação 75g). 
Todas as 180 amostras receberam os cuidados de acondicionamento e transporte exigidos para análise de variáveis microbiológicas; resfriamento desde a coleta até o destino devido no laboratório, visando evitar a morte dos microorganismos.

Já no caso das amostras referentes à camada de $20-40 \mathrm{~cm}$ (90 no total), das quais separou-se apenas as amostras destinadas às análises química $(200 \mathrm{~g})$ e de textura $(100 \mathrm{~g})$, as mesmas foram secas ao ar e à sombra, visando apenas paralisar os processos de decomposição da matéria orgânica pelos microorganismos.

Nas Figuras de 9 a 13 apresenta-se os procedimentos e equipamentos de campo utilizados para a coleta de amostras conforme explicado nos itens "A" e "B". 


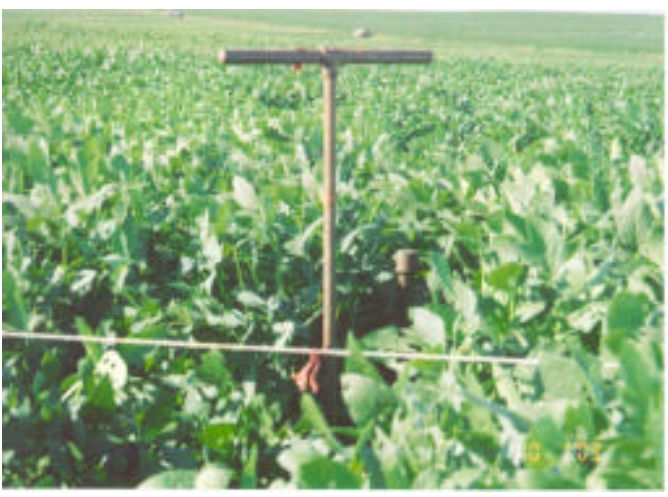

Figura 9 - Visão geral da coleta de amostras na parcela: soja, cultivo mínimo (CMLR2)

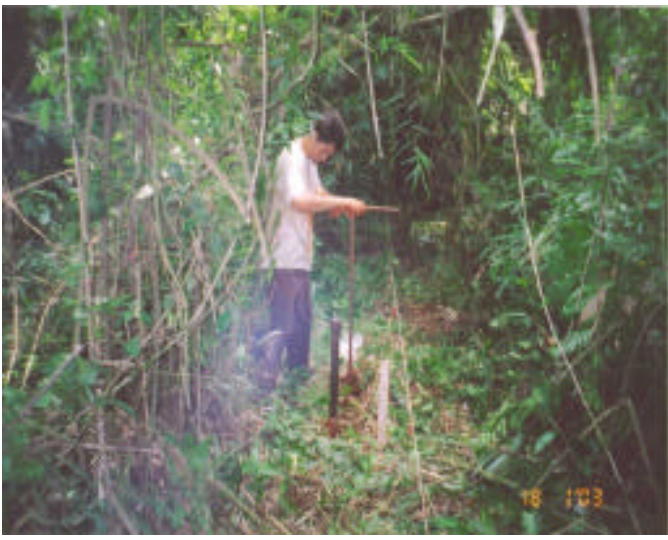

Figura 11 - Visão geral da coleta de amostras em área de fragmento florestal (parcela testemunha - FTR)

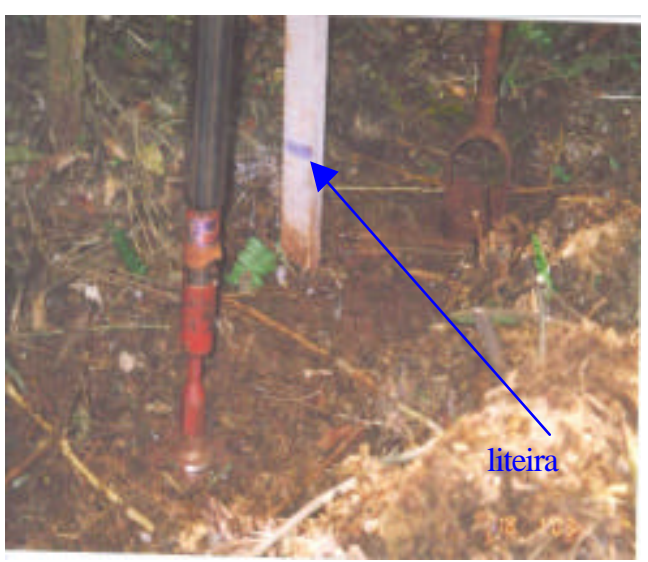

Figura 12 - Detalhe da coleta de amostras na parcela FTR, mostrando a camada de liteira removida da

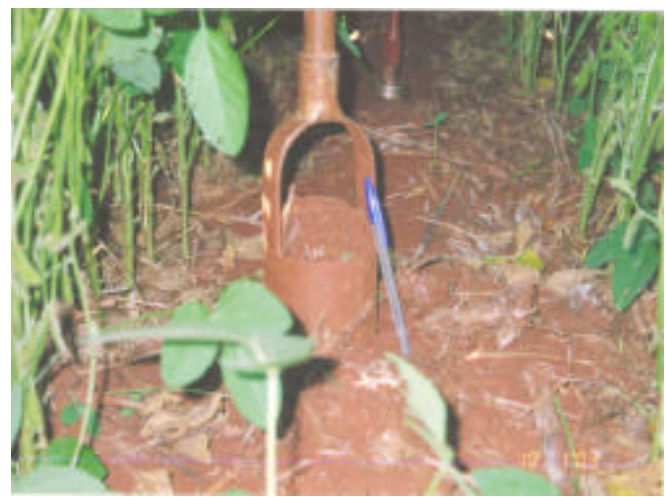

Figura 10 - Detalhe da coleta de amostras na parcela CMLR2 - São Miguel do Iguaçu.

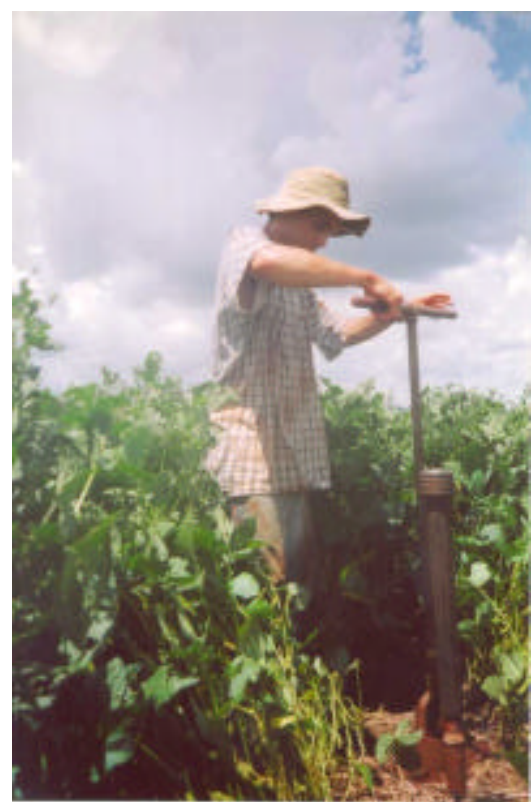

Figura 13 - Detalhe coleta de amostras na parcela: soja Plantio Direto (PDTR) - Medianeira PR 


\subsubsection{Procedimentos de laboratório}

\section{A) Atributos físicos do solo}

Densidade do solo ou densidade aparente (Da ), Densidade real ou de partículas (Dr) e Porosidade total do solo (Pt).

O método utilizado para a determinação de (Da) foi a prova volumétrica (Vieira, 1975; Brady, 1983; Camargo et al., 1986), com a qual determinou-se a relação massa volume. Dividindo-se a massa de solo coletada com o anel volumétrico pelo volume do anel foi determinada Da:

$\mathrm{Da}=$ massa de solo seco / volume de solo $\left(\mathrm{g} \cdot \mathrm{cm}^{-3}\right)$

Para a determinação de (Dr), ou seja, a massa da unidade de volume das partículas primárias do solo, seguiu-se o procedimento descrito em Camargo et al. (1986): pesar 20 $\mathrm{g}$ de terra fina seca em estufa a $105^{\circ} \mathrm{C}$ e transferir-se esta exata quantidade para um balão volumétrico aferido de $50 \mathrm{ml}$. Colocar $25 \mathrm{ml}$ de álcool etílico $96^{\circ} \mathrm{GL}$, agitar delicadamente e deixar em repouso até o dia seguinte. Com o auxílio de bureta, completar o volume do balão com álcool etílico, vagarosamente, a fim de eliminarem bolhas. $\mathrm{O}$ cálculo foi feito pela fórmula abaixo.

$\mathrm{Da}=$ peso da amostra seca / (50 - volume de álcool gasto).

A porosidade total $(\mathrm{Pt})$ percentual do solo foi calculada a partir das determinações de Densidade do solo (Ds) e Densidade de Partículas (Dp) (Vieira, 1975; Brady, 1983; Camargo et al., 1986).

$$
\operatorname{Pt}(\%)=(1-\mathrm{Ds} / \mathrm{Dp}) \times 100
$$




\section{Textura do solo}

A textura do solo expressa a distribuição percentual das partículas primárias e é determinada através da análise granulométrica, que neste estudo seguiu-se o procedimento descrito por Camargo et al. (1986) para o método do densímetro.

\section{B) Atributos biológicos do solo}

\section{Biomassa microbiana do solo}

A partir de uma massa de $10 \mathrm{~g}$ de solo, representativa da camada de 0-10 $\mathrm{cm}$ de profundidade no perfil, foi determinada a biomassa microbiana pelo método fumigaçãoextração seguindo o método (Vance et al., 1987):

\section{Respiração basal}

A respiração basal ou taxa de respiração microbiana foi estimada pela evolução da liberação de $\mathrm{CO}_{2}$ do solo incubado ao longo de oito dias de medições, seguindo o método de Anderson \& Domsh (1993). Segue abaixo:

Pesar $50 \mathrm{~g}$ de solo peneirado com a umidade corrigida para $60 \%$ da capacidade máxima de retenção de água. Coloca-se essa quantidade de solo dentro de frascos de vidro com capacidade de 1,0 litro. No interior destes fracos grandes coloca-se um frasco de $50 \mathrm{ml}$ contendo $10 \mathrm{ml}$ de solução $0,5 \mathrm{~mol} / \mathrm{l}$ de $\mathrm{NaOH}$, a qual tem a função de absorver o $\mathrm{CO}_{2}$ liberado do solo. Durante um período de oito dias em ambiente climatizado a $28{ }^{\circ} \mathrm{C}$, o frasco com a solução de $\mathrm{NaOH}$ é retirado a cada 24 horas de incubação e a ele adiciona-se $1 \mathrm{ml} \mathrm{de} \mathrm{BaCh}_{2}$ e 3 gotas de indicador fenolftaleína. Em seguida procede-se à titulação do excedente de $\mathrm{NaOH}$ com solução de $\mathrm{HCl}$ 0,5 mol// anotando-se a quantidade de $\mathrm{HCl}$ gasto na titulação. A quantidade de $\mathrm{CO}_{2}$ liberado solo, expressa em $\mathrm{mgCO}_{2} \cdot \mathrm{g}^{-1}$ de solo por hora. 


\section{Atributos químicos}

Foi realizada a análise química de rotina com determinação de: $\mathrm{pH}(\mathrm{CaCb})$, matéria orgânica (g. $\left.\mathrm{dm}^{-3}\right)$, Fósforo e Enxofre $\left(\mathrm{mg} \cdot \mathrm{dm}^{-3}\right)$, Potássio, Cálcio, Magnésio, Alumínio, Hidrogênio + Alumínio, Soma de Bases, Capacidade de Troca de Cátions (mmolc, $\mathrm{dm}^{-3}$ ), Saturação de Bases e Saturação por Alumínio (\%).

\subsection{Componente água}

\subsubsection{Estações de monitoramento}

Quanto às variáveis de qualidade de água do deflúvio, para explicar os critérios de sua amostragem, remeteu-se ao Programa de Monitoramento da Qualidade da Água dos Afluentes da Margem Esquerda do Reservatório de Itaipu, de onde os dados foram obtidos. A estruturação do plano de amostragem deste programa considera o fator temporal e espacial, com readequações e redirecionamentos técnicos em ambos os fatores dependendo das informações obtidas pelo monitoramento dos indicadores.

No que tange ao fator temporal, o monitoramento das variáveis físicas e químicas no período de 1996 a 2001 foi semestral nos anos de 1996 e 1997 e trimestral nos demais anos desse mesmo período. Para as variáveis biológicas, tem-se a mesma situação anterior com exceção do ano de 2001, quando a amostragem dos macroinvertebrados bentônicos passou novamente a ser feita semestralmente, como ainda o é atualmente.

Quanto ao seu fator espacial a distribuição das estações de coleta leva em consideração a escolha dos afluentes do reservatório a serem monitorados e o local da estação em cada afluente escolhido.

Os afluentes escolhidos foram àqueles mais representativos em termos de vazão de entrada no reservatório e em termos da área da bacia de contribuição por eles drenada. E com relação à localização das estações de coleta em cada rio monitorado, Loyola (2000) a rede de amostragem procurou estabelecê-las a jusante de eventuais focos de poluição e também, quando possível, o mais próximo do início da formação do braço do 
reservatório, mas onde ainda predomine o regime de fluxo lótico. Quanto mais a jusante da cabeceira, maior é a representatividade dos dados em relação ao efeito do uso e manejo do solo sobre as variáveis físicas, químicas e biológicas diagnosticando, portanto, a qualidade da água que chega no reservatório, informação essa que norteia todo o planejamento e direcionamento inclusive no restabelecimento da rede de amostragem. Entretanto, algumas estações situam-se próximas às cabeceiras visando à comparação com os dados de jusante que contém o efeito do uso da terra na microbacia.

Com relação à amostragem dos macroinvertebrados bentônicos, até 1994 foi feita a coleta tanto em ambientes de fluxo lótico quanto lêntico. Neste referido ano o Programa concluiu a caracterização qualitativa dos grupos taxonômicos que ocorrem na região. Sendo assim, a partir de 1994 as coletas passaram a serem feitas apenas nos ambientes de regime de fluxo lótico com os critérios de amostragem descritos acima, neste mesmo item.

Em conformidade com o exposto, a microbacia do rio Passo Cue possui duas estações de coleta, sendo uma próxima à cabeceira de drenagem (nascente) e outra próxima ao reservatório (jusante), porém ainda com regime de fluxo lótico.

A coleta de amostras foi realizada pela equipe técnica do IAP - Instituto Ambiental do Paraná, no Programa de Monitoramento da Qualidade da Ägua dos Afluentes da Margem Esquerda do Reservatório de Itaipu.

\subsubsection{Obtenção dos dados para a avaliação da qualidade de água}

A avaliação da qualidade da água do deflúvio da microbacia foi feita com base na análise das variáveis físicas, químicas e biológicas ou bioindicadores (macroinvertebrados bentônicos). Todos esses dados foram disponibilizados pelo Programa de Monitoramento da Qualidade da Água dos Afluentes da Margem Esquerda do Reservatório de Itaipu, executado pela parceria entre a Itaipu e o IAP. 


\section{Variáveis físicas e químicas}

As variáveis físicas e químicas da qualidade da água monitoradas no referido programa são: temperatura da água $\left({ }^{\circ} \mathrm{C}\right)$, temperatura do ar $\left({ }^{\circ} \mathrm{C}\right)$, oxigênio dissolvido $(\mathrm{mg}$ $\left(\mathrm{O}_{2} \mathrm{~L}^{-1}\right)$, saturação de oxigênio dissolvido (\%), $\mathrm{pH}$ (unidades), condutividade elétrica ( $\mu \mathrm{S}$ . $\left.\mathrm{cm}^{-1}\right)$, turbidez (NTU), alcalinidade total (mg $\left.\mathrm{CaCO}_{3} \mathrm{~L}^{-1}\right)$, fosfato total (mg $\left.\mathrm{P} . \mathrm{L}^{-1}\right)$, nitrato $\left(\mathrm{mg} \mathrm{NO} \mathrm{NO}_{3} . \mathrm{L}^{-1}\right)$, nitrito $\left(\mathrm{mg} \mathrm{NO} \mathrm{L}^{-1}\right), \mathrm{N}$ amoniacal $\left(\mathrm{mg} \mathrm{NH} \mathrm{N}_{3} . \mathrm{L}^{-1}\right)$, nitrogênio total Kiedahl (mg N. $\left.\mathrm{L}^{-1}\right)$, sólidos em suspensão a $103{ }^{\circ} \mathrm{C}\left(\mathrm{mg} . \mathrm{L}^{-1}\right)$, demanda química de oxigênio $\left(\mathrm{mg} \mathrm{O}_{2} . \mathrm{L}^{-1}\right)$, demanda bioquímica de oxigênio $\left(\mathrm{mg} \mathrm{O}_{2} \mathrm{~L}^{-1}\right)$, dureza total $(\mathrm{mg}$ $\left.\mathrm{CaCO}_{3} \mathrm{~L}^{-1}\right)$.

Com relação à análise dos dados de qualidade de água do deflúvio, sendo esta o reflexo das atividades (cobertura e manejo do solo) na área de contribuição da rede de drenagem, na análise estatística as variáveis que refletem o seu estado qualitativo são consideradas como dependentes. Conseqüentemente, as variáveis que refletem o estado qualitativo do solo da microbacia foram consideradas como sendo independentes. Como se dispunha dos dados de todas as variáveis relacionadas acima, buscou-se por meio da revisão de literatura e da análise de correlação identificar as variáveis de qualidade de água mais adequadas tendo em vista os objetivos do presente estudo.

As variáveis medidas foram comparadas com os parâmetros de qualidade de água da "classe 2" conforme descrito na RESOLUÇÃO do CONSELHO NACIONAL DO MEIO AMBIENTE - CONAMA No 20, DE 18/06/86, ART. $5^{\circ}$.

Para análise da qualidade da água com base nos indicadores biológicos, neste caso, os macroinvertebrados bentônicos, contou-se também com a disponibilização dos dados do Programa de Monitoramento da Qualidade da Água dos Afluentes da Margem Esquerda do Reservatório de Itaipu. 


\section{Meso e microescalas da microbacia do rio Passo Cue}

Nas Figuras de 14 a 19 apresentam-se fotos da área de estudo, as quais estão dispostas de modo a mostrar alguns componentes das diferentes escalas de análise da sustentabilidade, conforme foi abordado anteriormente.

A fotografia aérea (1:33.000) da Figura 14 é um importante mapa base para se estudar na mesoescala, principalmente a condição do ecossistema ripário e o traçado sistema viário, este também representado na Figura 16. A Figura 15 apresenta uma visão do terraceameto agrícola, o qual é fruto de uma intervenção na mesoescala.

Os componentes solo (Figura 17) e água (Figuras 18 e 19) analisados representam um nível micro de análise da sutentabilidade ou da saúde da microbacia, representam, portanto, a microescala. 


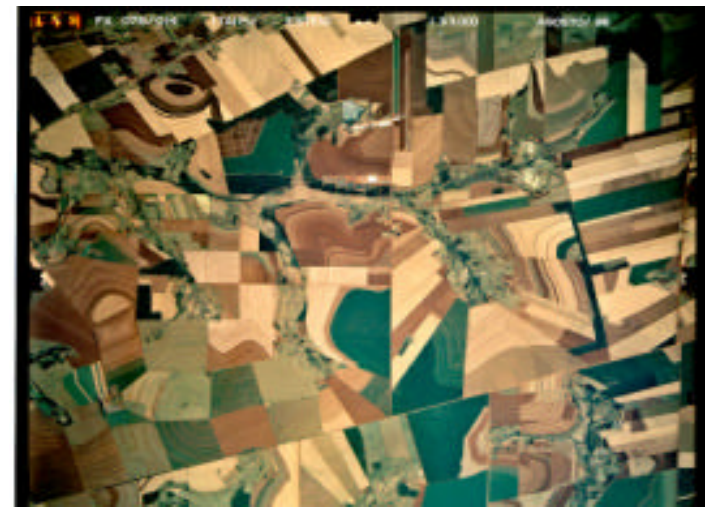

Figura 14 - Ecossistema ripário, terraceamanto, traçado do sistema viário, paisagem etc na escala da microbacia (meso)

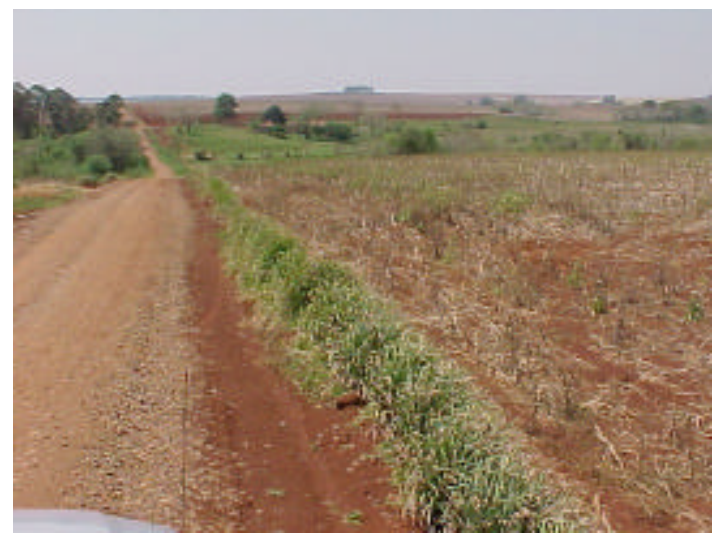

Figura 16 - Sistema viário da microbacia (mesoescala)

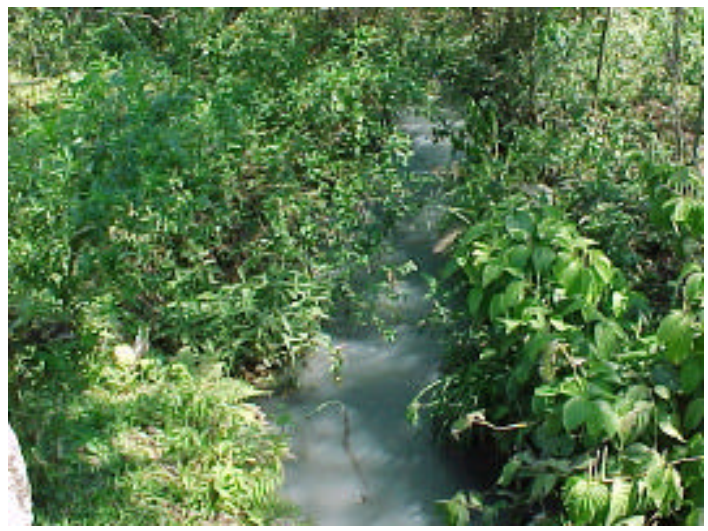

Figura 18 - Detalhe de uma das nascentes do curso principal (microescala)

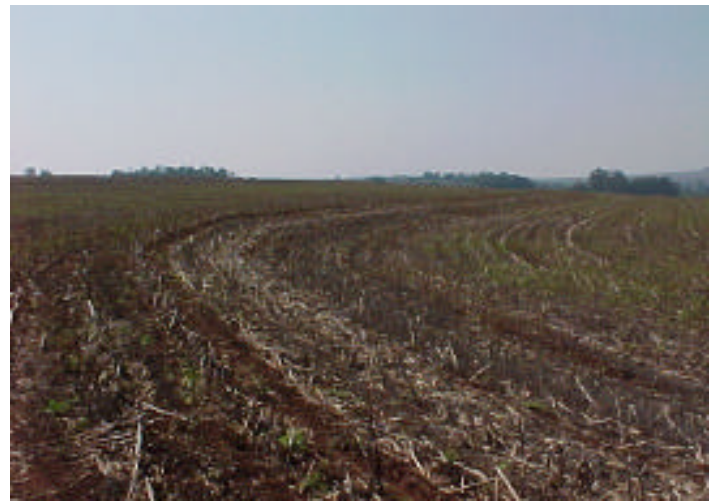

Figura 15 - Terraceamento agrícola (mesoescala)

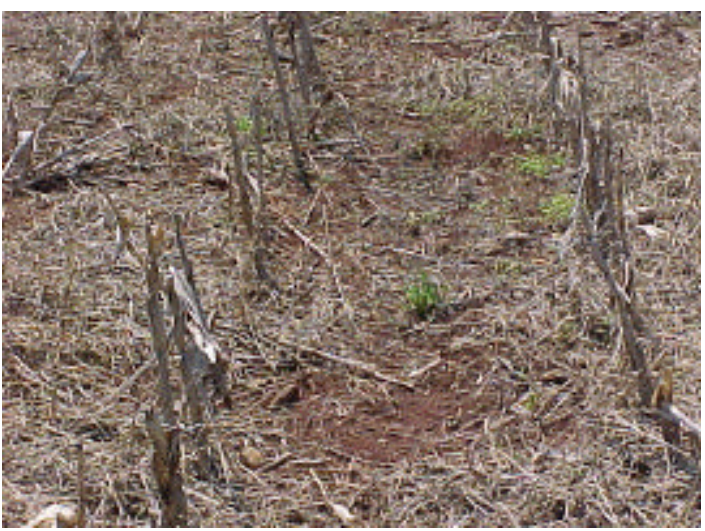

Figura 17 - Gleba de cultivo (microescala)

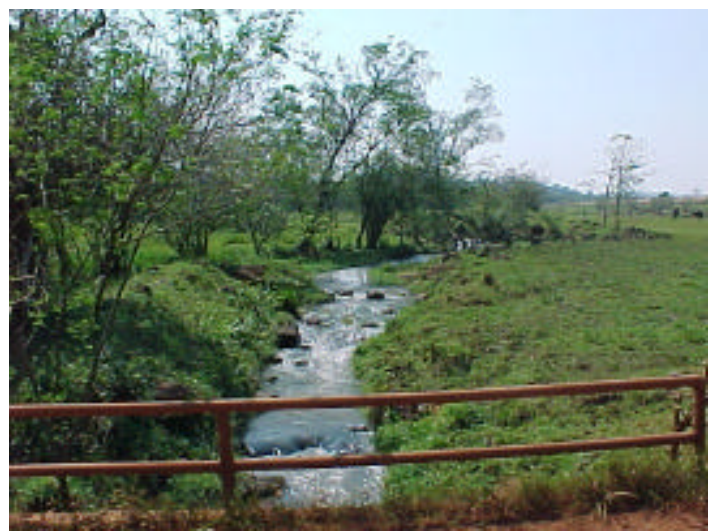

Figura 19 - Detalhe da foz da microbacia (microescala) 
O presente estudo focalizou-se em dois componentes da sustentabilidade da microescala da microbacia do rio Passo Cue, isto é, a qualidade do solo (Figura 4) e a qualidade da água desta microbacia.

\subsection{Análise dos dados}

\subsubsection{Qualidade do solo}

\section{Análise de Componentes Principais (PCA - Principal Componente Analysis)}

A avaliação da qualidade do solo foi feita para os conjuntos de atributos, físicos e biológicos, separadamente, e por fim foi feita uma avaliação com base na análise conjunta dos atributos físicos, químicos e biológicos. Para cada um desses conjuntos de atributos, foram apresentadas estatísticas descritivas e a análise de componentes principais (PCA), foi realizada com o objetivo de ordenar as parcelas.

De acordo com Bini (1999) a Análise de Componentes Principais (PCA) é uma técnica de ordenação que, a partir de um conjunto de variáveis originais, obtém-se índices que expressam a variabilidade dos dados originais, sendo estes índices tanto mais eficientes quanto maior for a sua estrutura de correlação com as variáveis originais. Graficamente, os componentes principais ou fatores que explicam a maior parte da variabilidade dos dados são representados pelos eixos cartesianos. Dessa forma, num gráfico bidimensional estão representados dois componentes principais (ou dois fatores), já num gráfico tridimensional, três componentes. Na PCA a variabilidade dos dados, é portanto, ordenada sobre os componentes principais (eixos) definidos pelo usuário do método.

Ainda segundo Bini, L. M. (comunicação pessoal), três critérios básicos podem ser adotados para a decisão do número de componentes principais ou de fatores que serão retidos para interpretação: 
1) Escolher somente o Fator com autovalores maiores que a unidade ( $>1)$

2) Escolher tantos Fatores ou Componentes até que se consiga explicar 95\% da variância dos dados;

3) Escolher todos os componentes que tenham pelo menos uma variável com loading maior que 0,7 (em módulo).

O mesmo autor ainda explica que o procedimento matemático do protocolo de realização da PCA garante que o primeiro componente principal retido explica ou contém a maior parte da variação total dos dados e o segundo componente da PCA explicará a variação restante dos dados. O primeiro Componente Principal é responsável pela maior discriminação das unidades amostrais de um determinado estudo. Outra importante informação da PCA é que os seus componentes principais não são relacionados entre si, ou seja, a variação dos dados explicada por um dos fatores não o é por um segundo e assim sucessivamente, ou seja, cada fator explica diferentes e excludentes fontes ou causas de variação dos dados. De outra forma, pode-se dizer que as diferentes informações obtidas pela PCA não são redundantes. 


\section{RESULTADOS E DISCUSSÃO}

\subsection{Qualidade do solo}

\subsubsection{Qualidade física}

Na Tabela 6 e na Figura 21 pode-se verificar que o teor médio de argila é alto para todas as áreas estudadas, característico do Latossolo Roxo e Terra Roxa Estruturada. No LR variou de 72,44\% na área sob floresta em São Miguel do Iguaçu (na microbacia do Passo Cue) a 83,11\% na área sob Plantio Direto no município de Medianeira na Bacia do rio Ocoí. Para a TR este mesmo atributo físico em questão variou de 69,33\% na área sob Floresta a 85,83\% na área sob plantio direto. Comparativamente ao LR, manteve-se, portanto, o mesmo comportamento mostrando o maior teor de argila dos solos da área de Medianeira em relação a São Miguel do Iguaçu. Para a comparação entre as áreas da microbacia do rio Passo Cue, verifica-se a predominância de menores teores de argila nas áreas sob floresta, em ambos os solos. Estas observações também podem ser verificadas na Figura 21.

De acordo com Gomes (2000) o coeficiente de variação (CV), expresso em porcentagem, nos experimentos agrícolas pode ser considerado baixo quando for inferior a $10 \%$, médio quando situar-se entre 10 e $20 \%$ e alto para valores entre 20 e $30 \%$ e muito altos quando superiores a $30 \%$. Sendo assim, apenas a área de cultivo mínimo de soja em Terra Roxa Estruturada (CMTR), cujo valor é de 15,76 apresentou um CV considerado médio, sendo todos os demais considerados baixos.

Os valores médios de densidade real e densidade aparente apresentaram baixíssimos coeficientes de variação, conforme pode ser verificado nas Tabelas 7 e 8 . 
Nas Tabela 9 e na Figura 21 pode-se verificar uma tendência decrescente da porosidade dos solos, partindo-se dos maiores valores nas áreas sob floresta, valores intermediários nas áreas sob plantio direto e com menor porosidade encontram-se as áreas sob cultivo mínimo. Conseqüentemente, para a variável densidade aparente a tendência é inversa (Figura 20). Na Figura 21 pode-se observar conjuntamente para todas as áreas amostradas os valores médios obtidos para os atributos físicos em discussão.

Derpsch et al. (1991) comparando diferentes métodos de preparo de solo (convencional com arado de discos, preparo mínimo com escarificador e plantio direto com) na região de Londrina-PR, em Latossolo Roxo e em Terra Roxa Estruturada, verificaram que no sistema de plantio direto as maiores densidades aparentes situavamse em profundidades de $0-20 \mathrm{~cm}$. Ao longo de todo o período que os autores monitoraram essa camada (desde datas precedentes ao preparo até a fase de maturação), foram obtidas maiores densidades aparentes no Plantio direto, em relação aos demais. Ainda segundo os autores, em áreas com densidades aparentes inferiores a 1,20 g.dm não são prováveis problemas de enraizamento ou aeração, limitações estas que começam a surgir com densidades aparentes superiores a $1,25 \mathrm{~g} \cdot \mathrm{cm}^{-3}$. É importante observar que mesmo na camada de $0-10 \mathrm{~cm}$, o solo manejado do sob plantio direto apresentou densidade inferior àárea de cultivo mínimo.

Tabela 6. Estatística descritiva para a variável porcentagem de argila dos solos

\begin{tabular}{lcccccc} 
& CMLR & CMTR & PDLR & PDTR & FLR & FTR \\
\hline Média & 79,72 & 78,67 & 83,11 & 85,83 & 72,44 & 69,33 \\
Erro padrão da média & 0,42 & 0,94 & 0,59 & 0,91 & 0,80 & 1,00 \\
Mediana & 80,00 & 79,50 & 84,00 & 86,00 & 72,00 & 69,00 \\
Moda & 80,00 & 82,00 & 84,00 & 87,00 & 71,00 & 68,00 \\
Desvio Padrão & 1,78 & 3,97 & 1,76 & 2,23 & 2,40 & 3,00 \\
Coeficiente de variação & 3,15 & 15,76 & 3,11 & 4,97 & 5,78 & 9,00 \\
Amplitude & 7,00 & 13,00 & 6,00 & 6,00 & 8,00 & 9,00 \\
Mínimo & 75,00 & 71,00 & 80,00 & 83,00 & 70,00 & 64,00 \\
Máximo & 82,00 & 84,00 & 86,00 & 89,00 & 78,00 & 73,00 \\
No de Observações & 18,00 & 18,00 & 9,00 & 6,00 & 9,00 & 9,00 \\
\hline
\end{tabular}


Tabela 7. Estatística descritiva para a variável densidade real ou densidade de partículas $\left(\mathrm{g} . \mathrm{cm}^{-3}\right)$

\begin{tabular}{lcccccc}
\hline & CMLR & CMTR & PDLR & PDTR & FLR & FTR \\
\hline Média & 2,80 & 2,77 & 2,61 & 2,68 & 2,64 & 2,65 \\
Erro padrão da média & 0,01 & 0,01 & 0,02 & 0,03 & 0,03 & 0,02 \\
Mediana & 2,80 & 2,78 & 2,60 & 2,69 & 2,67 & 2,67 \\
Moda & 2,78 & 2,82 & 2,60 & 2,67 & 2,70 & 2,67 \\
Desvio Padrão & 0,06 & 0,06 & 0,07 & 0,09 & 0,08 & 0,05 \\
Coeficiente de variação & 0,00 & 0,00 & 0,01 & 0,01 & 0,01 & 0,00 \\
Amplitude & 0,22 & 0,19 & 0,24 & 0,25 & 0,24 & 0,14 \\
Mínimo & 2,67 & 2,67 & 2,50 & 2,53 & 2,50 & 2,60 \\
Máximo & 2,89 & 2,86 & 2,74 & 2,78 & 2,74 & 2,74 \\
Soma & 50,40 & 49,92 & 23,49 & 16,09 & 23,73 & 23,88 \\
Número de observações & 18,00 & 18,00 & 9,00 & 6,00 & 9,00 & 9,00 \\
\hline
\end{tabular}

Tabela 8. Estatística descritiva para a variável densidade aparente ou densidade do solo $\left(\mathrm{g} . \mathrm{cm}^{-3}\right)$

\begin{tabular}{lcccccc}
\hline & CMLR & CMTR & PDLR & PDTR & FLR & FTR \\
\hline Média & 1,27 & 1,38 & 1,12 & 1,09 & 0,85 & 0,95 \\
Erro padrão da média & 0,03 & 0,02 & 0,01 & 0,03 & 0,03 & 0,02 \\
Mediana & 1,28 & 1,39 & 1,12 & 1,06 & 0,82 & 0,94 \\
Moda & 1,22 & 1,41 & 1,12 & 1,06 & 0,82 & - \\
Desvio Padrão & 0,14 & 0,08 & 0,04 & 0,08 & 0,08 & 0,07 \\
Coeficiente de variação & 0,02 & 0,01 & 0,00 & 0,01 & 0,01 & 0,00 \\
Amplitude & 0,49 & 0,23 & 0,14 & 0,23 & 0,23 & 0,21 \\
Mínimo & 1,05 & 1,26 & 1,07 & 1,01 & 0,74 & 0,86 \\
Máximo & 1,54 & 1,49 & 1,21 & 1,24 & 0,97 & 1,07 \\
Soma & 22,86 & 24,78 & 10,12 & 6,52 & 7,68 & 8,54 \\
No de observações & 18,00 & 18,00 & 9,00 & 6,00 & 9,00 & 9,00 \\
\hline
\end{tabular}


Tabela 9. Estatística descritiva para a variável porosidade do solo (\%)

\begin{tabular}{lcccccc}
\hline & CMLR & CMTR & PDLR & PDTR & FLR & FTR \\
\hline Média & 54,70 & 50,32 & 56,89 & 59,46 & 67,64 & 64,22 \\
Erro padrão da média & 1,03 & 0,79 & 0,63 & 1,23 & 0,90 & 0,94 \\
Mediana & 55,05 & 50,00 & 57,41 & 60,26 & 67,58 & 64,79 \\
Moda & - & 50 & - & - & - & - \\
Desvio Padrão & 4,36 & 3,33 & 1,90 & 3,02 & 2,71 & 2,82 \\
Coeficiente de variação & 19,03 & 11,10 & 3,62 & 9,13 & 7,33 & 7,97 \\
Amplitude & 16,08 & 9,29 & 5,38 & 8,10 & 8,52 & 8,22 \\
Mínimo & 46,15 & 45,32 & 53,46 & 54,07 & 64,07 & 59,93 \\
Máximo & 62,23 & 54,61 & 58,85 & 62,17 & 72,59 & 68,15 \\
Soma & 984,58 & 905,78 & 512,03 & 356,75 & 608,78 & 577,95 \\
No de observações & 18,00 & 18,00 & 9,00 & 6,00 & 9,00 & 9,00 \\
\hline
\end{tabular}




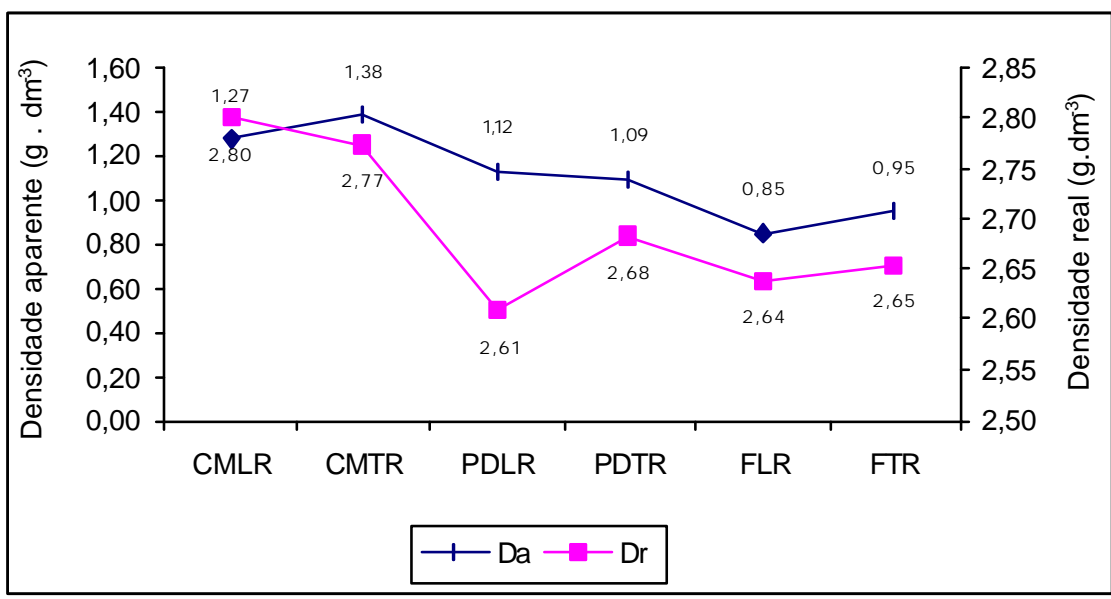

Figura 20 - Valores médios da densidade aparente e da densidade rela para cada uma das áreas amostradas

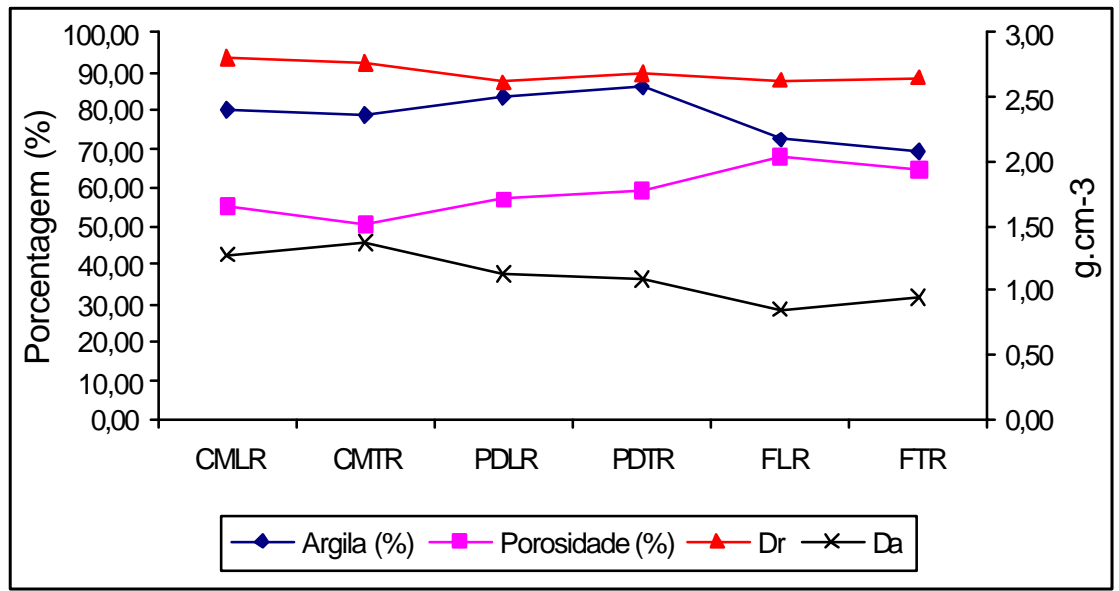

Figura 21 - Valores médios do teor de argila, da porosidade, da densidade real e da densidade aparente para cada uma das áreas amostradas 


\section{Análise de Componentes Principais para os atributos físicos}

Analisando-se a Tabela 10 (segunda coluna da esquerda para a direita), pode-se verificar que o primeiro componente principal explica 73,3\% da variação dos dados e que o segundo componente principal explica $21,4 \%$.

Analisando os valores modulares dos loadings da Tabela 11, pode-se verificar que as variáveis que influenciam mais fortemente o agrupamento dos tratamentos em função do Componente Principal 1 são a densidade aparente (Da), a densidade real (Dr) e a porosidade do solo. No caso do Fator 2, a variável que mais explica os agrupamentos é o teor de argila do solo.

Tratando-se primeiramente da discussão do Componente Principal 1, ao observar os valores reais da Tabela 11, verifica-se que a variável densidade aparente está positivamente relacionada com este eixo (Componente Principal 1) (Figura 22), ao passo que a variável porosidade está negativamente relacionada com o eixo em questão. Isto significa que, neste eixo, a densidade do solo aumenta da esquerda para a direita, enquanto que a porosidade diminui neste mesmo sentido.

Para esta análise simplificada da qualidade física do solo, isto é, considerando apenas esses quatro atributos (valores médios do teor de argila, da densidade de partículas ou densidade real, da densidade do solo e da porosidade), pode-se afirmar que, dentre as áreas consideradas neste trabalho, fisicamente, o melhor solo é aquele sob floresta, seguido pelo solo que há onze anos vem sendo manejado sob o sistema de plantio direto com rotação de culturas e por último, o solo que vem sendo manejado sob o sistema de cultivo mínimo sem rotação de culturas. Outra informação importante que se pode extrair dos resultados acima e da Figura 22 é que os tratamentos avaliados estão agrupados em função do tipo de sistema de manejo do solo, e não em função do tipo de solo avaliado, não se identificando, na camada de 0-10 cm, diferenças físicas entre o Latossolo Roxo e Terra Roxa Estruturada.

Passando a discutir o Componente Principal 2 e considerando o que já foi exposto, verifica-se que o teor de argila aumenta de cima para baixo, já que esta variável está negativamente relacionada com o eixo. Portanto, dentre as três unidades amostrais 
avaliadas a área localizada no município de Medianeira na sub-bacia do rio Ocoi, manejada sob o sistema de Plantio Direto, apresentou maior teor de argila.

Tabela 10. Autovalores da PCA para os atributos físicos do solo

\begin{tabular}{lcccc}
\hline Fatores & Autovalores & $\begin{array}{c}\text { \% total da } \\
\text { Variação dos } \\
\text { dados }\end{array}$ & $\begin{array}{c}\text { Autovalores } \\
\text { Acumulado }\end{array}$ & $\begin{array}{c}\text { Acumulado } \\
\text { \% }\end{array}$ \\
\hline 1 & 2,93 & 73,31 & 2,93 & 73,31 \\
2 & 0,85 & 21,39 & 3,80 & 94,70 \\
3 & 0,21 & 5,29 & 3,99 & 99,99 \\
4 & $3,56 \mathrm{E}-05$ & 0,00089 & 4 & 100 \\
\hline
\end{tabular}

Tabela 11. Coeficientes de Estrutura da PCA

\begin{tabular}{lcccc}
\hline & Factor & Factor & Factor & Factor \\
& $\mathbf{1}$ & $\mathbf{2}$ & $\mathbf{3}$ & $\mathbf{4}$ \\
\hline ARGLA & 0,61 & $-0,76$ & 0,20 & $3,31 \mathrm{E}-05$ \\
DR & 0,79 & 0,53 & 0,31 & $-0,0008$ \\
DA & 0,98 & 0,079 & $-0,15$ & 0,0045 \\
POROS & $-0,97$ & 0,024 & 0,23 & 0,0038 \\
Expl.Var & 2,93 & 0,86 & 0,21 & $3,56 \mathrm{E}-05$ \\
Prp.Totl & 0,73 & 0,21 & 0,053 & $8,9 \mathrm{E}-06$ \\
\hline
\end{tabular}

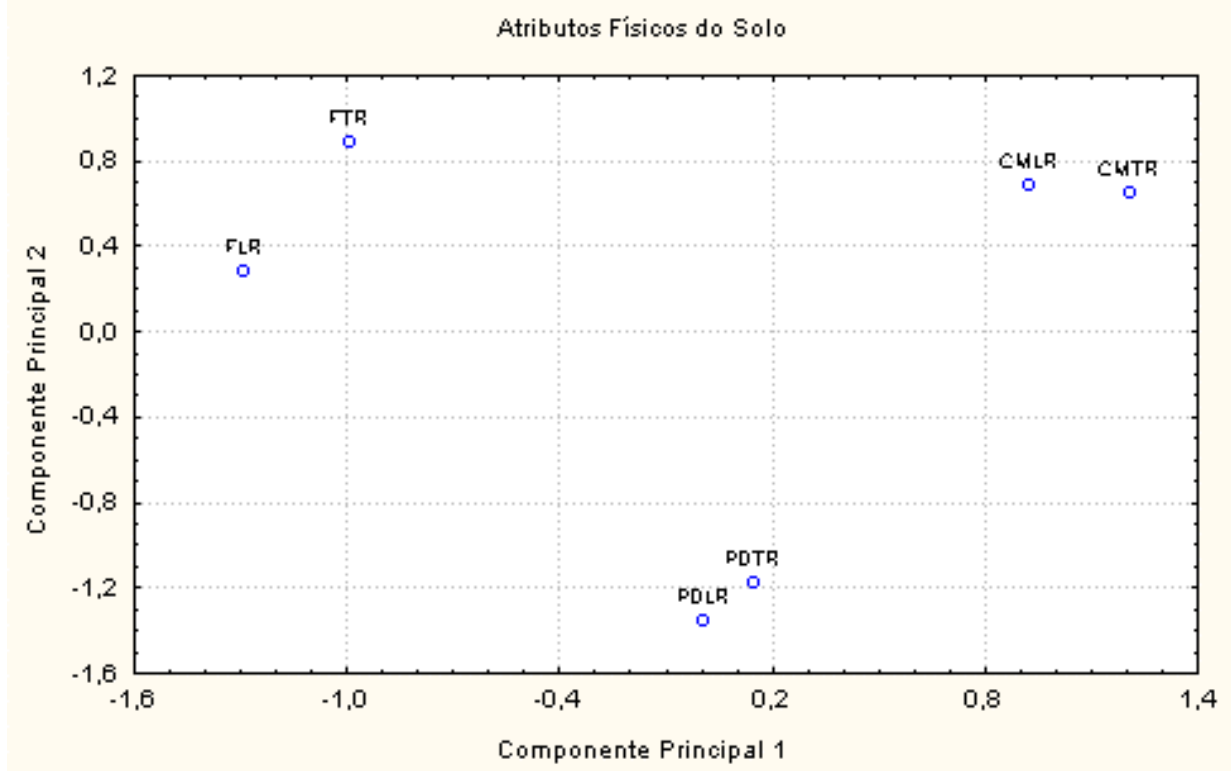

Figura 22 - Escores dos tipos de solo e manejo nos dois primeiros componentes principais obtidos com os atributos atributos físicos do solo 


\section{Análise de Componentes Principais para os atributos físicos e biológicos do solo sem considerar as variáveis relacionadas com a respirometria do solo.}

Ao se realizar a PCA para atributos físicos (argila, densidade real, densidade aparente e porosidade) e biológicos do solo (carbono orgânico do solo e carbono da biomassa microbiana) conjuntamente, porém sem considerar as variáveis relacionadas a respirometria do solo, chega-se às mesmas conclusões obtidas pela PCA aplicada apenas aos atributos físicos, indicando que esses atributos contribuem para a qualidade do solo no mesmo sentido. Estes resultados podem ser verificados nas Tabelas 12 e 13 e na Figura 23. Na Tabela 12 observa-se que o Componente Principal 1 explica 74,2\% da variação dos dados, enquanto que o segundo Componente Principal explica 18,5\%. No Componente Principal 1 as variáveis que explicam mais fortemente os agrupamentos das áreas estudadas são Dr, Da, porosidade, Corg e CB, sendo Dr e Da, negativamente relacionadas com o eixo e as demais, ao contrário, são positivamente relacionadas. Para o segundo Componente Principal, a variável teor médio de argila é a que mais explica os agrupamentos e está negativamente relacionada com esse eixo.

Analisando-se a Figura 23 com base nessas informações, verifica-se que a densidade média de partículas e a densidade aparente média diminuem da esquerda para a direita no eixo do primeiro Componente Principal, ao passo que as variáveis porosidade média, teor médio de carbono orgânico e teor médio de carbono da biomassa aumentam nesse sentido.

A qualidade do solo, avaliada por esses atributos físicos e biológicos corrobora a avaliação feita com base apenas pelos atributos físicos, ou seja, dentre as áreas estudadas, a área que vem sendo cultivada sob o sistema de plantio direto com rotação de culturas há onze anos, apresenta-se em condição intermediária entre a área sob floresta (melhor qualidade do solo) e a área sob cultivo mínimo sem rotação de culturas (pior qualidade do solo). 
Tabela 12. Autovalores da PCA para os atributos físicos e biológicos do solo

\begin{tabular}{lcccc}
\hline Fatores & Autovalores & $\begin{array}{c}\text { \% do total } \\
\text { Variação dos } \\
\text { dados }\end{array}$ & $\begin{array}{c}\text { Autovalores } \\
\text { Acumulado }\end{array}$ & $\begin{array}{c}\text { Acumulado } \\
\text { \% }\end{array}$ \\
\hline 1 & 4,451585 & 74,19309 & 4,451585 & 74,19309 \\
2 & 1,108553 & 18,47588 & 5,560138 & 92,66896 \\
3 & 0,320634 & 5,343907 & 5,880772 & 98,01287 \\
4 & 0,118476 & 1,974606 & 5,999249 & 99,98748 \\
5 & 0,000751 & 0,012523 & 6 & 100 \\
\hline
\end{tabular}

Tabela 13. Coeficientes de Estrutura da PCA para os atributos físicos e biológicos do solo

\begin{tabular}{lccccc}
\hline \multicolumn{1}{c}{ Variáveis } & Fator & Fator & Fator & Fator & Fator \\
& $\mathbf{1}$ & $\mathbf{2}$ & $\mathbf{3}$ & $\mathbf{4}$ & $\mathbf{5}$ \\
\hline ARGLA & $-0,68234$ & 0,699845 & $-0,14325$ & 0,15483 & $-0,01186$ \\
DR & $-0,76255$ & $-0,59276$ & $-0,12109$ & 0,229023 & 0,006024 \\
DA & $-0,95793$ & $-0,13887$ & 0,250935 & $-0,01001$ & $-0,00381$ \\
POROS & 0,946657 & 0,030298 & $-0,31686$ & 0,049944 & 0,005446 \\
C_ORG & 0,905642 & $-0,41532$ & 0,05182 & 0,064635 & $-0,02152$ \\
CB & 0,877808 & 0,273331 & 0,345537 & 0,18783 & 0,008186 \\
Expl.Var & 4,451585 & 1,108553 & 0,320634 & 0,118476 & 0,000751 \\
Prp.Totl & 0,741931 & 0,184759 & 0,053439 & 0,019746 & 0,000125 \\
\hline
\end{tabular}

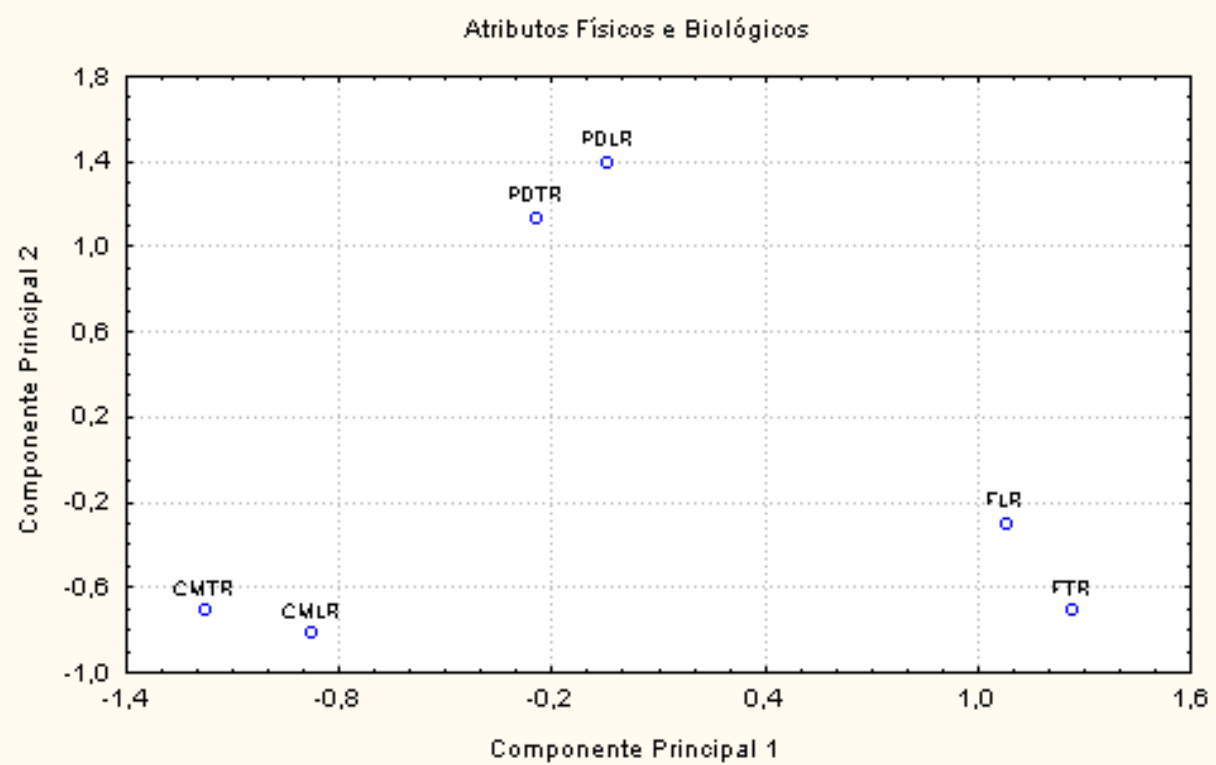

Figura 23 - Escores dos tipos de solo e manejo nos dois primeiros componentes principais obtidos com os atributos atributos físicos e biológicos do solo 


\subsubsection{Qualidade biológica}

\section{Carbono orgânico do solo}

Na Tabela 14 está apresentada a estatística descritiva para o Corg do solo.

Tabela 14. Estatística descritiva para o Carbono orgânico do solo $\left(\mathrm{mg}_{\mathrm{g}} \mathrm{g}^{-1}\right)$

\begin{tabular}{lrrrrrr}
\hline & CMLR & CMTR & PDLR & PDTR & FLR & FTR \\
\hline Média & 28,40 & 22,45 & 29,67 & 30,02 & 59,52 & 60,19 \\
Erro padrão da média & 1,11 & 0,72 & 0,31 & 0,79 & 2,30 & 2,68 \\
Mediana & 27,97 & 21,25 & 30,00 & 30,66 & 60,00 & 57,45 \\
Desvio Padrão & 4,73 & 3,04 & 0,93 & 1,92 & 6,91 & 8,05 \\
Coeficiente de variação & 22,35 & 9,27 & 0,86 & 3,70 & 47,75 & 64,73 \\
Amplitude & 15,61 & 9,74 & 2,74 & 5,07 & 21,10 & 21,63 \\
Mínimo & 21,43 & 18,62 & 28,10 & 26,61 & 50,53 & 50,47 \\
Máximo & 37,04 & 28,36 & 30,84 & 31,68 & 71,62 & 72,09 \\
Soma & 511,21 & 404,14 & 267,05 & 180,14 & 535,64 & 541,72 \\
Número de observações & 18,00 & 18,00 & 9,00 & 6,00 & 9,00 & 9,00 \\
\hline
\end{tabular}

\section{Biomassa microbiana}

Na Tabela 15 está apresentada a estatística descritiva para a biomassa microbiana do solo (mg C. $\mathrm{g}^{-1}$ de solo).

Tabela 15. Estatística descritiva para a biomassa microbiana do solo (mg C $\cdot \mathrm{g}^{-1}$ de solo)

\begin{tabular}{lcccccc}
\hline & CMLR & CMTR & PDLR & PDTR & FLR & FTR \\
\hline Média & 0,08 & 0,07 & 0,17 & 0,15 & 0,16 & 0,23 \\
Erro padrão da média & 0,01 & 0,01 & 0,02 & 0,02 & 0,04 & 0,02 \\
Mediana & 0,10 & 0,08 & 0,17 & 0,14 & 0,13 & 0,22 \\
Moda & 0,11 & 0,01 & 0,17 & 0,11 & 0,01 & 0,26 \\
Desvio Padrão & 0,05 & 0,05 & 0,05 & 0,05 & 0,13 & 0,07 \\
Coeficiente de variação & 0,00 & 0,00 & 0,00 & 0,00 & 0,02 & 0,00 \\
Amplitude & 0,14 & 0,14 & 0,14 & 0,12 & 0,40 & 0,24 \\
Mínimo & 0,01 & 0,01 & 0,10 & 0,11 & 0,01 & 0,13 \\
Máximo & 0,15 & 0,15 & 0,24 & 0,23 & 0,41 & 0,37 \\
Soma & 1,48 & 1,28 & 1,57 & 0,89 & 1,41 & 2,10 \\
Nímero de Observações & 18,00 & 18,00 & 9,00 & 6,00 & 9,00 & 9,00 \\
\hline
\end{tabular}




\section{Respiração basal}

Na Tabela 16 está apresentada a estatística descritiva para a biomassa microbiana do solo (mg C.g ${ }^{-1}$ de solo). Na Figura 24 pode-se verificar o comportamento das variáveis Cor, $\mathrm{q}_{\mathrm{CO}_{2}}$ e $\mathrm{q}_{\text {microb }}$ entre os diferentes sistemas de manejo.

Tabela 16. Estatística descritiva para a biomassa microbiana do solo ( $\mathrm{mg} \mathrm{C} \cdot \mathrm{g}^{-1}$ de solo)

\begin{tabular}{lcccccc}
\hline & CMLR & CMTR & PDLR & PDTR & FLR & FTR \\
\hline Média & 0,30 & 0,39 & 0,24 & 0,27 & 0,23 & 0,51 \\
Erro padrão da média & 0,04 & 0,06 & 0,03 & 0,06 & 0,05 & 0,07 \\
Mediana & 0,26 & 0,36 & 0,27 & 0,26 & 0,16 & 0,41 \\
Desvio Padrão & 0,16 & 0,25 & 0,09 & 0,14 & 0,16 & 0,21 \\
Coeficiente de variação & 0,02 & 0,06 & 0,01 & 0,02 & 0,03 & 0,04 \\
Amplitude & 0,56 & 1,01 & 0,26 & 0,39 & 0,52 & 0,59 \\
Mínimo & 0,14 & 0,08 & 0,13 & 0,13 & 0,12 & 0,31 \\
Máximo & 0,70 & 1,09 & 0,39 & 0,52 & 0,64 & 0,90 \\
Soma & 5,42 & 7,09 & 2,19 & 1,60 & 2,07 & 4,59 \\
Número de observações & 18 & 18 & 9 & 6 & 9 & 9 \\
\hline
\end{tabular}

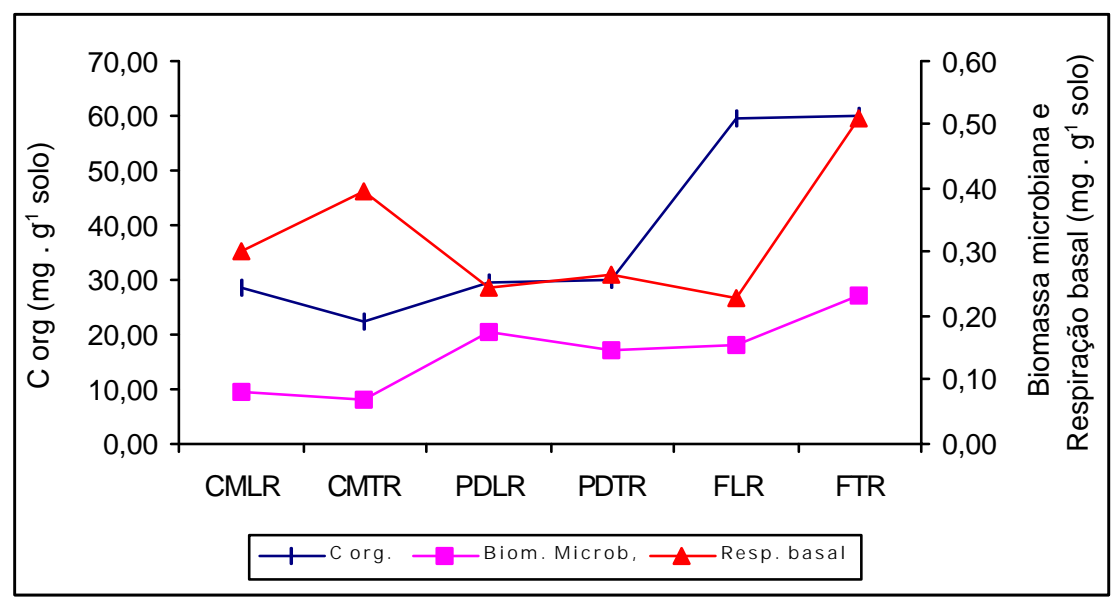

Figura 24 - Comparação dos atributos físicos nos diferentes sistemas de manejo 


\section{Quociente metabólico}

Na Tabela 17 está apresentada a estatística descritiva para o quociente metabólico do solo

Tabela 17. Estatística descritiva para o quociente metabólico do solo

\begin{tabular}{lcccccc}
\hline & CMLR & CMTR & PDLR & PDTR & FLR & FTR \\
\hline Média & 2,29 & 3,73 & 0,40 & 0,54 & 1,37 & 0,69 \\
Erro padrão da média & 0,68 & 0,98 & 0,06 & 0,13 & 0,57 & 0,16 \\
Mediana & 0,96 & 2,59 & 0,38 & 0,47 & 0,39 & 0,43 \\
Desvio Padrão & 2,88 & 4,15 & 0,18 & 0,33 & 1,71 & 0,48 \\
Coeficiente de variação & 8,29 & 17,23 & 0,03 & 0,11 & 2,92 & 0,23 \\
Amplitude & 9,18 & 13,55 & 0,61 & 0,87 & 4,14 & 1,41 \\
Mínimo & 0,38 & 0,25 & 0,17 & 0,21 & 0,11 & 0,28 \\
Máximo & 9,56 & 13,79 & 0,78 & 1,09 & 4,25 & 1,68 \\
Soma & 41,19 & 67,06 & 3,64 & 3,22 & 12,29 & 6,23 \\
Número de observações & 18 & 18 & 9 & 6 & 9 & 9 \\
\hline
\end{tabular}

\section{Quociente microbiano}

Na Tabela 18 está apresentada a descritiva para o quociente microbiano do solo.

Tabela 18. Estatística descritiva para o quociente microbiano do solo

\begin{tabular}{lcccccc}
\hline & CMLR & CMTR & PDLR & PDTR & FLR & FTR \\
\hline Média & 0,003011 & 0,003277 & 0,005883 & 0,004901 & 0,002749 & 0,003876 \\
Erro padrão da média & 0,000425 & 0,00057 & 0,000517 & 0,000528 & 0,000841 & 0,000325 \\
Mediana & 0,003269 & 0,003078 & 0,005873 & 0,004387 & 0,002011 & 0,003648 \\
Desvio Padrão & 0,001805 & 0,002419 & 0,00155 & 0,001294 & 0,002523 & 0,000974 \\
Coeficiente de variação & $3,26 \mathrm{E}-06$ & $5,85 \mathrm{E}-06$ & $2,4 \mathrm{E}-06$ & $1,67 \mathrm{E}-06$ & $6,37 \mathrm{E}-06$ & $9,49 \mathrm{E}-07$ \\
Amplitude & 0,005515 & 0,006514 & 0,004812 & 0,003478 & 0,007953 & 0,002914 \\
Mínimo & 0,000276 & 0,000371 & 0,003333 & 0,003781 & 0,000162 & 0,002576 \\
Máximo & 0,005791 & 0,006885 & 0,008145 & 0,007259 & 0,008115 & 0,00549 \\
Soma & 0,054191 & 0,058991 & 0,052946 & 0,029408 & 0,024738 & 0,034881 \\
Número de observações & 18 & 18 & 9 & 6 & 9 & 9
\end{tabular}


$\mathrm{Na}$ Figura 25 pode-se observar a diferença entre o quociente metabólico e o quociente microbiano nos diferentes sistemas de manejo, onde o plantio direto apresenta os menores valores em ambos os casos.

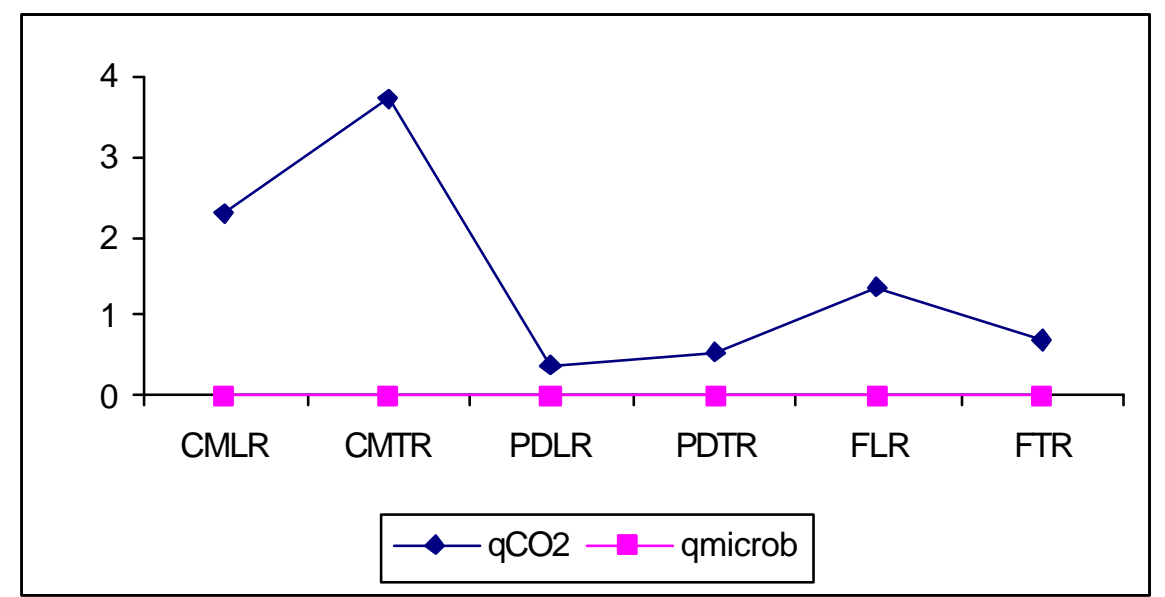

Figura 25 - Comparação entre o quociente metabólico e o quociente microbiano nos diferentes sistemas de manejo

\section{Análise de Componentes Principais com todos os atributos biológicos considerados neste estudo.}

Os resultados da PCA para os atributos biológicos do solo apresentados nas Tabelas 19 e 20 mostram que o Componente Principal 1 explica 44,23 \% da variação dos dados, o Componente Principal 2, 38,8\% e o Componente Principal 3, 16,06\%. De acordo com os critérios para se decidir o número de Fatores ou Componentes Principais da PCA que devem ser retidos, tem-se: i) reter tantos os fatores até que se consiga explicar no mínimo 95\% da variação dos dados; ii) que se escolha somente os Fatores com autovalores maiores que 1,0 e iii) que se escolha todos os Fatores que possuam pelo menos uma variável com loading maior que 0,7. Analisando-se as Tabelas 19 e 20, pode-se verificar que os três critérios não são satisfeitos simultaneamente. Adotando-se os critérios “ii” e "iii”, dois Componentes Principais devem ser retidos.

Retendo-se dois Componentes Principais, pode-se verificar pela Tabela 19 que 83,03\% da variação dos dados é explicada. 
Aplicando-se o critério da escolha dos Fatores que possuam variáveis com loading maiores do que 0,7 , na Tabela 20 observa-se que as variáveis que explicam mais fortemente o Fator 1 são Carbono orgânico do Solo (C-org), Carbono da Biomassa (CB), Respiração da biomassa microbiana $\left(\mathrm{CO}_{2}\right)$ e Carbono oriundo da respiração da biomassa $\left(\mathrm{C}-\mathrm{CO}_{2}\right)$, sendo verificado ainda que todas essas variáveis estão positivamente relacionadas com o eixo do Fator 1 ou Componente Principal 1. Com base nessas observações, ao analisar a Figura 26 verifica-se que, para o Componente Principal 1, as áreas PDLR, PDTR, FLR, CMLR e CMTR apresentaram menores teores médios de Corg e $\mathrm{CB}$, assim como menor desprendimento médio de $\mathrm{CO}_{2}$ pela respiração microbiana, em comparação àárea FTR.

Para o Componente Principal 2, as variáveis que explicam mais fortemente os agrupamentos das áreas estudadas são o quociente metabólico do carbono $\left(\mathrm{q}_{\mathrm{CO}}\right)$ e o quociente microbiano $\left(\mathrm{q}_{\text {microb}}\right)$, estando o primeiro positivamente relacionado com o eixo em questão e o segundo, negativamente relacionado. Sendo assim, na Figura 26, o qco2 aumenta de baixo para cima e o quicrob diminui nesta direção, podendo-se identificar três agrupamentos: um formado pelas áreas de plantio direto (PDLR e PDTR), com menor $\mathrm{q}_{\mathrm{CO} 2}$ e maior $\mathrm{q}_{\text {microb}}$; um segundo formado pelas áreas de fragmentos florestais, em condição intermediária para estas duas variáveis e um terceiro grupamento formado pelas áreas de cultivo mínimo, com maior $\mathrm{q}_{\mathrm{CO} 2}$ e menor $\mathrm{q}_{\text {microb}}$.

Para interpretação aplicada destes resultados obtidos pela PCA, deve-se ter clareza do significado destas variáveis ou destes atributos biológicos do solo.

$\mathrm{O}$ quociente metabólico, expresso em quantidade de $\mathrm{CO}_{2}$ liberado pela quantidade de carbono da biomassa em função do tempo, representa a taxa de respiração específica da biomassa microbiana. Quanto maiores forem os valores deste quociente, significa que a população microbiana está oxidando carbono de suas próprias células (respiração de manutenção dos organismos vivos) para a sua manutenção e adaptação ao meio em que se encontra, o solo. Altos valores de $\mathrm{q}_{\mathrm{CO} 2}$ significam, portanto, condições adversas ou estressantes para a população microbiana do solo. Por outro lado, o quociente microbiano, expresso em quantidade de carbono da biomassa microbiana por quantidade de carbono orgânico do solo, representa a quantidade de carbono do solo que 
está imobilizado nas células microbianas, ou seja, condição de crescimento da população microbiana em função de condições favoráveis no meio, no caso, o solo (Anderson \& Domsch, 1993; Sparling, 1992; Bardgett \& Saggar, 1994; Islam \& Weil, 2000; Silva, 2001).

Analisando-se os resultados obtidos pela PCA com base nessas informações, podese concluir, considerando as limitações do delineamento experimental, que sob o ponto de vista da qualidade biológica do solo, avaliada pelos atributos considerados neste estudo, dentre as áreas estudadas, as melhores são aquelas que vem sendo cultivadas há onze anos sob o sistema de plantio direto, estando em condição intermediária as áreas sob fragmentos florestais e em piores condições encontram-se as áreas que vem sendo cultivadas em cultivo mínimo sem rotação de culturas. Esse resultado mostra que o solo nos dois fragmentos florestais tidos como testemunhas encontram-se com a sua microbiota em condições mais estressantes do que a área de soja que vem sendo cultivada há onze anos sob o sistema de plantio direto com rotação de culturas.

Com relação às variáveis teor de Corg do solo, $\mathrm{CB}$, liberação de $\mathrm{CO}_{2}$ e $\mathrm{C}-\mathrm{CO}_{2}$ (carbono quantificado pela liberação de $\mathrm{CO}_{2}$ ), verifica-se que com exceção da área testemunha FTR (fragmento florestal situado na Terra Roxa Estruturada), que apresentou os maiores teores médios de $\mathrm{Corg}, \mathrm{CB}$ liberação de $\mathrm{CO}_{2}$ e $\mathrm{C}-\mathrm{CO}_{2}$, todas as demais apresentaram-se num mesmo grupamento, ou seja, encontram-se em condições semelhantes com relação a essas variáveis.

Tabela 19. Autovalores da PCA para os atributos biológicos do solo

\begin{tabular}{lcccc}
\hline & Eigenval & $\begin{array}{c}\text { \% total } \\
\text { Variance }\end{array}$ & $\begin{array}{c}\text { Cumul. } \\
\text { Eigenval }\end{array}$ & $\begin{array}{c}\text { Cumul. } \\
\text { \% }\end{array}$ \\
\hline 1 & 2,653807 & 44,23011 & 2,653807 & 44,23011 \\
2 & 2,328175 & 38,80292 & 4,981982 & 83,03303 \\
3 & 0,963634 & 16,06056 & 5,945616 & 99,09359 \\
4 & 0,052158 & 0,869301 & 5,997774 & 99,9629 \\
5 & 0,002226 & 0,037105 & 6 & 100 \\
\hline
\end{tabular}


Tabela 20. Coeficientes de Estrutura da PCA para os atributos biológicos do solo

\begin{tabular}{lccccc}
\hline & Factor & Factor & Factor & Factor & Factor \\
& $\mathbf{1}$ & $\mathbf{2}$ & $\mathbf{3}$ & $\mathbf{4}$ & $\mathbf{5}$ \\
\hline C_ORG & 0,829496 & $-0,02771$ & 0,553708 & 0,061623 & $-0,02789$ \\
CB & 0,784893 & $-0,60839$ & 0,070111 & 0,088763 & 0,031744 \\
CO2 & 0,781632 & 0,506663 & $-0,36203$ & $-0,03577$ & $-0,00033$ \\
C_CO2 & 0,781324 & 0,509627 & $-0,3586$ & $-0,03488$ & $-0,00136$ \\
Q_CO2 & $-0,35574$ & 0,915925 & $-0,0647$ & 0,174147 & 0,003712 \\
Q_MICROB & $-0,04142$ & $-0,77584$ & $-0,62312$ & 0,087516 & $-0,02062$ \\
Expl.Var & 2,653807 & 2,328175 & 0,963634 & 0,052158 & 0,002226 \\
Prp.Tot1 & 0,442301 & 0,388029 & 0,160606 & 0,008693 & 0,000371 \\
\hline
\end{tabular}

Conforme mostra a Tabela 19, ao se reter três Componentes Principais para a análise dos atributos biológicos do solo, obtém-se a explicação de 99,2\% da variação dos dados, assim ordenadas: 44,25\% explicada pelo Componente Principal 1, 38,8\% pelo Componente Principal 2 e 16,06\% pelo terceiro Componente Principal. Observa-se na Figura 26 que, as variáveis $\mathrm{Corg}, \mathrm{CB}, \mathrm{CO}_{2}$, e $\mathrm{C}-\mathrm{CO}_{2}$ explicam os grupamentos em função do primeiro Componente Principal, estando todas positivamente relacionadas com o seu eixo. A variável $\mathrm{qCO}_{2}$, por sua vez explica os agrupamentos em função do segundo Componente Principal, estando também positivamente relacionada com o eixo. Por fim a variável q-microb explica os agrupamentos em função do terceiro Componente Principal.

Novamente verifica-se que para as variáveis que explicam o Primeiro Componente Principal (Corg, $\mathrm{CB} \mathrm{CO}_{2}$ e $\mathrm{C}-\mathrm{CO}_{2}$ ), as áreas plantio direto, cultivo mínimo e aquela sob fragmento florestal no Latossolo Roxo, são qualitativamente semelhantes, com menores valores médios desses atributos em comparação com a área de fragmento florestal da Terra Roxa Estruturada. Com relação ao quociente metabólico, que explica a ordenação das áreas em função do segundo Componente Principal, observa-se que o solo que apresenta as condições mais adversas à microbiota é aquele sob cultivo mínimo, seguido pelas áreas de fragmentos florestais (em condição intermediária) e as condições mais favoráveis à micobiota foram encontradas nos solos sob plantio direto com rotação de culturas. Nos três grupamentos manteve-se a tendência de melhores condições (menor 
quociente metabóilico) no Latossolo Roxo em Relação à Terra Roxa. Para o terceiro Componente Principal, quociente microbiano (indicador de condições menos perturbadas) as melhores condições qualitativas do solo, com base nesse atributo, foram encontradas nas duas áreas de plantio direto e também na área sob cultivo mínimo da Terra Roxa Estruturada, sendo seguidas pela área de cultivo mínimo no Latossolo, fragmento florestal na Terra Roxa e em piores condições a área de fragmento localizada no Latossolo Roxo.

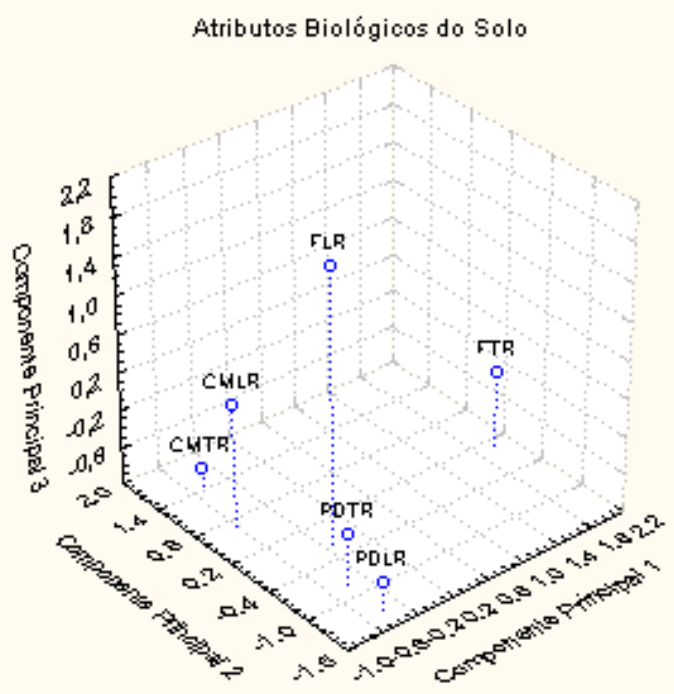

Figura 26 - Escores dos tipos de solo e manejo nos três primeiros componentes principais obtidos com os atributos biológicos do solo 


\section{Análise de Componentes Principais com todos os atributos físicos e todos os atributos biológicos do solo, considerados neste estudo}

Aplicando-se a PCA para todos os atributos físicos e biológicos do solo conjuntamente, retendo-se três componentes principais, explicando, portanto, 95,9\% da variação dos dados seguem as seguintes observações. Na Tabela 21 verifica-se que o Componente Principal 1 explica 49,9\% do total da variação dos dados, o segundo Componente Principal, 31,97\% e o terceiro Componente Principal, por sua vez, explica $15,28 \%$ do total. Para o Componente Principal 1 as variáveis que explicam mais fortemente os agrupamentos dos dados são dr, da, $\mathrm{qCO}_{2}$ (todas positivamente relacionadas com o eixo) e porosidade, Corg, e CB (todas negativamente relacionadas com o eixo). As variáveis teor de argila (positivamente relacionada com o eixo) e $\mathrm{CO}_{2}$, $\mathrm{C}-\mathrm{CO}_{2}$ (negativamente relacionadas com o eixo), são aquelas que explicam a ordenação dos agrupamentos ao longo do segundo componente principal. O terceiro componente principal ordena os agrupamentos das áreas em função da variável qmicrob (positivamente relacionada com o eixo).

Com base nisso, analisando-se o eixo do Componente Principal 1 da Figura 27, considerando o que já foi discutido com relação ao significado aplicado de cada uma dessas variáveis, e ainda dentro das limitações do delineamento experimental, observase que as áreas sob cultivo mínimo sem rotação de culturas encontram-se em condição de maiores densidades médias de partículas e aparente, menor porosidade nédia, maior quociente metabólico médio, menores teores médios de Corg e CB, indicando predominar as condições adversas à microbiota do solo nessas áreas, em comparação às áreas sob plantio direto, em condição intermediária para esses atributos e as áreas testemunhas (fragmentos florestais), as quais apresentaram as melhores condições qualitativas do solo, segundo esses atributos analisados pelo Componente Principal 1.

No eixo do segundo Componente Principal, ainda na Figura 27, verifica-se novamente os maiores teores médios de argila nas áreas de plantio direto (ressalta-se aqui o que foi exposto na discussão da Figura 22, quanto ao teor de argila). A liberação de $\mathrm{CO}_{2}$ foi maior nas áreas de cultivo mínimo e no fragmento florestal localizado na 
Terra Roxa Estruturada, menor nas áreas de plantio direto, ficando a área do fragmento florestal do Latossolo Roxo em condição intermediária para esse atributo e também para o teor médio de argila, os quais explicam a ordenação dos agrupamentos neste eixo.

No terceiro Componente Principal (Figura 27), explicado pela variável qmicrob, verifica-se que as áreas de plantio direto, assim como a área de fragmento florestal e cultivo mínimo em Terra Roxa apresentam-se com altos valores deste quociente. Corroborando os resultados obtidos pela PCA aplicada somente aos atributos biológicos, a área de fragmento florestal na Terra Roxa apresentou os menores valores deste quociente.

Tabela 21. Autovalores da PCA para os atributos físicos e biológicos do solo

\begin{tabular}{lcccc}
\hline & Eigenval & $\begin{array}{c}\text { \% total } \\
\text { Variance }\end{array}$ & $\begin{array}{c}\text { Cumul. } \\
\text { Eigenval }\end{array}$ & $\begin{array}{c}\text { Cumul. } \\
\text { \% }\end{array}$ \\
\hline 1 & 4,990369 & 49,90369 & 4,990369 & 49,90369 \\
2 & 3,197739 & 31,97739 & 8,188108 & 81,88108 \\
3 & 1,52823 & 15,2823 & 9,716338 & 97,16338 \\
4 & 0,226259 & 2,262593 & 9,942598 & 99,42598 \\
5 & 0,057402 & 0,574024 & 10 & 100 \\
\hline
\end{tabular}

Tabela 22. Coeficientes de Estrutura da PCA para os atributos físicos e biológicos do solo

\begin{tabular}{lccccc}
\hline & Factor & Factor & Factor & Factor & Factor \\
& $\mathbf{1}$ & $\mathbf{2}$ & $\mathbf{3}$ & $\mathbf{5}$ & \\
\hline ARGILA & 0,601617 & 0,738307 & 0,21237 & $-0,186$ & $-0,11517$ \\
DR & 0,806385 & $-0,47962$ & $-0,11954$ & $-0,31924$ & 0,059157 \\
DA & 0,947084 & $-0,12285$ & 0,27816 & 0,046162 & 0,091837 \\
POROS & $-0,92353$ & 0,036955 & $-0,35283$ & $-0,11211$ & $-0,09316$ \\
C_ORG & $-0,86229$ & $-0,47105$ & $-0,16257$ & $-0,02787$ & 0,085752 \\
CB & $-0,93288$ & 0,083303 & 0,348941 & $-0,00588$ & 0,031735 \\
CO2 & $-0,16449$ & $-0,8141$ & 0,552165 & $-0,04238$ & $-0,05914$ \\
C_CO2 & $-0,16418$ & $-0,81676$ & 0,548507 & $-0,04148$ & $-0,05808$ \\
Q_CO2 & 0,739874 & $-0,56858$ & $-0,23964$ & 0,253865 & $-0,08621$ \\
Q_MICROB & $-0,11428$ & 0,724005 & 0,674996 & 0,079198 & 0,029389 \\
Expl.Var & 4,990369 & 3,197739 & 1,52823 & 0,226259 & 0,057402 \\
Prp.Tot1 & 0,499037 & 0,319774 & 0,152823 & 0,022626 & 0,00574 \\
\hline
\end{tabular}




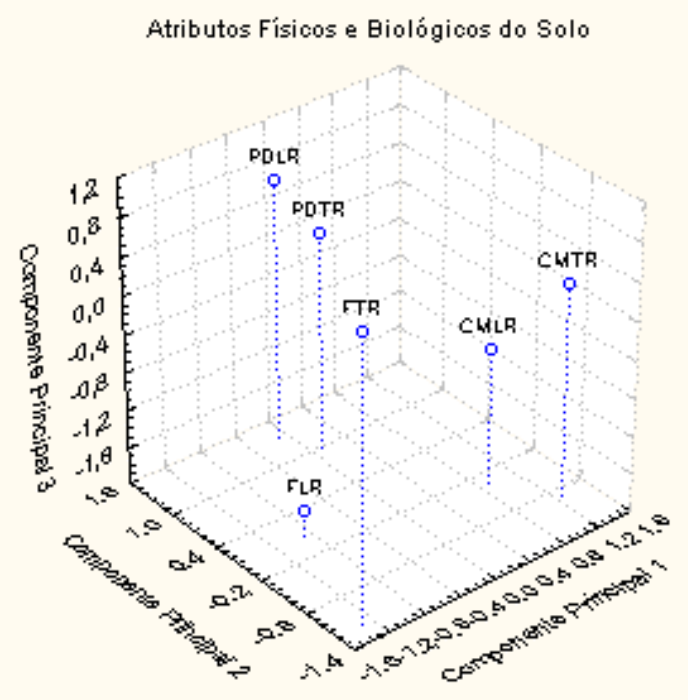

Figura 27 - Escores dos tipos de solo e manejo nos dois primeiros componentes principais obtidos com os atributos físicos e biológicos do solo

\subsubsection{Qualidade física, química e biológica}

\section{Análise de Componentes Principais com atributos físicos, químicos e biológicos do} solo.

Realizando-se a PCA conjuntamente para os atributos físicos, químicos e biológicos considerados neste estudo, retendo-se primeiramente apenas dois Componentes Principais, seguem as observações.

O Componente Principal 1 explica 54,04\% e o Componente Principal 2 explica $28,4 \%$ do total da variação dos dados (Tabela 23). Na Tabela 24, para o primeiro Componente Principal, as variáveis teor médio de argila e densidade aparente média (negativamente relacionadas com o eixo), e as variáveis porosidade média, teores médios de Corg, CB, S, CTC, SB e V\% (positivamente relacionadas com o eixo) são aquelas que explicam mais fortemente a ordenação dos agrupamentos nesse eixo. Para o 
segundo Componente Principal, a densidade média de partículas, quociente metabólico médio (negativamente relacionadas com eixo) e o quociente microbiano médio (positivamente relacionado com o eixo) são as variáveis que explicam mais fortemente a ordenação dos agrupamentos nesse eixo. E a ordenação dos grupamentos em função do terceiro Componente Principal é explicada pelas variáveis $\mathrm{CO}_{2}$ e $\mathrm{C}-\mathrm{CO}_{2}$ (ambas positivamente relacionadas com o eixo).

Com base no exposto, analisando-se a Figura 28, observa-se que, para o Componente Principal 1, os teores médios de argila e a densidade aparente média diminuem da esquerda para a direita, enquanto que a porosidade média e os teores médios de Corg, CB, S, CTC, SB e V\% aumentam nesse mesmo sentido. Assim sendo, com base na análise do primeiro Componente Principal as áreas de cultivo mínimo e plantio direto encontram-se em condições de qualidade do solo semelhantes, diferindo apenas das áreas testemunhas, com melhor qualidade do solo. Nessa PCA conjunta, a diferenciação das áreas de cultivo mínimo e plantio direto é possível apenas por meio do quociente metabólico, densidade real e quociente microbiano, variáveis essas que explicam a ordenação dos agrupamentos no segundo Componente Principal.

Com essa análise multivariada para todos os atributos físicos, químicos e biológicos considerados neste estudo e, tendo em vista o significado dos quocientes metabólico e microbiano, esses resultados mostram que as áreas de cultivo mínimo apresentam condições mais adversas à microbiota do solo se comparadas às áreas de plantio direto, ficando as áreas testemunhas, sob fragmentos florestais, em condição intermediária.

Tabela 23. Autovalores da PCA para os atributos físicos, químicos e biológicos do solo

\begin{tabular}{lcccc}
\hline Fatores & Autovalores & $\begin{array}{c}\text { \% total da } \\
\text { Variação dos dados }\end{array}$ & $\begin{array}{c}\text { Autovalores } \\
\text { Acumulado }\end{array}$ & $\begin{array}{c}\text { Acumulado } \\
\text { \% }\end{array}$ \\
\hline 1 & 8,646746 & 54,04216 & 8,646746 & 54,04216 \\
2 & 4,538543 & 28,36589 & 13,18529 & 82,40805 \\
3 & 1,99758 & 12,48488 & 15,18287 & 94,89293 \\
4 & 0,49411 & 3,088186 & 15,67698 & 97,98112 \\
5 & 0,323021 & 2,018883 & 16 & 100 \\
\hline
\end{tabular}


Tabela 24. Coeficientes de Estrutura da PCA para os atributos físicos, químicos e biológicos do solo

\begin{tabular}{lccccc}
\hline \multicolumn{1}{c}{ Variáveis } & Fator & Fator & Fator & Fator & Fator \\
& $\mathbf{1}$ & $\mathbf{2}$ & $\mathbf{3}$ & $\mathbf{4}$ & $\mathbf{5}$ \\
\hline ARGILA & $-0,90579$ & 0,309498 & 0,200006 & 0,208409 & $-0,01776$ \\
DR & $-0,36211$ & $-0,85507$ & 0,101904 & 0,356806 & $-0,00635$ \\
DA & $-0,70811$ & $-0,59164$ & 0,368166 & $-0,05352$ & 0,100654 \\
POROS & 0,742893 & 0,498409 & $-0,41087$ & 0,129783 & $-0,11849$ \\
C_ORG & 0,981184 & 0,06863 & $-0,17786$ & $-0,01045$ & 0,028704 \\
CB & 0,715462 & 0,647759 & 0,218939 & $-0,10912$ & 0,093172 \\
+CO2 & 0,590893 & $-0,45535$ & 0,652625 & $-0,11348$ & $-0,06857$ \\
C_CO2 & 0,592167 & $-0,45844$ & 0,649285 & $-0,11376$ & $-0,06825$ \\
Q_CO2 & $-0,30354$ & $-0,91007$ & $-0,10091$ & $-0,18819$ & $-0,18451$ \\
Q_MICROB & $-0,3279$ & 0,757667 & 0,502249 & $-0,18086$ & 0,182916 \\
PH & 0,836397 & $-0,42264$ & 0,115588 & 0,244717 & 0,220385 \\
P & $-0,27247$ & 0,651006 & 0,60648 & 0,349374 & $-0,10987$ \\
S & 0,880158 & 0,235611 & 0,200654 & 0,035995 & $-0,35812$ \\
CTC & 0,99369 & $-0,0029$ & 0,097862 & 0,0126 & 0,053246 \\
SB & 0,985673 & $-0,12694$ & 0,074511 & 0,037992 & 0,07307 \\
V\% & 0,871965 & $-0,44159$ & $-0,12949$ & 0,113356 & 0,122721 \\
Expl.Var & 8,646746 & 4,538543 & 1,99758 & 0,49411 & 0,323021 \\
Prp.Totl & 0,540422 & 0,283659 & 0,124849 & 0,030882 & 0,020189 \\
\hline & & & & &
\end{tabular}




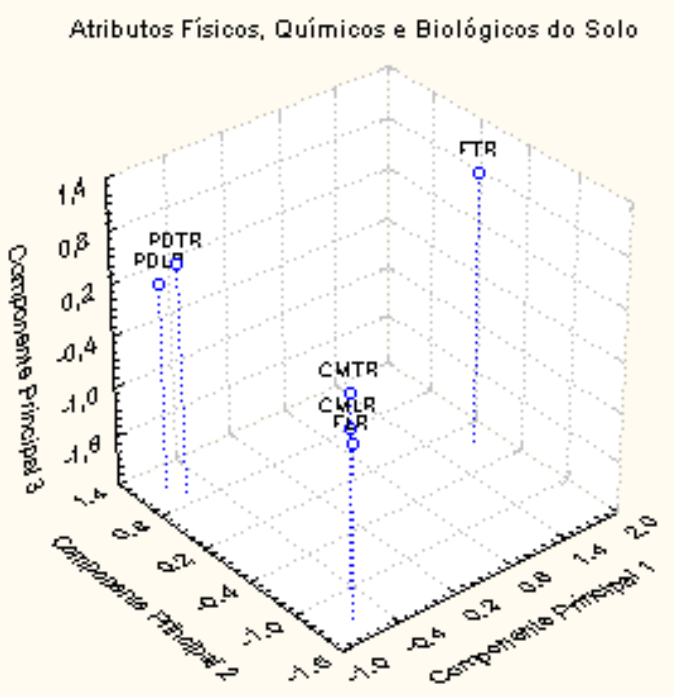

Figura 28 - Escores dos tipos de solo e manejo nos três primeiros componentes principais obtidos com os atributos físicos, químicos e biológicos do solo

\subsection{Qualidade da água}

Para efeito dos dados de qualidade de água analisados a seguir, vale ressaltar: a estação de monitoramento de qualidade de água de identificação E19A2 será também descrita como estação de nascente ou simplesmente nascente; a estação de coleta de água de identificação E19A será também descrita como estação de jusante ou simplesmente jusante.

\subsubsection{Variáveis físicas e químicas}

\subsubsection{Análise de tendência em função do tempo (1996 a 2002) para cada estação}

Primeiramente avaliou-se o comportamento dos dados ao longo do período de 1996 a 2002, visando identificar possíveis correlações com as atividades do ano agrícola. A estação de jusante tem como fonte de poluição, além da agricultura 
(poluição difusa), uma agroindústria (poluição pontual) situada entre a nascente e a jusante.

\subsubsection{Comparação dos dados das variáveis físicas e químicas das duas estações de coleta com os respectivos parâmetros estabelecidos pela resolução $n^{0}$ 20/86 do CONAMA, artigo $5^{\circ}$, que caracteriza as águas doces enquadradas na Classe 2.}

A legislação brasileira, por meio da Resolução $n^{\circ} 20$ do Conselho Nacional do Meio Ambiente (CONAMA), estabelece parâmetros de qualidade para águas doces, salinas e salobras do Território Nacional, classificando-as em nove classes segundo seus usos preponderantes. No caso das águas doces, as seguintes classificações são possíveis: Classe especial, Classe 1, Classe 2, Classe 3 e Classe 4.

As Figuras de 29 a 39 apresentam a comparação gráfica entre as variáveis Turbidez, Sólidos Totais Dissolvidos, Amônia, Nitrato, Nitrito, Fosfato Total, Oxigênio Dissolvido, Demanda Bioquímica de Oxigênio, Coliformes Fecais, Coliformes Totais e pH e os seus respectivos parâmetros estabelecidos pela resolução nº20 de 1986 do CONAMA. Essa comparação possibilita uma visão geral de como vem se comportando, de 1996 a 2002, as referidas variáveis de qualidade da água no trecho do rio Passo Cue contemplado nesse estudo.

Na Figura 29 pode-se observar que, para todo o período analisado, tanto na nascente quanto na jusante, os valores de turbidez apresentaram-se dentro do limite estabelecido pelo CONAMA para a Classe II, isto é, 100 UNT. No entanto, em ambos os locais do rio observa-se alguns picos de turbidez da água. A ocorrência de picos de turbidez simultaneamente em ambas as estações pode ser observada em fevereiro/98 e fevereiro/00 e fevereiro/01; embora com alta turbidez da água, neste último mês citado, a estação de jusante encontra-se com sua curva em declínio. Nesses três períodos explicitados a turbidez da água esteve relacionada com os altos índices pluviométricos, ou seja, 312mm, 300mm e 314mm, respectivamente. Analisando todo o período (1996 a 
2002) pode-se verificar que nos períodos de baixa precipitação predomina a situção de maior turbidez na estação de jusante. Isso é explicado pelo fato da qualidade da água desta estação refletir o efeito do uso da terra de toda a área de contribuição a microbacia; a qual engloba inclusive a área de contribuição da estação da nascente. Em concordância com esse aumento na turbidez da água, simultaneamente em ambos os locais monitorados, pode-se verificar também que em fevereiro/98 ocorreu um aumento na DBO e DQO de ambas as estações.

Em fevereiro/00, a elevação da turbidez na nascente e na jusante alcançou patamares semelhantes (em torno de $60 \mathrm{UNT}$ ), havendo também picos na população de Coliformes Fecais e na DQO. Apesar da elevação dos teores de Nitrogênio Total Kjeldahl, Nitrogênio Amoniacal e na quantidade de Resíduos Suspensos - e também do aumento da DQO -, observa -se uma redução na condutividade elétrica da água.

A queda no OD e foi mais intensa na jusante do que na nascente levando, portanto, a uma maior DBO na jusante. Isso levaria a inferir sobre uma maior elevação na carga orgânica (neste caso indicada pela presença de Coliformes Fecais) na água da estação jusante, tendo em vista a estreita relação entre essas variáveis (Oliveira, 1993). Entretanto, constatou-se o contrário, ou seja, a maior elevação da população de Coliformes Fecais ocorreu na nascente. Para explicar essa constatação pode-se observar que, comparativamente à nascente, na jusante houve uma maior elevação para as seguintes variáveis: DQO (Figura 43), STD (Figura 30), Resíduos Suspensos (Figura 31), Condutividade Elétrica (Figura 32), Nitrogênio Total Kjeldahl (Figura 33), $\mathrm{NH}_{3}$ (Figura 34) e Fosfato Total (Figura 37). Por outro lado, pode-se explicar essa diferença na DBO pelo processo de autodepuração do rio (Benassi, 2002).

Do exposto pode-se inferir, portanto, que a redução do Oxigênio Dissolvido (OD) na estação de jusante em Fevereiro/00 é explicada pelo aumento na concentração de resíduos suspensos na água. Entretanto, como ocorreu redução na condutividade elétrica na água, tais resíduos tem origem na presença de poluentes orgânicos ao invés de nutrientes oriundos das áreas agrícolas; isso porque o aumento na concentração de nutrientes na água levaria a uma elevação da condutividade elétrica, o contrário do observado (Lima \& Zakia, 1998). 
Em agosto/96 e em novembro/00 pode-se observar uma elevação da turbidez apenas na estação de jusante. Observa-se ainda uma elevação na população de Coliformes Fecais em novembro/00, em agosto/96 não estavam sendo monitoradas as vairáveis bacteriológicas.

Em agosto/96 essa mesma estação (jusante) apresentou aumentos nas quantidades de Resíduos Suspensos, Nitrogênio Total Kjeldahl, Amônia, Nitrito, Fosfato Total, Carbonato de Cálcio (alcalinidade), além de elevação da DBO e DQO, sendo a elevação destas duas últimas variáveis uma conseqüência da redução do Oxigênio Dissolvido (Figuras 31, 33, 34, 36, 37, 38, 39, 40 e 41). Nesse mesmo mês em questão, para a variável Resíduos Suspensos na água, verifica-se um valor de $19 \mathrm{mg}$. L $\mathrm{L}^{-1}$ na estação de jusante contra $4 \mathrm{mg} . \mathrm{L}^{-1}$ na nascente. Já a estação da nascente apresentou alteração visível graficamente apenas quanto à elevação da variável alcalinidade total que mede o teor de carbonato de cálcio presente na água. Pela observação da Figura 37, verifica-se que houve elevação do teor de fosfato apenas na estação de jusante e ainda que esta elevação se deu apesar do baixo índice pluviométrico. Devido à inexistência do monitoramento bacteriológico nesta época, não se pode afirmar se esse comportamento das variáveis é reflexo de poluição por fonte pontual, com lançamento situado entre as duas estações. Entretanto a diferença na alteração da qualidade da água desses dois locais do rio é um indicativo desse tipo de poluição.

Em novembro/00, embora a elevação da turbidez tenha ocorrido apenas na estação de jusante (valor igual a 90 NTU), em ambas as estações ocorreram elevações no valor da condutividade elétrica e na quantidade de Fosfato Total e de Coliformes Totais. Entretanto, é importante observar que apenas para a estação de jusante se verifica elevação na quantidade de Coliformes Fecais presentes na água e redução no Oxigênio Dissolvido, podendo-se dessa forma inferir que a turbidez nesse caso está relacionada com a presença de dejetos orgânicos na água.

Em fevereiro/01 ocorreu aumento na turbidez, no teor de Nitrogênio Total Kjeldahl e na população de Coliformes Totais em ambas as estações, indicando, portanto, ser a turbidez neste caso causada pela presença de carga orgânica no curso d’água. 


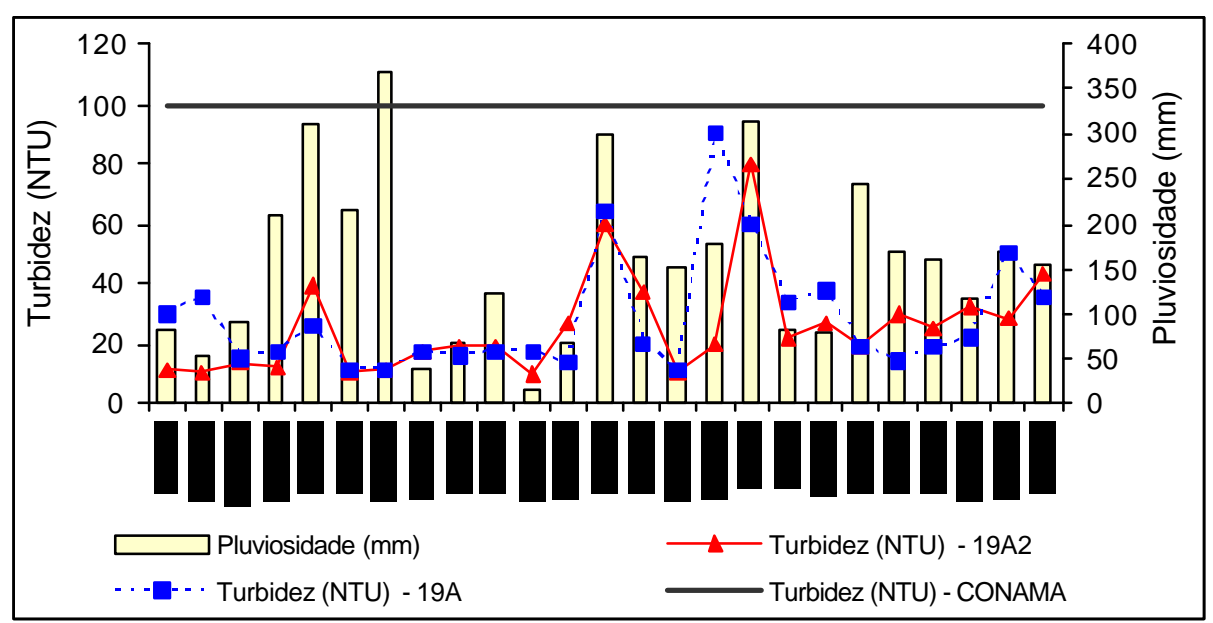

Figura 29 - Turbidez da água nas duas estações de coleta e o respectivo parâmetro estabelecido pelo CONAMA

Pela observação da Figura 30, verifica-se que ao longo de todo o período estudado a variável STD manteve-se dentro dos limites estabelecidos pela legislação. É importante ressaltar que as análises laboratoriais para a variável STD se deram de fevereiro/1996 a agosto/2000, enquanto que de novembro/2000 em diante dispõem-se apenas dos resultados das análises de Resíduos Suspensos.

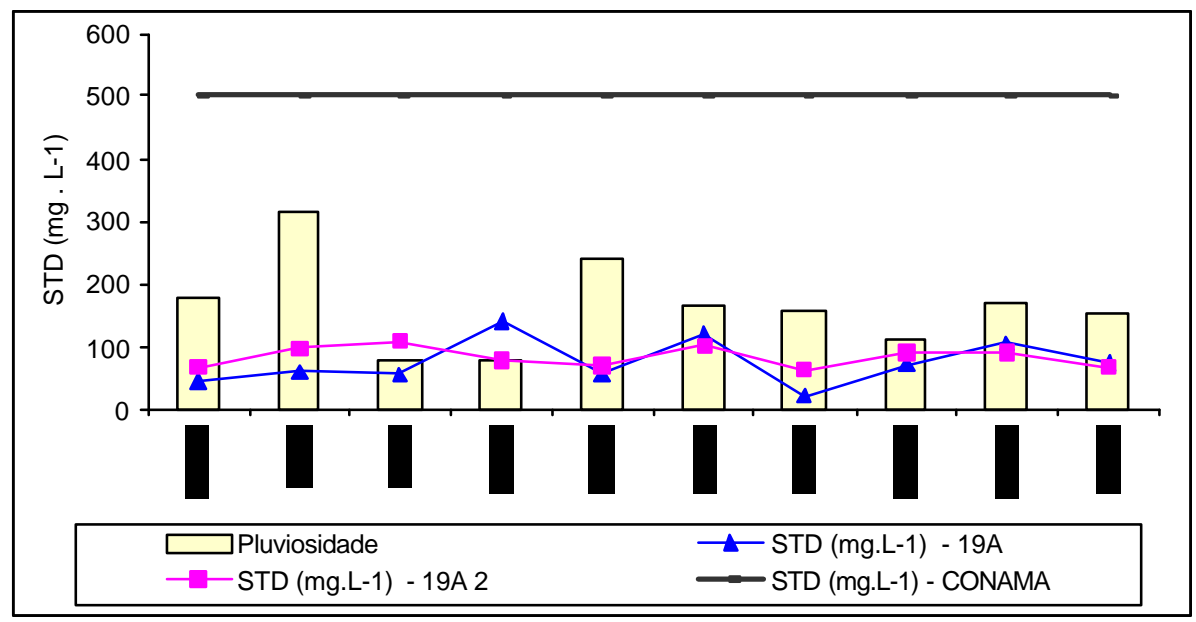

Figura 30 - Sólidos Totais Dissolvidos na água nas duas estações de coleta e o respectivo parâmetro estabelecido pelo CONAMA 


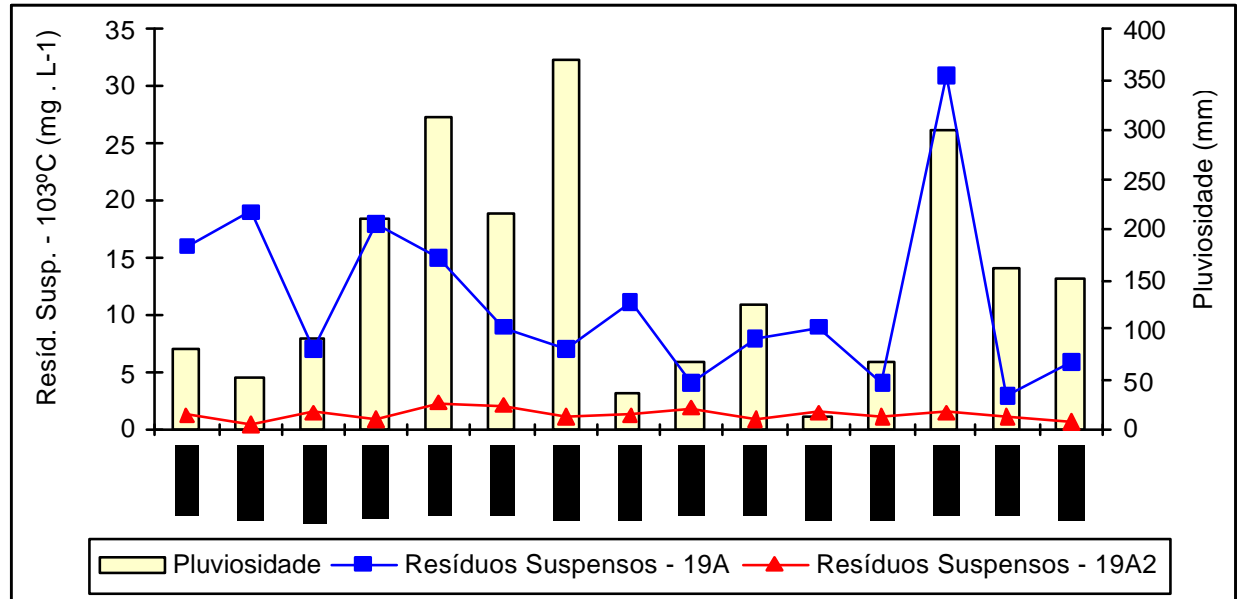

Figura 31 - Resíduos Suspensos na água nas duas estações de coleta

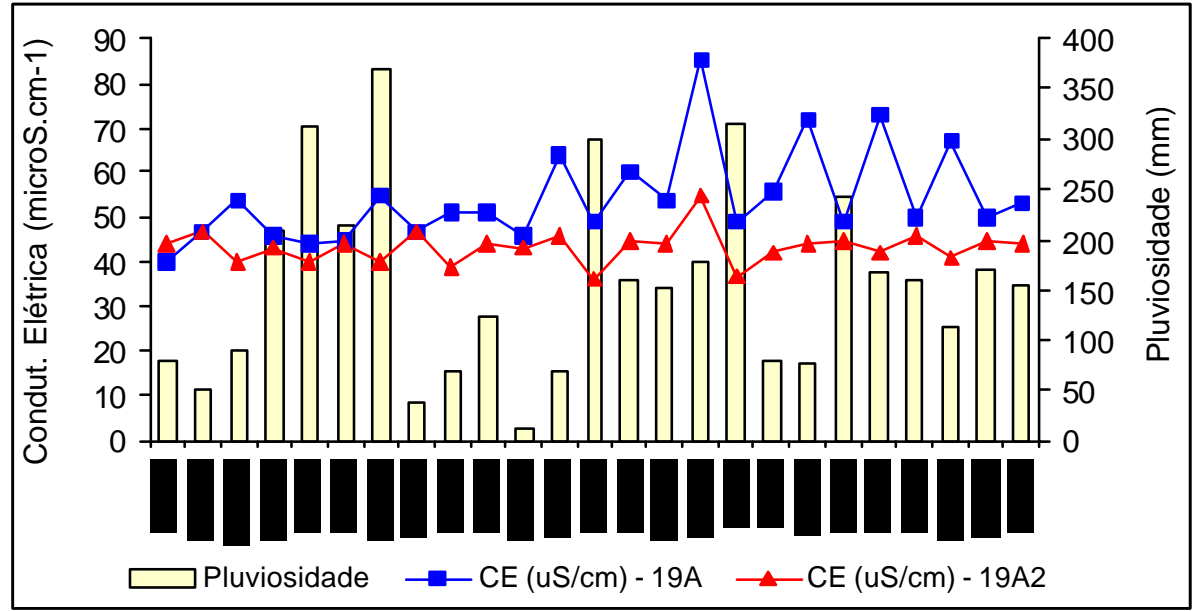

Figura 32 - Condutividade Elétrica da água nas duas estações de coleta 


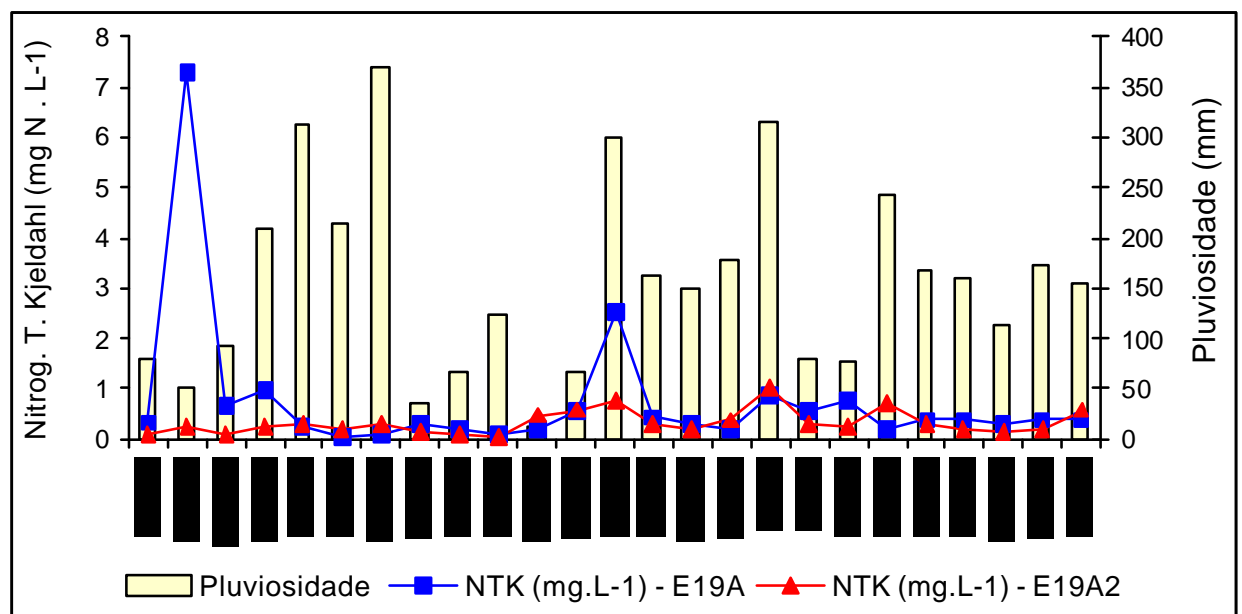

Figura 33 - Nitrogênio Total Kjeldahl na água na água nas duas estações de coleta

Na Figura 34 verifica-se que em praticamente todo o período considerado, em ambas as estações, os valores de Amônia na água ultrapassaram o limite de 0,02 mg . $\mathrm{L}^{-1}$ estabelecido pelo CONAMA. Para a estação da nascente com exceção de maio/1998, cujo valor foi igual a $0,01 \mathrm{mg} . \mathrm{L}^{-1}$ e em fevereiro/1996, novembro/1998, novembro/2001 e agosto/2002, cujos valores encontrados foram iguais a $0,02 \mathrm{mg} \cdot \mathrm{L}^{-1}$, no restante dos meses analisados a água esteve com os teores de amônia acima do permitido.

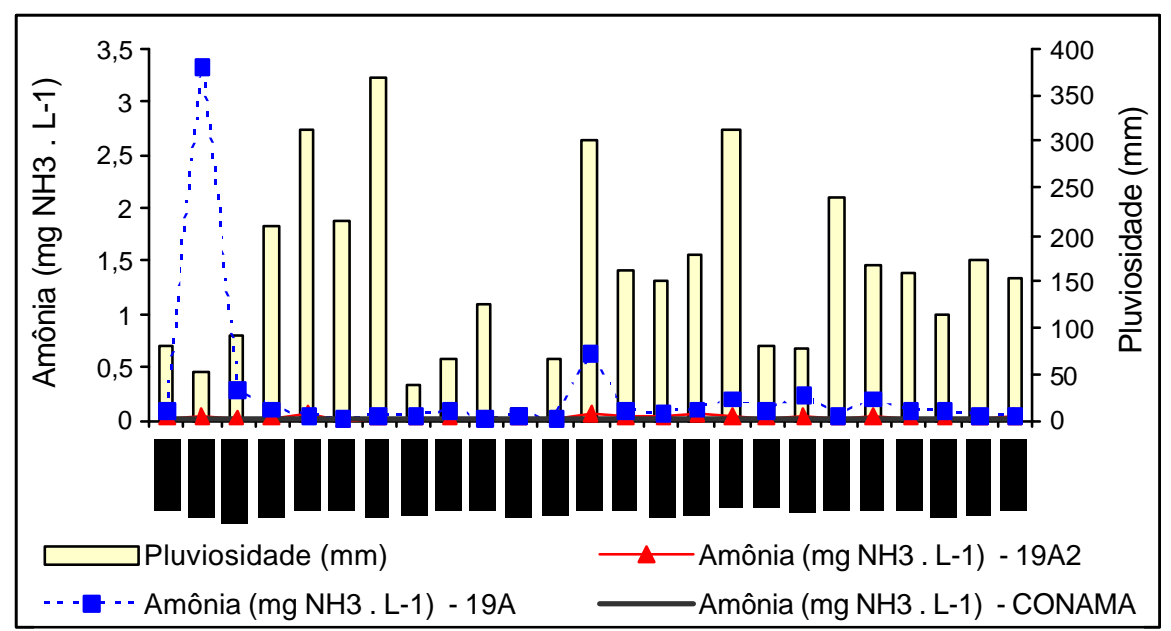

Figura 34 - Nitrogênio Amoniacal na água na água nas duas estações de coleta 
No caso do Nitrato, conforme mostra a Figura 35, os seus teores se mantiveram dentro do permitido, $10 \mathrm{mg} . \mathrm{L}^{-1}$, ao longo de todo o período, sendo que o maior valor encontrado foi $1,3 \mathrm{mg}$. $\mathrm{L}^{-1}$ em maio/1998 na estação da nascente.

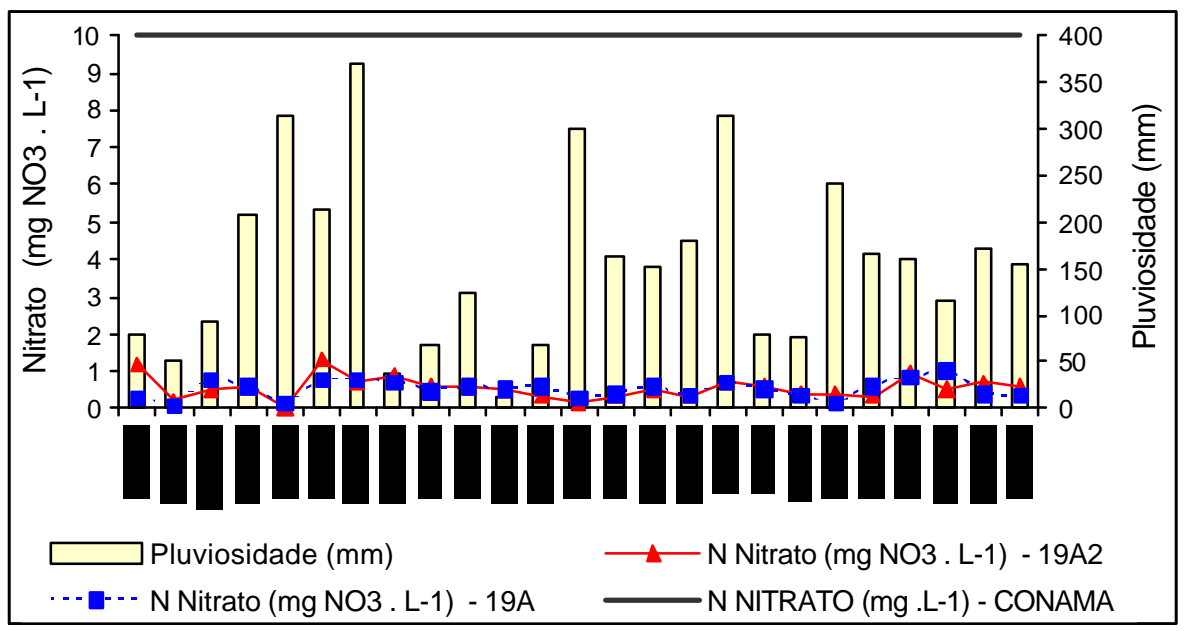

Figura 35 - Nitrato na água nas duas estações de coleta

Semelhantemente ao Nitrato, os teores de Nitrito na água, em ambas as estações, também se mantiveram bem abaixo do limite máximo permitido, isto é, 1,0 mg. $\mathrm{L}^{-1}$.

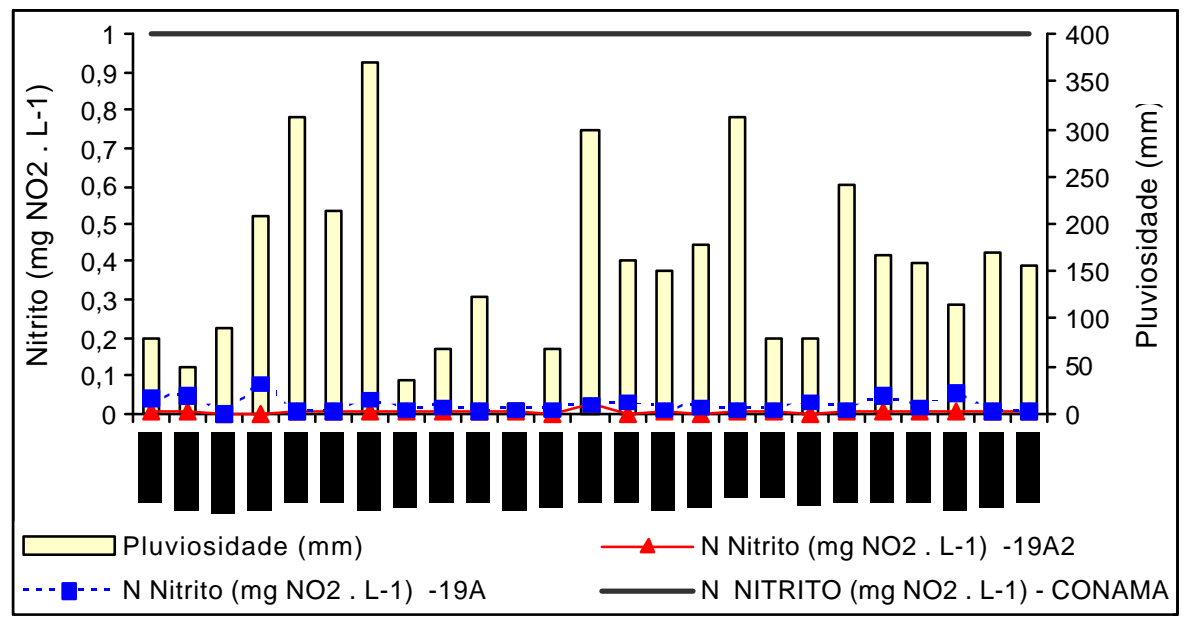

Figura 36 - Nitrito na água nas duas estações de coleta 
Quanto aos teores de fosfato (Figura 37), predominaram os níveis elevados, superiores ao permitido, ou seja, 0,025 $\mathrm{mg} . \mathrm{L}^{-1}$, ao longo de todo o período de análise. Em agosto/1996 houve uma drástica elevação na jusante. Este mesmo pico, também foi observado com a concentração de Nitrogênio Total Kjeldahl, com a alcalinidade da água, com a DBO e com a DQO. Entretanto, a elevação da turbidez não teve a mesma proporção. Apesar de não se dispor dos dados de Coliformes Fecais para esta época, fica evidente que esta alteração na qualidade da água é oriunda da presença de carga orgânica, tendo em vista que quando o Nitrogênio está presente na água na forma orgânica é indicativo de poluição por compostos orgânicos. Confirmando esse indicador tem-se a elevação da DBO da água, como reflexo do consumo de oxigênio no processo de decomposição dos poluentes orgânicos.

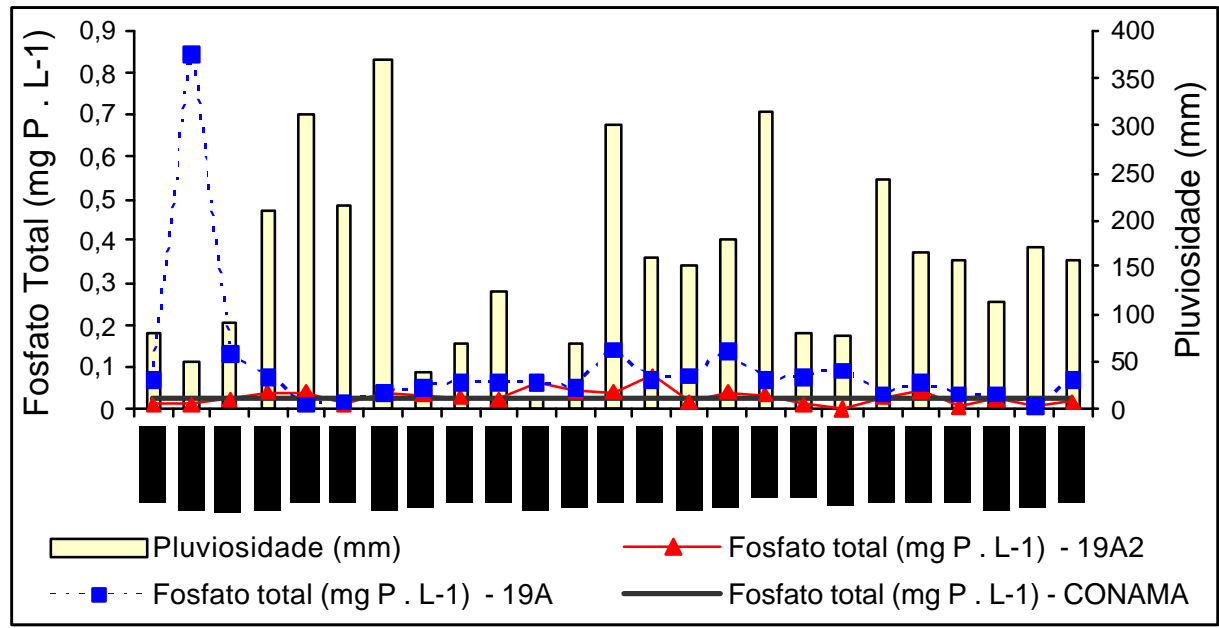

Figura 37 - Fosfato Total na água mas duas estações de coleta 


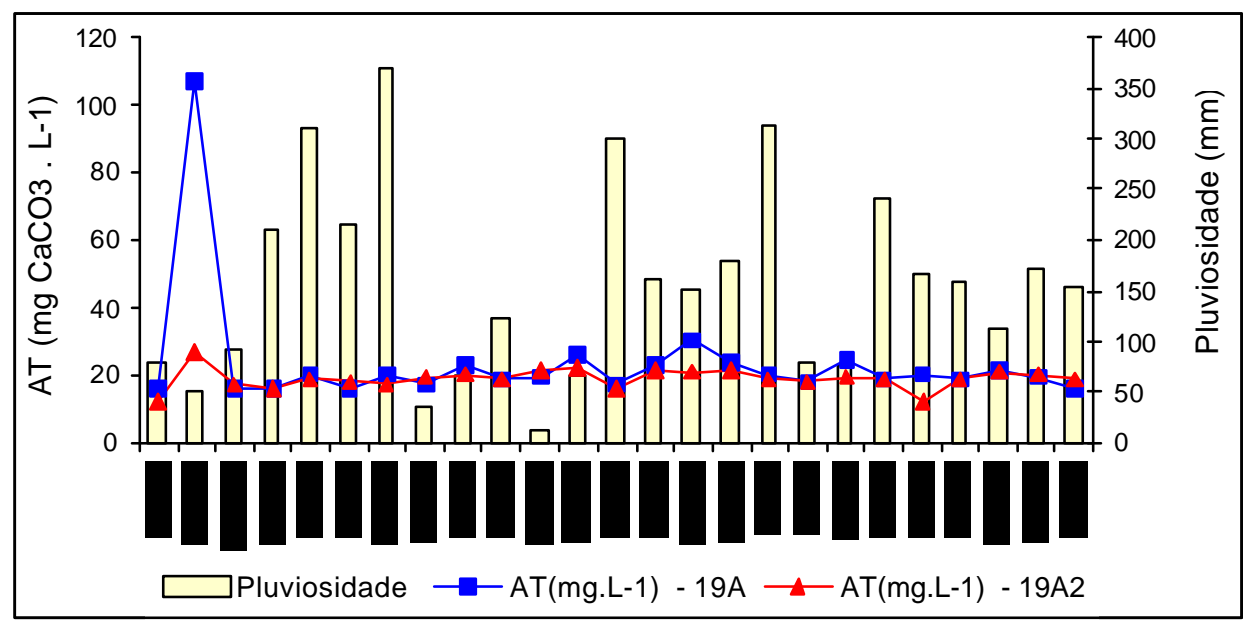

Figura 38 - Alcalinidade Total na água das duas estações de coleta

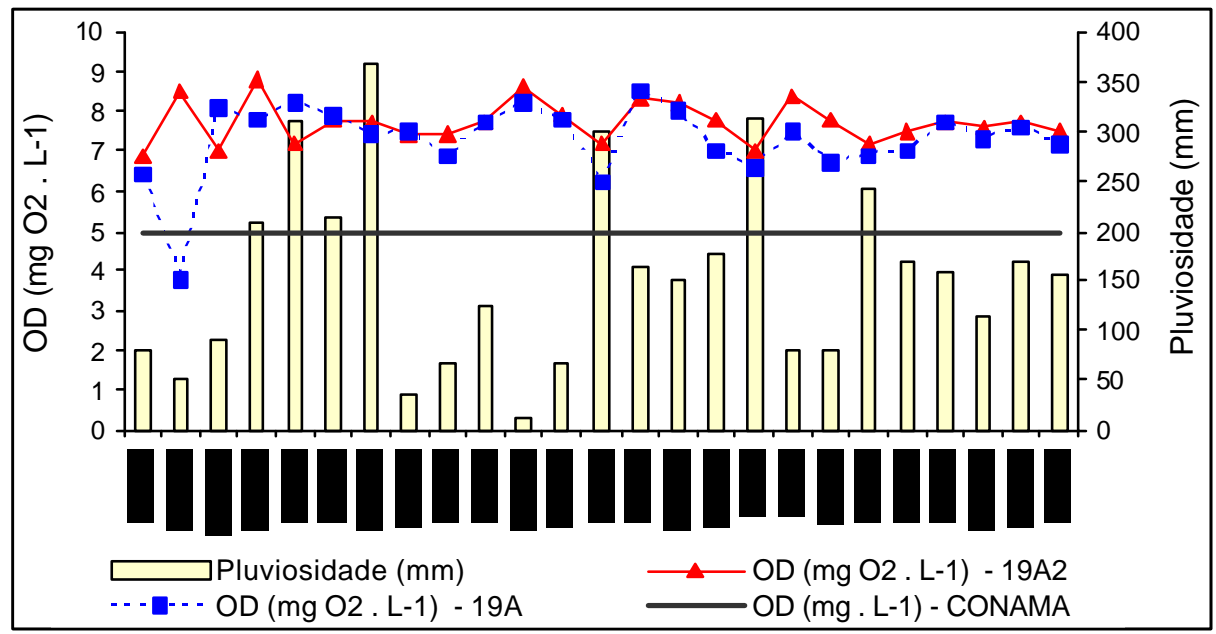

Figura 39 - Oxigênio Dissolvido na água das duas estações de coleta

Na Figura 40 pode-se observar que em ago/1999 na estação da nascente houve um pico de DBO; entretanto neste mesmo mês ocorreu um aumento na concentração de OD, podendo ser neste caso um erro de medição de uma das duas variáveis. 


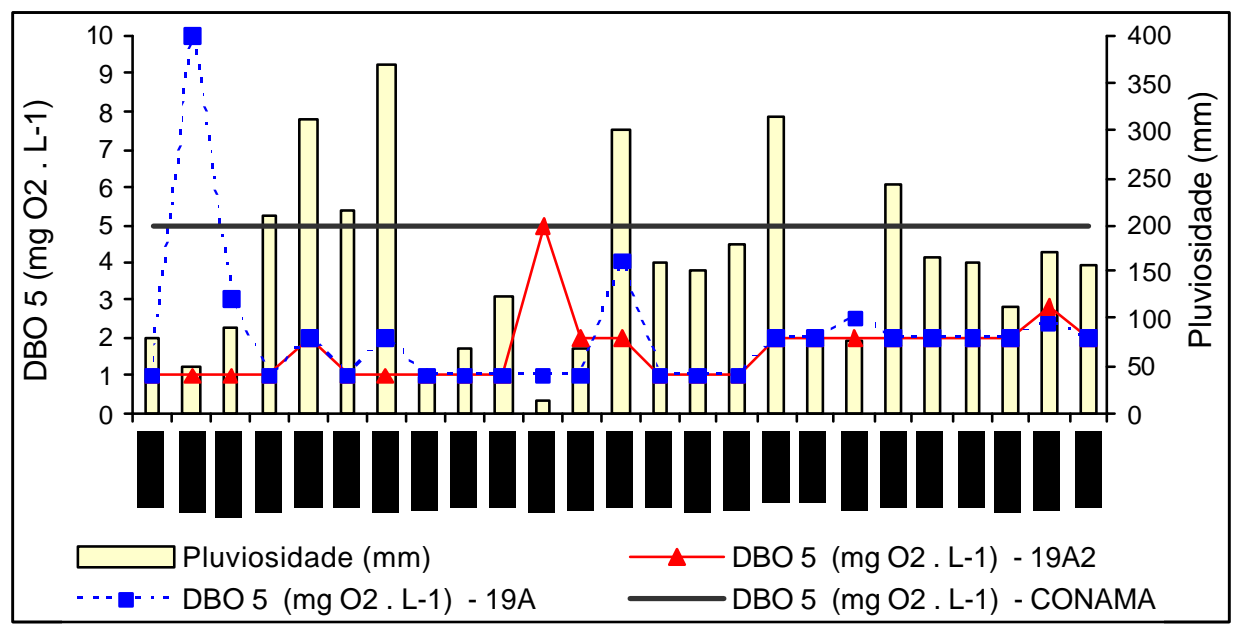

Figura 40 - Demanda Bioquímica de Oxigênio na água das duas estações de coleta

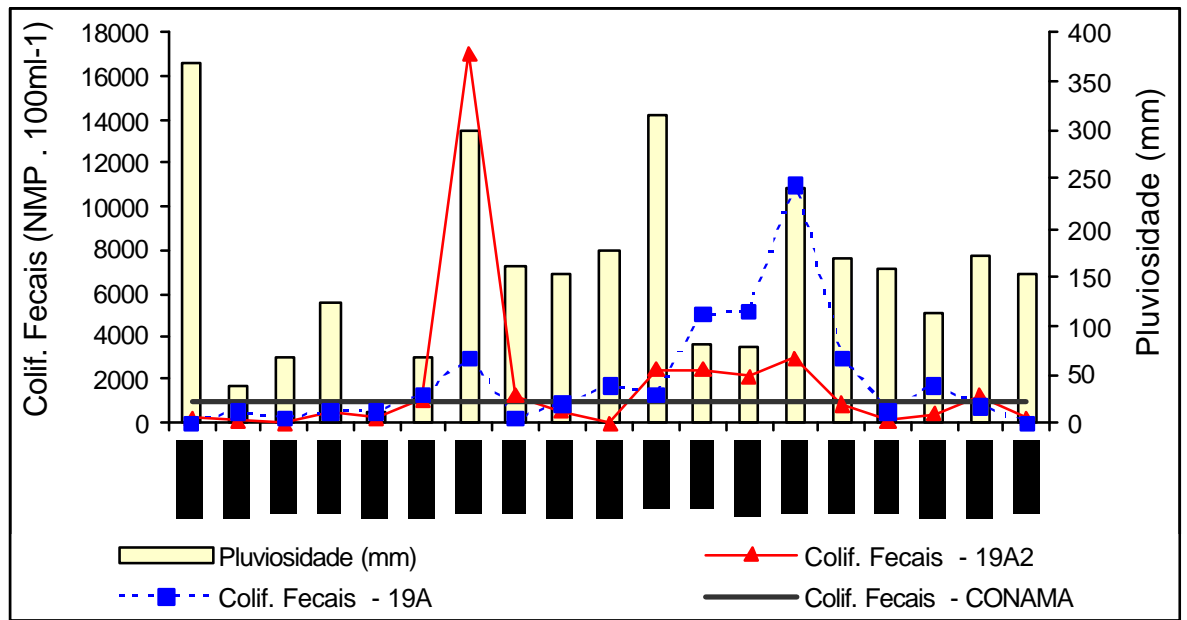

Figura 41 - Coliformes Fecais na água das duas estações de coleta 


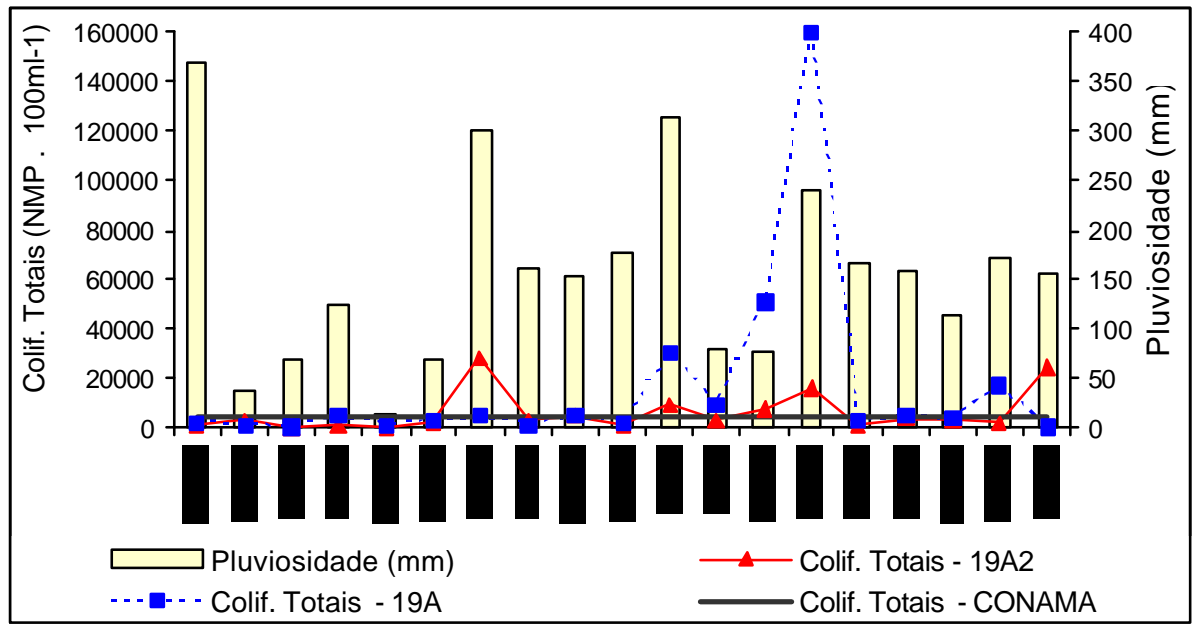

Figura 42 - Coliformes Fecais na água das duas estações de coleta

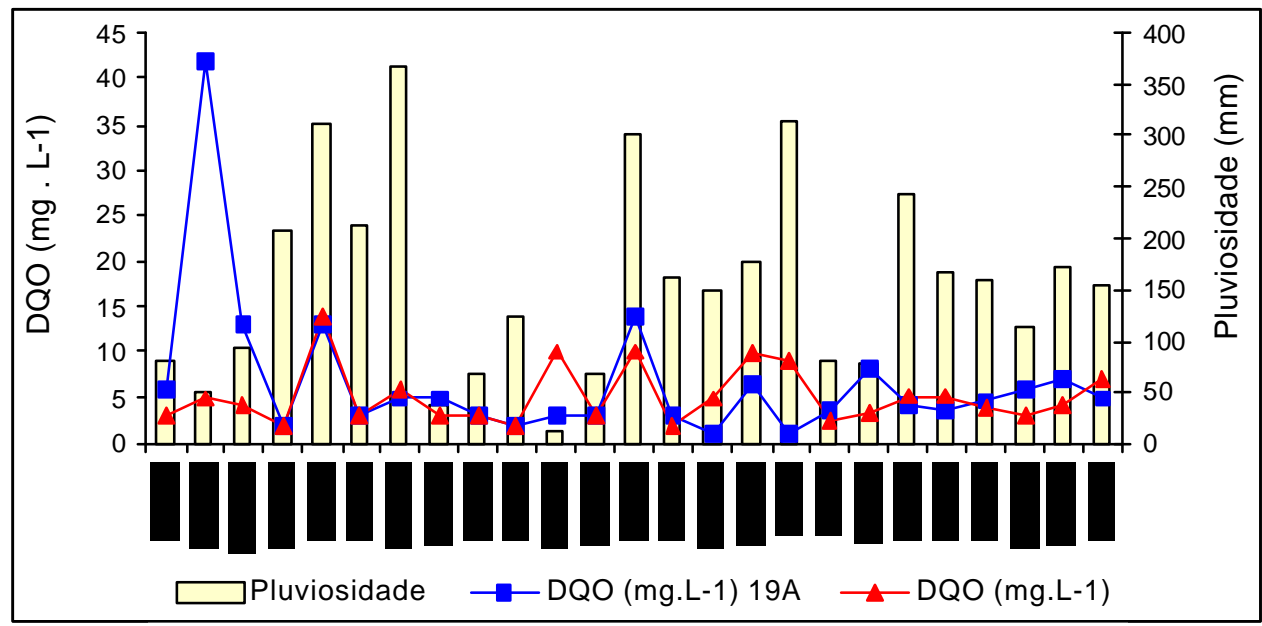

Figura 43 - Demanda Química de Oxigênio na água das duas estações de coleta 


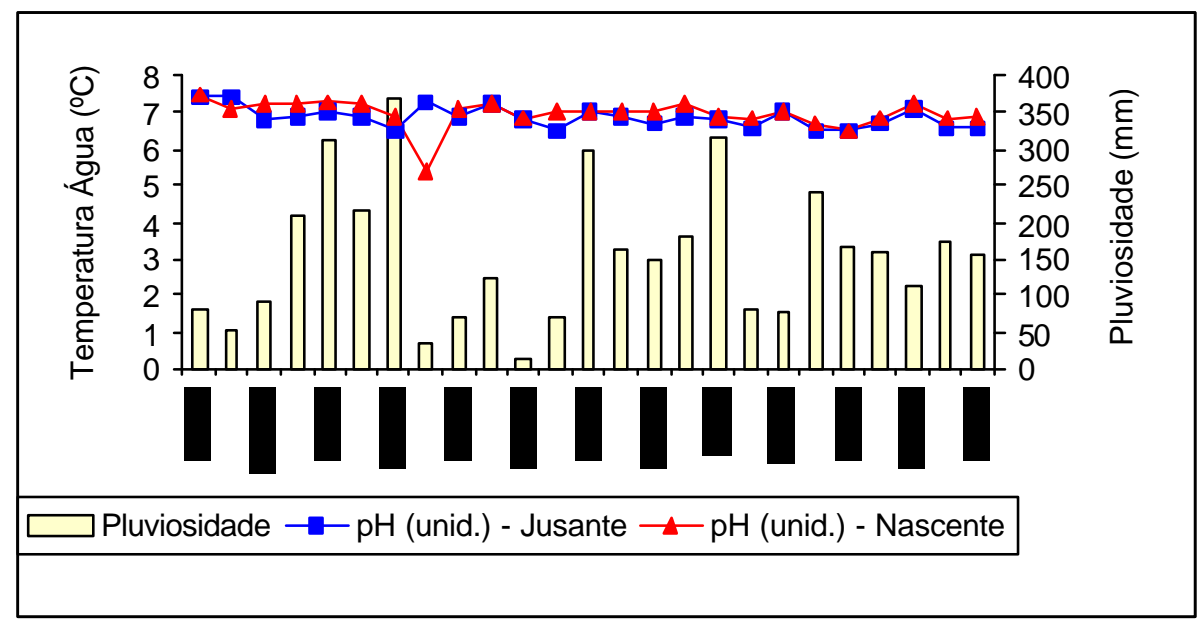

Figura 44 - Temperatura da água das duas estações de coleta

Na Tabela 26 pode-se verificar os baixos valores do coeficiente de regressão encontrado entre os dados das variáveis Nitrogênio Total Kjeldahl, Amônia, Nitrito, Nitrato, Fosfato Total, Turbidez, Sólidos Totais Dissolvidos, Condutividade Elétrica e Coliformes Fecais com os dados pluviométricos. Conforme exposto acima, isso confirma a inadequação do método de amostragem de água para a avaliação da poluição difusa e pontual.

\subsubsection{Comparação do comportamento das variáveis, físicas, químicas e microbiológicas entre as duas estações de coleta (cabeceira e jusante)}

Devido às diferenças na condição da mata ciliar e na cobertura do solo na área de contribuição das duas estações de coleta de água, a comparação dos dados de ambas, visa identificar possíveis correlações entre esses aspectos com a qualidade da água.

$\mathrm{Na}$ Figura 45 pode-se verificar que com exceção do nitrato, todas as demais formas de nitrogênio, além do Fosfato Total, ocorreram em maiores concentrações na jusante da microbacia. Entretanto, o alto coeficiente de variação dos dados (representado no gráfico) para as variáveis NTK e $\mathrm{N}$ amoniacal dificultam as interpretações dos resultados. 


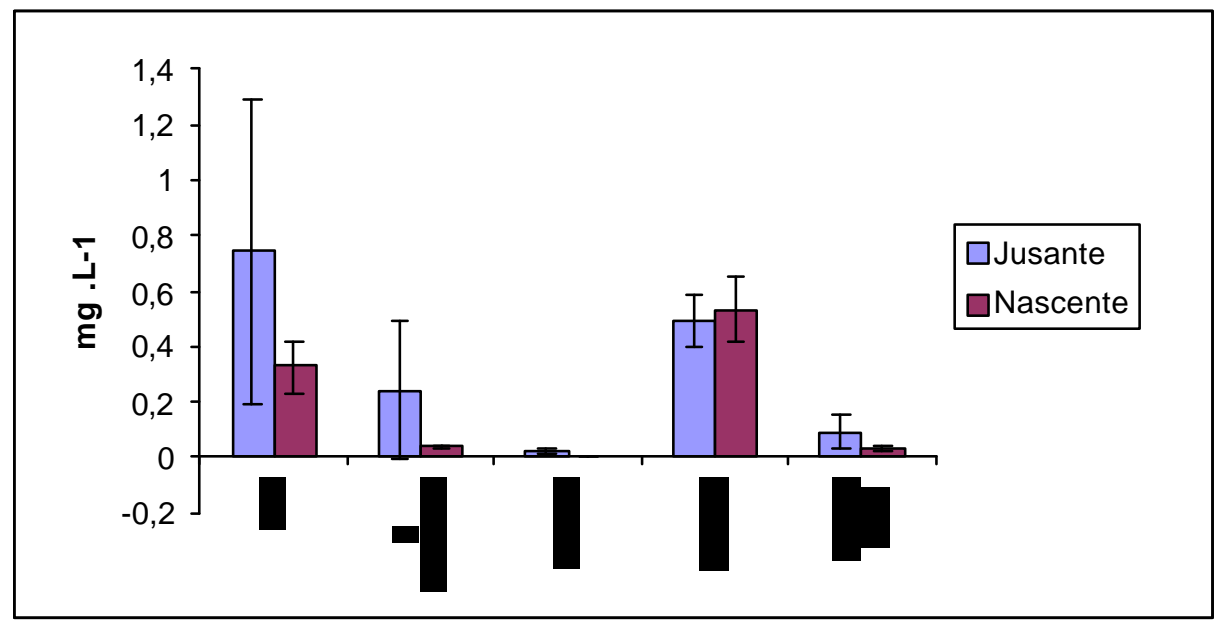

Figura 45 - Média do período de 1996 a 2002 para as diferentes formas de Nitrogênio e de Fosfato Total

A avaliação da qualidade da água com base na média de $\mathrm{OD}, \mathrm{DBO}_{5}, \mathrm{DQO}$ e coliformes, indica a perda de qualidade na jusante em relação à nascente, conforme mostram a Figura 46, entretanto, dentro das limitações impostas pelo intervalo de confiança da média.

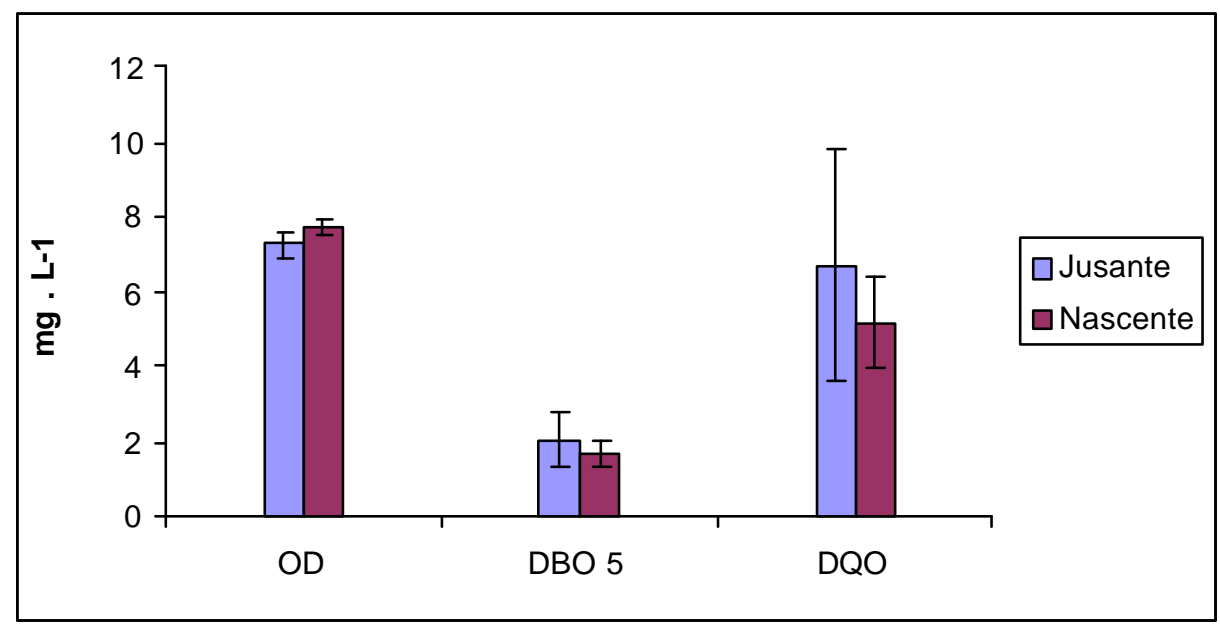

Figura 46 - Média do período de 1996 a 2002 para as variáveis físicas Oxigênio

Dissolvido, Demanda Bioquímica de Oxigênio e Demanda Química de Oxigênio 


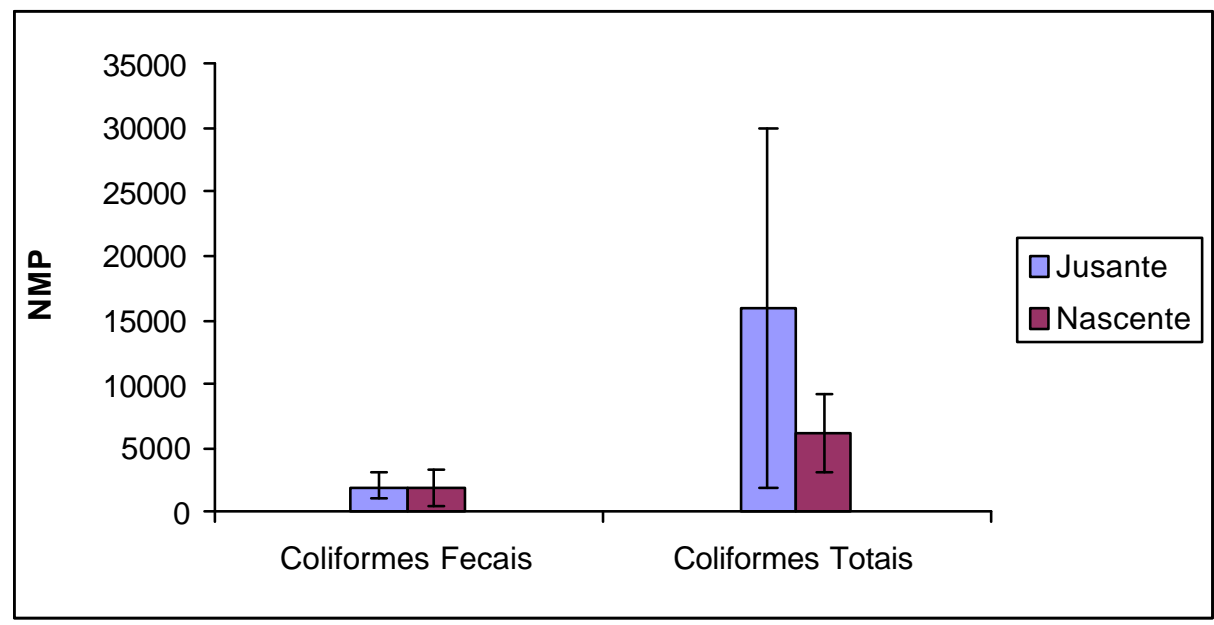

Figura 47 - Média do período de 1996 a 2002 para as variáveis bacteriológicas

Coliformes Fecais e Coliformes Totais

Como é sabido e largamente difundido na literatura, a qualidade da água é o reflexo do uso da terra na microbacia, sendo que a qualidade tende a piorar das nascentes para a jusante. Essa tendência foi verificada na microbacia em estudo, o que pode ser visto nas Figuras 45, 46 e 47, nas quais a concentração média de nutrientes na água e a média de OD, DBO e DQO no período foram maiores jusante do que na nascente da microbacia. A quantidade média de Coliformes Fecais no período foi semelhante para ambos os locais de monitoramento,enquanto que a presença de Coliformes Totais foi em média superior para a jusante. Porém deve ser observado que o intervalo de confiança da média dos valores obtidos pelo monitoramento da jusante foi alto, indicando a baixa precisão dos resultados.

A Tabela 25 apresenta os valores do coeficiente de regressão encontrados por ocasião desta análise realizada com pares de variáveis especificados. A partir do conceito da análise de regressão, pode-se concluir que, com exceção do par de variáveis "Turbidez x Resíduos Suspensos" na água (jusante), todas os demais pares de variáveis analisados apresentam baixo grau de dependência mútua, ou seja, o comportamento de uma variável não explica o comportamento da outra. 
Tabela 25. Análise de regressão entre variáveis para uma mesma estação de coleta

\begin{tabular}{lcc}
\hline \multicolumn{1}{c}{ Pares de Variáveis } & Jusante & $\mathbf{r}^{\mathbf{2}}$ \\
\hline pH x AT & 0,07 & Nascente \\
pH x CE & 0,08 & - \\
pH x NK & 0,16 & 0,016 \\
PH x NH3 & 0,18 & - \\
pH x NO2 & 0,07 & 0,04 \\
pH x NO3 & 0,03 & - \\
pH x PO4 & 0,17 & - \\
NK x NTU & 0,05 & - \\
NK x CT & - & 0,48 \\
NK x CF & 0,02 & 0,35 \\
CE x Resíd. Susp. & 0,31 & 0,22 \\
Turbidez x Resíd. Susp. & $\mathbf{0 , 7 6}$ & 0,24 \\
Fosfato x Resíd. Susp. & 0,125 & 0,10 \\
Alcalinidade T. x Resíd. Susp. & 0,04 & - \\
STD x CE & 0,18 & 0,09 \\
CE x NTU & & 0,41 \\
STD x NTU & 0,04 & \\
STD x PT & 0,024 & 0,07 \\
AT x STD & 0,13 & 0,06 \\
AT x PT & 0,04 & 0,22 \\
PO4 x NTU & 0,04 & 0,08 \\
PO4 x NTK & 0,93 & 0,05 \\
PO4 x NO3 & 0,16 & 0,08 \\
\hline
\end{tabular}

Buscourse explicar o comportamento de algumas das variáveis monitoradas com base no regime de chuvas da região, mas como não se dispunha de monitoramento pluviométrico na microbacia utilizourse os dados da estação pluviométrica mais próxima, isto é, a estação de Hernandarias - PY. Dessa forma não foi possível explicar o comportamento dessas variáveis, sabidamente dependentes da precipitação, com base nos dados pluviométricos disponíveis. 
Tabela 26. Análise de regressão entre variáveis físicas e químicas e a pluviosidade

\begin{tabular}{|c|c|c|}
\hline $\begin{array}{c}\text { Variáveis Físicas e } \\
\text { Químicas x Pluviosidade }\end{array}$ & Jusante & Nascente \\
\hline NK x Pluviosidade & - & 0,2 \\
\hline NH3 x Pluviosidade & - & 0,13 \\
\hline NO2 x Pluviosidade & - & 0,12 \\
\hline NO3 x Pluviosidade & - & - \\
\hline PO4 x Pluviosidade & - & - \\
\hline Turbidez x Pluviosidade & - & 0,2 \\
\hline STD x Pluviosidade & 0,11 & - \\
\hline CE x Pluviosidade & - & 0,14 \\
\hline CF x Pluviosidade & - & - \\
\hline CT x Pluviosidade & - & - \\
\hline
\end{tabular}

\subsection{2 Índice BMWP' (Biological Monitoring Working Party System)}

A inserção dos macroinvertebrados bentônicos como bioindicadores para o presente estudo restringiu-se à aplicação do índice BMWP', o qual vem sendo obtido e usado pelo IAP no Programa de Monitoramento de Qualidade da Água dos Afluentes da Margem Esquerda do Reservatório de ITAIPU. É, portanto, uma informação que, aliada àquelas fornecidas pelas variáveis físicas e químicas auxilia a avaliação do efeito do uso e manejo do solo na microbacia sobre a qualidade da água do deflúvio.

Segundo (Loyola, 2000) um procedimento envolvendo macroinvertebrados identificados ao nível taxonômico de família (alguns casos, ordem), utilizando apenas a presença ou ausência destes nas amostras, foi desenvolvido para ser usado no "1980 River Water Quality Survey in Great Britain”. Este índice foi chamado Biological Monitoring Working Party System (BMWP).

De acordo com (Loyola, 2000), este índice ordena as famílias dos macroinvertebrados bentônicos em nove grupos, sendo que as famílias pertencentes ao mesmo grupo atribui-se o mesmo grau de tolerância à poluição. Este gradiente de tolerância à poluição varia de 1 a 10, sendo os maiores valores atribuídos aos grupos de famílias menos tolerantes e os menores valores atribuídos aos grupos de famílias mais tolerantes à poluição; famílias mais tolerantes são, logicamente, menos sensíveis e, 
portanto, menos eficientes como indicadoras de um determinado distúrbio, daí o motivo de atribuir-se a esses grupos os menores valores e vice-versa.

O índice BMWP utiliza os macroinvertebrados aquáticos, mas pode ser usado perfeitamente com os macroinvertebrados bentônicos.

Este índice "BMWP" foi adaptado por Alba-Tercedor \& Jimenéz-Millán (1987) citados por Loyola (2000), os quais incluíram à lista original novas famílias da fauna zoobentônica de ocorrência ra Península Ibérica, onde esses autores aplicaram o índice. Com essa adaptação o índice passou a ser denominado BMWP'.

Com relação à região Oeste do Paraná, mais especificamente na Bacia Hidrográfica Paraná III, da qual faz parte a microbacia do rio Passo Cue, a aplicação deste índice está respaldada na série histórica de 10 anos de dados do projeto "Monitoramento da qualidade da água de afluentes da margem esquerda do Reservatório de Itaipu" o qual, além dos macroinvertebrados bentônicos, contempla também as variáveis, físicas, químicas e microbiológicas. A partir desse projeto vem sendo feita a caracterização dos ambientes lóticos e lênticos quanto a ocorrência de macroinvertebrados bentônicos. Com essa caracterização, à tabela de grupos de famílias de Alba-Tercedor \& Jimenéz-Millán (1987) citados por Loyola (2000) foram adicionados 13 novas famílias de ocorrência regional, adotando-se para isso os seguintes critérios: equivalência ecológica e semelhança quanto ao nível de tolerância à poluição. O estudo teve como resultado a adaptação do índice BMWP' para os rios da bacia Hidrográfica Paraná III, os quais drenam para o reservatório de Itaipu. O índice BMWP', juntamente com o monitoramento das variáveis físicas, químicas e microbiológicas, vem sendo usado desde de 1998 para classificar a qualidade da água de 22 estações de amostragem distribuídas nos afluentes da margem esquerda do reservatório de Itaipu (Loyola, 2000).

A Tabela 28 apresenta a listagem do Índice BMWP' após as adaptações de Loyola (2000), contendo também as respectivas pontuações de cada grupo de famílias no que tange à tolerância das mesmas à poluição do ambiente aquático. As seguintes observações são válidas para essa tabela (Loyola, 2000): 
- Grupos em itálico: pontuação modificada por de Alba-Tercedor \& JimenézMillán (1987) citados por Loyola (2000);

- Grupos em negrito: adicionados por Alba-Tercedor \& Jimenéz-Millán (1987) citados por Loyola (2000);

- Grupos sublinhados: adicionados por Loyola (2000).

Segundo IAP e Loyola (2000) a partir deste pode-se obter uma avaliação da qualidade da água conforme apresentado na Tabela 27.

Tabela 27. Correlação do índice BMWP' com as cinco classes de qualidade da água

\begin{tabular}{cccc}
\hline CLASSE & QUALIDADE & VALOR & SIGNIFICADO \\
\hline I & Boa & $>120$ & Águas muito limpas; \\
& & $101-120$ & Águas não contaminadas ou não alteradas de \\
modo sensível; \\
II & Aceitável & $61-100$ & São evidentes alguns efeitos de contaminação \\
III & Duvidosa & $36-60$ & Águas contaminadas \\
IV & Crítica & $16-35$ & Águas muito contaminadas \\
V & Muito Crítica & $<15$ & Águas fortemente contaminadas \\
\hline
\end{tabular}

Para se utilizar esse procedimento de correlação proposto por Alba-Tercedor \& Sánchez-Ortega (1988) citados por Loyola (2000), é preciso agrupar as famílias identificadas (no trecho do curso d'água em questão), segundo os nove grupos indicados também pelos mesmos autores. Feito isso, soma-se a pontuação obtida por essas famílias e com esse valor encontra-se a classe correspondente na tabela acima. 
Tabela 28. Agrupamento das famílias de macroinvertebrados bentônicos de acordo com a tolerância àpoluição (Loyola, 2000)

\section{FAMÍLIAS}

Pontuação

Siphlonuridae, Heptageniidae, Leptophlebiidae, Potamanthidae, Ephemeridae, Taeniopterygidae, Leuctridae, Capniidae, Perlodidae, Perlidae, Chloroperlidae, Aphelocheiridae, Phryganeidae, Molannidae, Beraeidae, Odontoceridae,

Leptoceridae, Goeridae, Lepidostomatidae, Brachycentridae, Sericostomatidae,

Athericidae, Blephariceridae

Astacidae, Lestidae, Calopterygidae, Gomphidae, Cordulegastridae, Aeshnidae, Corduliidae, Libellulidae, Psychomyiidae, Philopotamidae, Glossosomatidae

Ephemerellidae, Prosopistomatidae, Nemouridae, Gripopterygidae,

Rhyacophilidae, Polycentropodidae, Limnephelidae, Ecnomidae, Hydrobiosidae,

Pyralidae, Psephenidae

Neritidae, Viviparidae, Ancylidae, Thiaridae, Hydroptilidae, Unionidae,

Mycetopodidae, Hyriidae, Corophilidae, Gammaridae, Hyalellidae, Atyidae,

Palaemonidae, Trichodactylidae, Platycnemididae, Coenagrionidae,

Leptohyphidae

Oligoneuridae, Polymitarcyidae, Dryopidae, Elmidae (Elminthidae),

Helophoridae, Hydrochidae, Hydraenidae, Clambidae, Hydropsychidae,

Tipulidae, Simuliidae, Planariidae, Dendrocoelidae, Dugesiidae, Aeglidae

Baetidae, Caenidae, Haliplidae,Curculionidae, Chrysomelidae

Tabanidae, Stratyiomudae, Empididae, Dolichopodidae, Dixidae,

Ceratopogonidae, Anthomyidae, Limoniidae, Psychodidae, Sciomyzidae,

Rhagionidae

Sialidae, Corydalidae, Piscicolidae, Hydracarina

Mesoveliidae, Hydrometridae, Gerridae, Nepidae, Naucoridae, Limnocoridae,

Pleidae, Notonectidae, Corixidae, Veliidae, Helodidae,

Hydrophilidae, Hygrobiidae, Dytiscidae, Gyrinidae

Valvatidae, Hydrobiidae, Lymnaeidae, Physidae, Planorbidae, Bithyniidae,

Bythinellidae, Sphaeridae, Glossiphonidae, Hirudidae, Erpobdellidae, Asellidae,

\section{Ostracoda}

Chironomidae, Culicidae, Ephydridae, Thaumaleidae 
Tabela 29. Análise de regressão entre as variáveis físicas e químicas e os dados referentes aos macroinvertebrados bentônicos

\begin{tabular}{l|cc}
\hline $\begin{array}{l}\text { BMWP' x Variável Física ou } \\
\text { química }\end{array}$ & Jusante & $\mathbf{r}^{\mathbf{2}}$ \\
\hline BMWP' x NTU & - & Nascente \\
BMWP' x OD & 0,33 & - \\
BMWP' x SOD & 0,25 & 0,07 \\
BMWP' x DBO & 0,3 & 0,06 \\
BMWP' x DQO & 0,33 & 0,02 \\
BMWP' x NK & 0,26 & 0,09 \\
BMWP' x PO4 & 0,32 & - \\
BMWP' x AT & 0,28 & 0,34 \\
BMWP' x pH & 0,26 & - \\
BMWP' x STD & - & 0,55 \\
BMWP' x Resíd. Susp. & 0,08 & 0,13 \\
BMWP' x CE & 0,13 & 0,04 \\
BMWP' x CF & 0,094 & - \\
BMWP' x CT & 0,05 & - \\
BMWP' x NH3 & 0,34 & 0,075 \\
BMWP' x NO2 & 0,09 & - \\
BMWP' x NO3 & 0,012 & 0,25 \\
BMWP' x PLUV. & - & 0,21 \\
No $^{\circ}$ otal Taxa OD & 0,28 & - \\
\hline
\end{tabular}

Conforme pode ser observado na Tabela 29, foi encontrado baixos coeficientes de regressão para todos pares de variáveis considerados, indicando que, com a série histórica disponível, analisada por este procedimento estatístico, não se explica o comportamento dos macroinvertebrados bentônicos em função das variáveis físicas e químicas, ou vice-versa. De acordo com Loyola (2000), a diferença entre a classificação física e química com a classificação com base nos macroinvertebrados bentônicos se explica pela diferença da sensibilidade desses indicadores a um distúrbio. Temporalmente falando, as variáveis físicas e químicas fornecem uma visão pontual da qualidade da água, enquanto que os macroinvertebrados bentônicos, pela sua maior permanência na água e por responderem bem a qualquer distúrbio, fornecem uma avaliação retrospectiva da qualidade da água (Loyola, 2000). 


\section{CONCLUSÕES}

Os indicadores de qualidade do solo utilizados que melhor se prestaram para a diferenciação das práticas agrícolas foram a densidade aparente do solo e o quociente metabólico.

O solo sob plantio direto com rotação de culturas apresentou melhor qualidade física, química e biológica em relação ao cultivo mínimo sem rotação de culturas.

Os solos sob plantio direto tanto no latossolo roxo quanto na terra roxa estruturada, bem como o solo sob o fragmento florestal do latossolo roxo apresentaram teores de biomassa microbiana semelhantes, ao passo que o solo do fragmento florestal situado na terra roxa estruturada foi o que apresentou maior teor de biomassa microbiana. Entretanto, ao se analisar o quociente metabólico, conclui-se que a microbiota sob o plantio direto (nos dois solos analisados) apresenta-se menos estressada que no solo do fragmento florestal situado no latossolo roxo.

A qualidade da água na microbacia do rio Passo Cue piorou da montante para a jusante em função do seu uso agropecuário, sendo isso melhor evidenciado pelos resultados das variáveis físicas, químicas e microbiológicas.

A avaliação da qualidade da água deve ser feita com base na análise conjunta das variáveis físicas, químicas e dos macroinvertebrados bentônicos, tendo em vista a resposta diferenciada desses indicadores em relação à pressão de uso da microbacia. Essa resposta diferenciada foi devido à própria essência dos indicadores, mas também devido à frequiência de amostragem adotada (trimestral), a qual não contempla eventos pluviométricos importantes, nem tampouco todas as descargas pontuais.

O sistema de terraceamento agrícola bastante presente na microbacia, embora não tenha sido avaliado, parece ter contribuído de modo fundamental no controle da poluição difusa, tendo em vista que mesmo com a ausência da mata ciliar na maior parte da 
microbacia e com o manejo agrícola em condições não totalmente adequadas, a qualidade da água em termos absolutos vem se apresentando em patamares relativamente estáveis e em determinados períodos em condições aceitáveis.

A avaliação da saúde da microbacia com base em indicadores de qualidade do solo e água parece constituir-se em metodologia consistente, a qual, entretanto, depende fundamentalmente de um adequado planejamento de monitoramento espacial e temporal em ambos (solo e água). Por fim, essa avaliação deve considerar também a análise de indicadores da escala meso, representados por parâmetros indicativos das condições hidrológicas prevalecentes na microbacia, principalmente no que diz respeito às condições do ecossistema ripário, cujas informações estão também relacionadas com a sustentabilidade. 


\section{REFERÊNCIAS BIBLIOGRÁFICAS}

ALTIERI, M. Agroecologia: bases científicas para uma agricultura sustentável. Guaíba: Agropecuária, 2002. 592p.

ANDERSON, T.H.; DOMSCH, K.H. The metabolic quotient for $\mathrm{CO} 2$ (qCO2) as a specific activity parameter to assess the effects of environmental conditions, such as $\mathrm{pH}$, on the microbial biomass of forest soils. Soil Biology and Biochemistry, v.25, n.4, p.393-395, Abr.1993.

ARCOVA, F.C.S.. Balanço hídrico, características do deflúvio e calibragem de duas microbacias hidrográficas na Serra do Mar, SP. Piracicaba, 1996. 130p. Dissertação (Mestrado) - Escola Superior de Agricultura "Luiz de Queiroz", Universidade de São Paulo.

BARDGETT, R.D.; SAGGAR, S. Effect of heavy metal contamination on the shortterm decomposition of labelled $\left({ }^{14} \mathrm{C}\right)$ in a pasture soil. Soil Biology and Biochemistry, v.26, p.727-733, 1994.

BENASSI, S.F. Estudo das variáveis limnológicas e do processo de autodepuração na descontinuidade serial do ribeirão Bonito. São Carlos, 2002. 120p. Dissertação (Mestrado) - Escola de Engenharia de São Carlos, Universidade de São Paulo.

BINI, L.M. Alguns problemas coma a aplicação de índices de estado trófico em reservatórios. In: WORKSHOP SOBRE GESTÃO AMBIENTAL DE RESERAVTÓRIOS HIDRELÉTRICOS. MONITORAMENTO E AVALIAÇÃO DA QUALIDADE DA ÁGUA EM RESERVATÓRIO, 1., São Paulo, 1999. São Paulo: CESP, 1999. p. 31-43. (Série Divulgação e Informação, 237).

BRADY, N.C. Natureza e propriedade dos solos. 6.ed. Rio de Janeiro: Bertrand, 1983. $647 \mathrm{p}$.

CÂMARA, C.D. Efeitos do corte raso do eucalipto sobre o balanço hídrico e a ciclagem de nutrientes em uma microbacia experimental. Piracicaba, 1999. 87p. Dissertação 
(Mestrado) - Escola Superior de Agricultura Luiz de Queiroz, Universidade de São Paulo.

CAMARGO, O.D.de; MONIZ, A.C.; JORGE, J.A.; VALADARES, J.M.A.S. Métodos de análise química, mineralógica e física de solo do Instituto Agronômico de Campinas. Campinas: IAC, 1986. (IAC. Boletim Técnico, 106).

CHAVES, H.M.L. É possível recuperar rios assoreados? Ação Ambiental, v.1, n. 3, p.17-19, jan. 1999.

CONSELHO NACIONAL DO MEIO AMBIENTE. Resolução no 20 de 18 de junho de 1986: classifica as águas doces, salobras e salinas. Brasília, 1986.

CONWAY, G.R. Sustainability in agricultural development: trade-offs wth productivity, satability and equitibililty. Journal of Farming Systems Research Ext., v. 4, n.2, p.1-14, 1994.

DERPSCH, R.; ROTH, H.C.; SIDIVAS, N.; KOPKE, U. Controle de erosão no Paraná, Brasil: sistemas de cobertura do solo, plantio direto e preparo conservacionista do solo. Eschoborn: Dt. Ges. fur Techn. Zusammenarbeit (GTZ). Gmbh, 1991.

DIEGUES, A.C.S. O mito moderno da natureza intocada. São Paulo: NUPAUB, Universidade de São Paulo, 1994. 163p.

DUMANSKI, J., PIERI, C. Land quality indicators: research plan. Agriculture, Ecosystems \& Environment, v. 81, p.155-162, 2000.

ESWARAN, H.; FRIEDRICH, H.B.; SURENDER, M.V. Resource management domains: a biophysical unit for assessing and monitoring land quality. Agriculture, Ecosystems \& Environment, v.81, p.155-162, 2000.

GLIESSMAN, S. R. Agroecologia: processos ecológicos em agricultura sustentável. Porto Alegre: UFRGS, 2000. 653p.

GONÇALVES, J.L. M; STAPE, J.L. Conservação e cultivo de solos para plantações florestais. Piracicaba: IPEF, 2002. 498p.

GREGORY, S.V.; SWANSON, F.J.; McKEE, W.A.; CUMMINS, K. W. An ecosystem perspective of riparian zones. BioScience, v.41, n.8, p.540-551, 1991.

GROFFMAN, P.M.; McDOWELL, W.H.; MYERS, J.C. MERRIAM, J.L. Soil 
microbial biomass and activity in tropical ripariam forests. Soil Biology \& Biochemistry, v.33, p.1339-1348, 2001.

HANSEN, J.W. Is agricultural sustainability a useful concept? Agricultural Systems, v.50, p.117-143, 1996.

ISLAM, K.R.; WEIL, R.R. Soil quality indicator properties in mid-Atlantic soils as influenced by conservation management. Journal of Soil and Water Conservation, v.55, p.69-78, Jan./Mar. 2000.

JENKINS, K.D.; SANDERS, B.M. Monitoring with biomarkers: a multitiered framework for evaluating the ecological impacts of contaminants. In: McKENZIE, D.H.; HYATT, D.E.; McDONALD, V.J. (Ed.). Ecological indicators. New York: Elsevier Applied Science, 1992. v.2, p.1279-1293.

JOLLY, I.; CAITCHEON, G.; DONNELlY, T.; HAFNER, S. Physical and chemical indicators of water quality. In: WALKER, J.; REUTER, D.J. (Ed.). Indicators of Catchment health: a technical perspective. Melbourne: CSIRO, 1996. p.131-141.

KARLEN.D.L.; WOLLWNHAUPT, N.C.; ERBACH, D.C.; BERRY, E.C.; SWAN, J.B.; EASH, N.S.; JORDAHL, J.L. Crop residue effects on soil quality following 10-years of no-till corn. Soil Tillage Residue, v. 31, p.149-167, 1994.

KENNEDY, A.C.; SMITH, K.L. Soil microbial diversity and the sustainability of agricultural soils. Plant and Soil, v.170, p.75-86, 1995.

LIMA, W.P. Função hidrológica da mata ciliar. In.: SIMPÓSIO SOBRE MATA CILIAR, São Paulo, 1989. Anais. São Paulo:Instituto de Botânica, 1989. p.11-15.

LIMA, W. P.. Hidrologia florestal aplicada ao manejo de bacias hidrográficas. Piracicaba: ESALQ, Depto. Ciências Florestais, 1996. 318p.

LIMA, W. P.. A microbacia e o desenvolvimento sustentável. Ação Ambiental, v.1, n. 3, p.20 - 22, jan. 1999.

LIMA, W. P.; ZAKIA, M. J. B. Monitoramento de bacias hidrográficas em áreas florestadas. Série Técnica IPEF, v.10, n.29, p.11-21, 1996.

LIMA, W. P. \& ZAKIA, M. J. B. Indicadores hidrológicos em áreas florestais. Série Técnica IPEF, v.12, n.31, p.53 - 64, abr. 1998. 
LIMA, W.P.; ZAKIA, M.J.B. Rede de monitoramento ambiental em microbacias: indicadores hidrológicos do manejo sustentável de plantações florestais. Piracicaba: IPEF, 1997. 26p. (Relatório Anual)

LIMA, W.P.; ZAKIA. M.J.B. Hidrologia de matas ciliares. In: RODRIGUES, R.R.; LEITÃO FILHO, H.F. (Ed.). Matas ciliares: conservação e recuperação. São Paulo: Editora da Universidade de São Paulo,Fapesp, 2000. p. 33-44.

LOYOLA, R.G.N. Atual estágio do IAP no uso de índices biológicos de qualidade. In: SIMPÓSIO DE ECOSSISTEMAS BRASILEIROS: Conservação, 5., Londrina, 2000. Anais. Londrina: Conservação e Duna, 2000. p.46-52.

LOWRANCE, R.; TODD, R.; FAIL JUNIOR., J.; HENDRICKSON JUNIOR., O.; LEONARD, R.; ASMUSSEN, L. Riparian forests as nutrient filters in agricultural watersheds. BioScience, v.34, n. 6, p. 374-377, 1984.

MASERA, O.; ASTIER, M.; RIDAURA, S. L. Sustentabilidad y manejo de recursos naturales: el marco de evaluación (MESMIS). Mexico: Mundi-Prensa,1999. 107p.

MELLO, M.H.A.; PEDRO JUNIOR, M.J.; LOMBARDI NETO, F. Manual técnico de manejo e conservação de solo e água. Campinas: CATI, 1994.v.2.

MERRY, R.H. Chemical indicators of soil health. In: WALKER, J.; REUTER, D.J. (Ed.). Indicators of Catchment health: a technical perspective. Melbourne: CSIRO, 1996. p.109-119.

MERTEN, G.H. Impacto da mecanização do solo. In: In: SIMPÓSIO SOBRE IMPACTO AMBIENTAL POR USO AGRÍCOLA DO SOLO, Campinas, 1994. Anais. Campinas: Instituto Agronômico, 1994. p. 47-58. ( IAC. Documentos, 49).

ODUM, E.P. Ecologia. Rio de Janeiro: Guanabara, 1988.

OLIVEIRA, P.A.V. de. Manual de manejo e utilização de dejetos de suínos. Concórdia: Embrapa, CNPSA, 1993.188p. (Documentos, 27).

PAPENDICK, R.; PARR, J.F. Soil quality: The key to a sustainable agriculture. American Journal of Alternative Agriculture, v.7, n.1/2, p.2-3, 1992.

PARTON, W.J.; SANFORD, R.L.; SANCHEZ, P.A.;NSTEWART, J.W.B. Modeling soil organic matter dynamics in tropical soils. In.: COLEMAN, D.C. OADES, J.M.; 
UEHARA, G. (Ed.). Dynamics of soil organic matter in tropical ecosystems. Honolulu: Niftal Project, 1989.

PIMENTEL-GOMES, F. Curso de estatística experimental. 14.ed. Piracicaba: ESALQ, 2000. 477p.

POGGIANI, F.; LIMA, W.P.; BALLONI, E.A., NICOLELLO,N. Respiração edáfica em plantações de coníferas e folhosas exóticas em área de cerrado do estado de São Paulo. IPEF, v.14, p.129-148, 1977.

PORTO, R.M. Hidráulica básica. São Carlos: USP, EESC, 1998.

POWLSON, D.S.; BROOKES, P.C.; CHRISTENSEN, B.T. Measurement of soil microbial biomass provides an early indication of changes in total soil organic matter due to straw incorporation. Soil biology and Biochemistry, v.19, p.159-164, 1987.

PRIMAVESI, A. A erosão. São Paulo: Melhoramentos, 1952.

PRABHU, R.; COLFER, C.J.P.; VENKATESWARLY, P.; TAN, L.C.; SOEKMADI, R.; WOLLENBERG, E. Testing criteria and indicators for the sustainable managment of forests: phase I, final report. Bogor: CIFOR, 1996. 217p.

ROCHA, J.S.M. Manual de manejo integrado de bacias hidrográficas. Santa Maria: Universidade Federal de Santa Maria, 1991.

SILVA, R.R da. Qualidade do solo em função de diferentes sistemas de manejo na região Campos das Vertentes, bacia alto do rio Grande-MG. Lavras, 2001. 96p. Dissertação (Mestrado)-Universidade Federal de Lavras.

SOUZA, A.L.L. de. Meio ambiente e desenvolvimento sustentável: uma reflexão crítica. Belém: FCAP, Serviço de Documentação e Informação, 1996. 50p.

SPARLING, G.P. Ratio of microbial biomass carbon to soil organic carbon as a sensitive indicator of changes in soil organic matter. Australian Journal of Soil Research, v.30, p.195-207, 1992.

TIBAU, A.O. Matéria orgânica e fertilidade do solo. 2.ed. São Paulo: Nobel, 1977.

TILMAN, D. Global environmental impacts of agricultural expansion: The need for sustainable and efficient practices. Proceedings of the National. Academy. Science of the USA, v.96, p.5995-6000, 1999. 
VALENTE, O.F. Manejo de bacias hidrográficas. Ação Ambiental, v.1, n.3, p.5-6, jan. 1999.

VANCE, E.D.; BROOKES, P.C; JENKINSON, D.S. An extraction method for measuring soil microbial biomass C. Soil Biology \& Biochemistry, v.19, p703-707, 1987.

VIEIRA, L.S. Manual da ciência do solo. São Paulo: Agronômica Ceres, 1975.

WALKER, J.; REUTER, D.J. Indicators of catchment health: a technical perspective. Melbourne: CSIRO, 1996. 174p.

WALKER, J.; ALEXANDER, D.; IRONS, C.; JONES, B.; PENRIDGE, H.; RAPPORT, D. Catchment health indicators: an overview. In: WALKER, J.; REUTER, D.J. Indicators of Catchment health: a technical perspective. Melbourne: CISRO, 1996. cap.1, p. 3-18.

ZAKIA, M.J.B. Identificação e caracterização da zona ripária em uma microbacia experimental: implicações no manejo de bacias hidrográficas e na recomposição de florestas. São Carlos, 1998. 98p. Tese (Doutorado) - Escola de Engenharia de São Carlos, Universidade de São Paulo. 